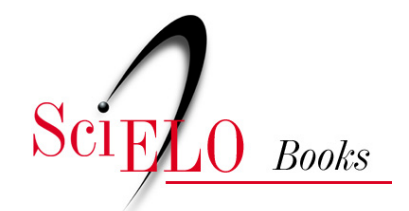

\title{
Mulheres em foco
}

construções cinematográficas brasileiras da participação política feminina

\section{Danielle Tega}

\section{SciELO Books / SciELO Livros / SciELO Libros}

TEGA, D. Mulheres em foco: construções cinematográficas brasileiras da participação política feminina [online]. São Paulo: Editora UNESP; São Paulo: Cultura Acadêmica, 2010. 149 p. ISBN 978-85-7983-123-2. Available from SciELO Books <http://books.scielo.org>.

\section{(2)(1)(2)}

All the contents of this chapter, except where otherwise noted, is licensed under a Creative Commons Attribution-Non Commercial-ShareAlike 3.0 Unported.

Todo o conteúdo deste capítulo, exceto quando houver ressalva, é publicado sob a licença Creative Commons Atribuição Uso Não Comercial - Partilha nos Mesmos Termos 3.0 Não adaptada.

Todo el contenido de este capítulo, excepto donde se indique lo contrario, está bajo licencia de la licencia Creative Commons Reconocimento-NoComercial-CompartirIgual 3.0 Unported. 


\section{MULHERES}

\section{EM FOCO}

CONSTRUÇÕES

CINEMATOGRÁFICAS

BRASIILEIRAS DA PARTICIPAÇÃO POLIITICA FEMININA

\section{DANIELLE TEGA}


MULHERES EM FOCO 
CONSELHO EDITORIAL ACADÊMICO

Responsável pela publicação desta obra

Darlene Aparecida de Oliveira Ferreira

João Carlos Soares Zuin

Maria Ribeiro do Valle 


\title{
DANIELLE TEGA
}

\author{
MULHERES \\ EM FOCO \\ CONSTRUÇÕES \\ CINEMATOGRÁFICAS \\ BRASILEIRAS DA \\ PARTICIPAÇÃO POLÍTICA \\ FEMININA
}

CULTURA

$\frac{\text { ACADÊMICA }}{\varepsilon d i t o n a}$ 
(C) 2010 Editora UNESP

\section{Cultura Acadêmica}

Praça da Sé, 108

01001-900 - São Paulo - SP

Tel.: (0xx11) 3242-7171

Fax: (0xx11) 3242-7172

www.editoraunesp.com.br

feu@editora.unesp.br

CIP - Brasil. Catalogação na fonte

Sindicato Nacional dos Editores de Livros, RJ

$\mathrm{T} 258 \mathrm{~m}$

Tega, Danielle

Mulheres em foco: construções cinematográficas brasileiras da participação política feminina / Danielle Tega. - São Paulo : Cultura Acadêmica, 2010.

\section{Anexos}

Inclui bibliografia

ISBN 978-85-7983-123-2

1. Mulheres no cinema - Brasil. 2. Cinema - Aspectos políticos - Brasil. 3. Cinema e história - Brasil. 4. Filmes históricos - Brasil. 5. Brasil - História - Revolução, 1964 - Participação feminina. I. Título.

$11-0119$.

CDD: 791.430981

CDU: 791(81)

Este livro é publicado pelo Programa de Publicações Digitais da Pró-Reitoria de Pós-Graduação da Universidade Estadual Paulista "Júlio de Mesquita Filho" (UNESP)

Editora afiliada:
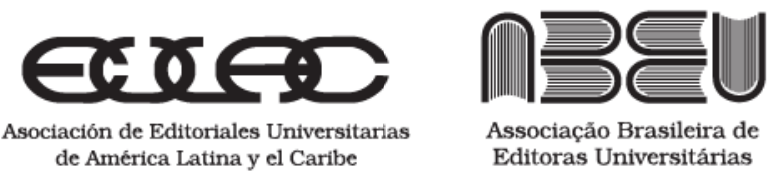
Para minha mãe.

E à memória de meu pai. 



\section{Agradecimentos}

Gostaria de agradecer à professora doutora Eliana Maria de Melo Souza por suas sugestões sensíveis e sempre apuradas, mas principalmente pela amizade e acolhida. À professora doutora Lucila Scavone, pelas indicações pertinentes que contribuíram com esta pesquisa. À professora doutora Maria Lygia Quartim de Moraes, minha inspiração nas trilhas feministas, por ter-me incentivado a seguir na vida acadêmica.

Às minhas queridas amigas, Aline, Carla, Keyth, Tatiana e Michele, mulheres incríveis que me dão força e me fazem rir mesmo em tempos difíceis! À Ana Cláudia, por todas as nossas conversas. Aos três efes maravilhosos que conheci no mestrado: Fagner, amigo marxista das divertidas conversas e dos sérios debates nas estradas para Araraquara; Fernanda, amiga feminista das infinitas trocas de mensagens com discussões sobre o tema; e Frederico, estimado amigo, por todo carinho, apoio e incentivo. Ao Davi, pela amizade de anos e pela torcida incansável, e à Patrícia, uma quase irmã que não deixou que a travessia desta pesquisa fosse solitária, me oferecendo palavras que confortavam e animavam.

À minha mãe, que sempre me incentivou a estudar, apoiando minhas decisões incondicionalmente, e ao meu irmão, figura rara, pelos momentos felizes que passamos juntos! Agradeço especialmen- 
te meu companheiro amado, Luís Antonio, por estar sempre ao meu lado e pelo amor e paciência a mim dedicados.

Por fim, agradeço à Fundação de Amparo e Pesquisa do Estado de São Paulo (Fapesp) pela bolsa concedida, a qual possibilitou que eu me dedicasse integralmente aos estudos que originaram este livro. 
No fundo, tudo dependerá do modo pelo qual o passado será referido no presente; se permanecemos no simples remorso ou se resistimos ao horror com base na força de compreender até mesmo o incompreensivel.

(Adorno, 2006, p.46) 



\section{SUMÁRIO}

Introdução 13

1 Tecendo os fios: memória, feminismo e cinema 21

2 Vozes femininas em cena 69

3 Outras vozes nos conflitos da memória 101

Considerações finais 131

Referências bibliográficas 137

Anexos 147 



\section{INTRODUÇÃO}

Esta seção introdutória poderia receber o subtítulo de trajetória. Apontar questões relevantes a esta pesquisa, seu objeto de estudo e suas preocupações teóricas; descrever brevemente os capítulos, apresentando temas a serem desenvolvidos; indicar a fonte dos fios que tramam este livro: são atividades que remetem às inquietações iniciais, aos primeiros estudos e leituras realizadas, aos caminhos posteriormente percorridos, que compuseram, de diferentes maneiras, a tessitura ora exposta.

A preparação deste livro foi marcada por dúvidas e desafios. Durante esse período, algumas pessoas questionavam: Mas o que você realmente quer pesquisar? O feminismo brasileiro? A ditadura militar? As representações de gênero no cinema? O debate memória versus esquecimento? Eram perguntas que, não poucas vezes, desanimavam essa empreitada. Não seria, então, possível trabalhar com esses assuntos ao mesmo tempo? É certo que, de forma excludente, cada um desses temas poderia dar origem a diferentes livros. Mas também é certo que minha intenção trilhava um caminho em que esses assuntos se entrecruzavam - e, se me parecia trabalhoso cada tema em si, parecia-me tarefa ainda mais árdua separá-los. Tento explicar melhor.

Comecemos pela ditadura militar no Brasil. Iniciei meus estudos sobre esse período ao participar, na graduação, da pesquisa Do- 
cumentos e memórias da repressão militar e da resistência política: Brasil, 1964-1982, ${ }^{1}$ coordenada pela professora Maria Lygia Quartim de Moraes no Instituto de Filosofia e Ciências Humanas da Unicamp. As informações sobre o processo histórico e o golpe civil- militar, a participação política dos estudantes e de outros grupos de resistência, ${ }^{2}$ como a opção pela luta armada: conhecer melhor a forma pela qual uma geração lutou contra a repressão imposta pelo Estado era conhecer um lado da história que pouco se comentava no meio em que eu até então participava antes de ingressar na universidade. E, mesmo nesta, a não ser nos institutos onde havia grupos de estudos sobre esse tema, pouco se sabia a respeito das torturas cometidas e das arbitrariedades impostas, como a censura e a proibição de reuniões no período anterior.

Como uma parte fundamental da história do país fica tão esqueci$d a$ ? Como examinar o processo pelo qual a ditadura militar, quando abordada em aulas do ensino médio e em discussões nos jornais, transforma-se em um período patológico da história do Brasil, em algo que faz parte de um passado parece não mais pertencer a um país, agora, democrático (como se os desmandos cometidos pelas

1 Essa pesquisa buscou sistematizar os arquivos do projeto Brasil: Nunca Mais, cujos arquivos completos, que consiste na compilação e cópia dos processos arquivados pelos Superiores Tribunais e Auditorias Militares, realizadas de maneira clandestina, podem ser encontrados no Arquivo Edgard Leuenroth, do Instituto de Filosofia e Ciências Humanas da Universidade Estadual de Campinas (Unicamp). Trata-se de um trabalho organizado em 12 tomos, com informações sobre os grupos formados pelos militantes políticos, as torturas, a relação de mortos e de agentes dos aparelhos repressivos, depoimentos, laudos, obituários etc.

2 Utilizo o termo resistência no sentido proposto por Marcelo Ridenti, que abarca tanto as políticas defensivas quanto os projetos ofensivos dos grupos guerrilheiros. Mas o autor pondera que "se parece apropriado qualificar a luta das esquerdas como de resistência, isso não deve significar um pacto com o que se poderia chamar de ideologia da resistência democrática". Cf. Ridenti, Resistência e mistificação da resistência armada contra a ditadura: armadilha para os pesquisadores. In: Reis; Ridenti; Motta, 2004, p.57-58. Ver também: Ridenti, 2007. 
classes dominantes de então ficassem restritos aos anos do regime autoritário e não fizessem mais parte da realidade brasileira)? Como compreender o modo pelo qual os debates na mídia sobre esse tema ponderam as ações dos militares e de seus aliados em relação a seus oponentes?

Retornando às leituras que fiz sobre a ditadura militar brasileira, outro assunto que me despertou atenção foi a participação política feminina. Mulheres participaram da resistência à ditadura de diferentes formas: no movimento estudantil, na luta armada, nas atividades realizadas no exílio, na formação de comitês pela Anistia. Ou nos grupos de bairro, com o movimento de mulheres, que, ao lutar por melhores condições (como creches, contra a carestia), procuram combater a lógica excludente da política econômica ditatorial. Elas, de diferentes maneiras, estavam em cena naquele momento. Momento que, além do movimento de mulheres, presenciou a segunda onda do movimento feminista. Novas questões foram postas, convenções de feminilidade e masculinidade discutidas, comportamentos questionados. Desse modo, penso que o estudo sobre a ditadura militar no Brasil é uma situação estritamente ligada à questão das mulheres e ao ressurgimento do feminismo.

Munida dessas percepções, escolhi o cinema como objeto de estudo na tentativa de, a princípio, verificar o modo pelo qual a resistência política à ditadura militar foi representada no período a ela posterior, dando destaque à participação feminina. A análise fílmica possibilitaria observar quais elementos estariam presentes em cena para retratar tal questão, e os estudos de gênero permitiriam debater de que forma as relações sociais entre os sexos eram abordadas nos filmes selecionados.

Mas ainda faltava um fio condutor para minha pesquisa, pois não era meu interesse fazer um exame apenas descritivo. E é nesse ponto que encontro os estudos da memória - e reencontro minhas inquietações iniciais. Afinal, se há pouco conhecimento sobre a ditadura militar no Brasil e se a percepção sobre as consequências desse período para as relações sociais no país é defasada, é porque uma versão da história parece ter mais força. E isso remete a um proble- 
ma político, pois quem detém o poder sobre os eventos passados também o detém sobre o momento presente e, com isso, é capaz de englobar também o futuro. Trata-se, portanto, de compreender não apenas como a resistência à ditadura é representada, mas, sobretudo, como esse passado é reconstruído nas diversas formas em que pode ser materializado. Desse modo, articula-se o resgate do passado aos conflitos sociais do presente, mostrando os interesses de certas classes em apoiar ou se opor a tal reconstrução.

Isso permite afirmar que as memórias sociais não são fixas, mas construídas, e estão em permanente conflito. As seleções realizadas sobre o que mostrar e como mostrar relaciona-se às lutas pela apropriação do passado, possibilitando encarar as interpretações feitas no presente como dinâmicas e capazes de oferecer elementos à transformação social.

Essas considerações também revelam outro ponto importante: não se trata apenas de fazer um estudo sobre as mulheres e sobre as feministas, mas sim de realizá-lo pela perspectiva feminista, considerando que esta trabalha com elementos fundamentais na luta em torno da memória e pelo reconhecimento de histórias esquecidas. Nesse sentido, procuro privilegiar os pontos onde se cruzam os estudos da memória e o pensamento feminista, visto que este atinge profundamente as necessidades de um resgate histórico ao denunciar o esquecimento de reivindicações, lutas e ações das mulheres.

Trabalhar a memória por uma perspectiva feminista não é uma tarefa que pode ser isolada de um contexto político específico. Dessa forma, mesmo que este livro apresente algumas reflexões de caráter geral, o objetivo é fazê-las a partir de um lugar particular: examinar a reconstrução da militância feminina na luta contra a ditadura militar em filmes brasileiros produzidos após a promulgação da Lei da Anistia, verificando os paradoxos e tensões presentes nesses filmes que, cada qual à sua maneira, ressignificam convenções de feminilidade e, por relação, de masculinidade -, e qual a consequência dessas escolhas para o modo pelo qual a memória desse período é manifestada.

Cabe ressaltar que não é minha intenção realizar um tipo de análise fílmica como fariam pesquisadores (as) profissionais de cinema. 
No entanto, algumas armadilhas estão presentes quando se trabalha com material cinematográfico, e certos conhecimentos sobre este devem ser levados em consideração na tentativa de desviar desses perigos. Sobre esse assunto, Francis Vanoye e Anne Goliot-Lété (2008) alertam que uma das emboscadas "consiste em ler num filme toda a sociedade e a história do tempo, presentes, passadas e principalmente futuras"; e ponderam que não se deve confundir "certas formas cinematográficas com certas funções", como o fato de conceber os documentários em oposição às ficções, portadores da função de testemunhar o real. Para escapar dessas suposições, convém expor a reflexão de Jacques Aumont (1995, p.100) quando afirma que "o cinema tem de fato esse poder de ausentar o que nos mostra, [pois] a cena registrada já passou e porque se desenvolveu em outro lugar que não na tela onde ela vem se inscrever". Como "representante e representado são ambos fictícios", o autor conclui que "qualquer filme é um filme de ficção".

E para não travar polêmica sobre certos filmes serem ou não obras de arte ou apenas produtos da indústria cultural, amparo-me na observação de Fredric Jameson (1992), quando pontua que qualquer obra de cultura é resultado de um tempo histórico real que cabe ao crítico desvendar. Como acrescenta Célia Tolentino (1997, p.VI) a esse respeito,

Mesmo que seja na manifestação artística mais massificada e comercial, é possível encontrar questões importantes para pensar o mundo moderno e as formas de entendimento da vida que, frequentemente, anseiam por um sentido da relação entre homem e natureza, entre homem e tempo histórico.

Procuro trabalhar sob esse prisma, mas este aponta que são muitos os filmes brasileiros que abordam a ditadura militar. Se considerarmos os filmes realizados durante o período que se estende do golpe militar à publicação da anistia, podem ser citados $O$ desafio (no Brasil depois de abril); Fome de amor; Terra em transe, entre diversos outros. Após a anistia, há Prá frente, Brasil; O bom burguês; Nunca 
fomos tão felizes; etc. Na fase conhecida como "cinema da retomada", são exemplos O que é isso, companheiro?; Lamarca; Alma corsária. E nessa última década há Quase dois irmãos; $O$ ano em que meus pais saíram de férias; Batismo de sangue; Zuzu Angel; Vlado - 30 anos depois etc.

Dado o grande número de filmes sobre o tema, cada qual proporcionando diferentes tipos de leitura e interpretação, destaco que o critério de seleção dos filmes estudados neste livro não obedece a parâmetros de representatividade ou de qualidade, mas sim o interesse em apresentar algumas das possíveis e divergentes modalidades de manifestação da memória no cinema, dando destaque para a forma pela qual essa "memória cinematográfica" trabalha a participação política feminina e as relações de gênero. Nesse sentido, mesmo que sirva como justificativa o recorte temporal que possibilita o estudo da memória sobre o período ditatorial (filmes realizados após 1979), mesmo que os filmes escolhidos façam reconstruções de situações-limite da resistência: ainda assim, talvez a seleção dos dois filmes aqui examinados insira-se naquilo que Antonio Candido (1969, p.23) chamou de "dose necessária de arbítrio".

O foco deste livro é o filme Que bom te ver viva, dirigido por Lúcia Murat e lançado em 1989, que mistura documentário e ficção para contar a história de mulheres que participaram da luta contra a ditadura civil-militar. Para fazer um contraponto, procurando observar de que modo o cinema ficcional trabalha o mesmo período, optei por estudar algumas sequências do filme O que é isso, companheiro?, dirigido por Bruno Barreto e lançado em 1997. Por serem gêneros diferentes, penso que podem contribuir na observação de diferentes formas para se manifestar a memória de um período, além de oferecer elementos diversos para se compreender as construções das relações de gênero.

O primeiro capítulo deste livro apresenta as inspirações teóricas, fazendo uma reflexão sobre os estudos da memória, o pensamento feminista e o cinema. Seu principal objetivo é mostrar as afinidades no entrecruzamento entre memória e feminismo, bem como a possibilidade de tratá-los como práticas e teorias emancipatórias. Desse 
modo, enfatiza a importância dos estudos da memória para a compreensão da resistência política à ditadura militar e dos conflitos ao redor das reconstruções do passado. Resgata, também, o surgimento do pensamento feminista norte-americano e europeu, e dá destaque para o pensamento feminista brasileiro e a relação que este estabelece na luta contra a ditadura. Ao tratar o cinema como "manifestação da memória", este capítulo também apresenta considerações sobre os estudos feministas e de gênero em relação ao cinema, fazendo um debate entre as principais questões teóricas do assunto.

No segundo capítulo, inicio um estudo do filme Que bom te ver viva, considerado como uma manifestação de questões que ficaram em segundo plano no período de resistência à ditadura, como as relacionadas à subjetividade. Nesse sentido, parece haver pertinência em articulá-lo ao pensamento feminista brasileiro e suas formas de atuação nos anos 1980 (período de produção e lançamento da película), marcadas por questionamentos atentos à sexualidade e à violência - temas cobertos pelo filme. Sustento a ideia de que a tortura, além de ser um ato brutal contra qualquer militante, é também uma violência de gênero, carregada de ideologia patriarcal ao ser pensada e posta em prática.

O terceiro capítulo é composto por uma discussão de determinadas cenas do filme $O$ que é isso, companheiro?, escolhidas de modo que possam apresentar questões referentes ao debate em torno da memória. O pressuposto é de que os limites que apresenta para a compreensão de uma experiência política são consequências da forma pela qual o filme trabalha as relações de gênero. Num segundo momento, retorno ao filme de Lúcia Murat para, a partir das novas ponderações realizadas, verificar outros paradoxos e tensões presentes no documentário.

Por fim, escrevo algumas reflexões que, espero, não sejam finais, na esperança que este livro apresente alguns rastros que possam ser resgatados e reinterpretados em pesquisas futuras, dando continuidade ao debate e à luta pelo não esquecimento. 



\section{1 \\ TECENDO OS FIOS: \\ MEMÓRIA, FEMINISMO E CINEMA}

\section{Entre lembranças e esquecimentos: memória e ditadura militar}

Em fevereiro de 2009, meses antes de se completarem os 30 anos da Lei da Anistia, o editorial do jornal Folha de S. Paulo usou o termo ditabranda para caracterizar de forma amena o repressivo regime político instaurado a partir do golpe civil-militar de 1964, e que perdurou até 1985. Esse despautério explicita uma importante questão sociológica, que é a maneira pela qual o passado é narrado no presente - e como esta implicação interfere nas práticas futuras.

Não se trata apenas da memória construída sobre os acontecimentos de uma sociedade, mas da disputa em torno dessa construção, pois apropriar-se desse passado, monopolizá-lo, torna-se um objetivo àqueles que, no presente, buscam controle e poder sobre o futuro. Se no Manifesto comunista, Karl Marx e Friedrich Engels (1998) já denunciavam que as ideias dominantes em uma época são as ideias da classe dominante, é nos textos de Walter Benjamin (1985) que encontramos um apelo para a recuperação das ideias daqueles que foram dominados, um agravo pelas versões alternativas à história dominante e oficial. Esse embate entre possíveis versões a serem resgatadas encontra-se conjuntamente com suas reflexões sobre as tra- 
mas da memória e do esquecimento. Seguindo trilhas próximas às benjaminianas, Theodor Adorno (2000) também apresenta questões fundamentais ao evidenciar a necessidade de elaboração do passado (traumático).

Voltemos à discussão sobre a ditadura militar no Brasil (19641985), que foi caracterizada pela censura e repressão, pela violência desmedida imposta pelo Estado, pelas mortes e pelos "desaparecimentos": não há dúvidas de que se trata de um período traumático, no sentido em que o termo é utilizado por Luiz Felipe de Alencastro (2006) e Márcio Seligmann-Silva (2003b). Este, tendo como foco a literatura do trauma e baseando-se nos escritos de Walter Benjamin e Sigmund Freud, afirma que a história do trauma é a história de um choque violento e de um desencontro com o real: a experiência traumática é "aquela que não pode ser totalmente assimilada enquanto ocorre", marcada pela "incapacidade de simbolizar o choque" (idem, p.52-53). Luiz Felipe de Alencastro completa que há, na sociedade brasileira, "traumas históricos fundamentais que passam pelo processo alternado de esquecimento e rememoração para constituir a nossa contemporaneidade”. Em longo prazo, o autor cita o drama do tráfico negreiro e do escravismo; em médio e curto prazos, o drama da ditadura militar.

Dada a relevância das reflexões de Benjamin e Adorno para se pensar as questões da memória, do trauma e da elaboração do passado numa perspectiva que resgate outras histórias possíveis além das dominantes, utilizo algumas páginas deste livro para esboçar breves considerações sobre as ideias desses dois autores. Nessa discussão, apoio-me nas leituras e interpretações que Jeanne Marie Gagnebin e Márcio Seligmann-Silva fazem dos pensadores alemães.

Os períodos posteriores ao trauma são momentos que apresentam dificuldades em exercitar a memória, principalmente em sociedades que assumem convicções opostas aos preceitos do estado de exceção, como a brasileira. Após 30 anos da promulgação da Lei da Anistia, a forma como diferentes grupos enfrentam a questão do passado ditatorial deixa claro que se trata de um assunto ainda não resolvido. Por um lado, pesquisadores, ex-militantes, organizações 
de direitos humanos e outras esferas clamam pela abertura dos arquivos da ditadura militar e pelo julgamento dos torturadores. Por outro, militares e setores conservadores da sociedade consideram essas demandas como revanchistas, protestam contra as indenizações pagas aos ex-militantes e familiares de militantes mortos e 'desaparecidos', e insistem em não tocar nesse passado nebuloso. ${ }^{1}$

Diante desse quadro, os estudos sobre o trabalho da(s) memória(s) e seus conflitos são importantes ferramentas para o entendimento do modo pelo qual o passado é recuperado e interpretado. Como o entendimento dessas questões depende da compreensão dos termos de Benjamin e Adorno, vamos a eles primeiro.

\section{As tramas da memória: em busca de um resgate emancipador}

A teoria da memória de Walter Benjamin está entrecruzada à sua teoria da experiência que, por sua vez, tem origem literária - tanto em suas leituras proustianas quanto em seus estudos sobre a decadência da narração. Em seu livro Charles Baudelaire: um lírico no auge do capitalismo (2004), o autor apresenta a diferença entre a mera lembrança e a memória: esta, capaz de recuperar a aura do passado, guarda uma dimensão adequada para salvá-lo. Partindo da leitura de Em busca do tempo perdido, Benjamin recupera os dois tipos de memória já expostos por Marcel Proust em sua obra. A memória voluntária, sujeita aos apelos da atenção e à tutela do intelecto, pauta-se pela reprodução das imagens pretéritas e é determinada pela

1 Trata-se, porém, de uma discussão que não pode ser descrita apenas como um confronto de grupos divergentes entre si e estanques. Há discordâncias quando o próprio governo trata desse tema: enquanto o Ministro da Justiça Tarso Genro e o Ministro da Secretaria Especial de Direitos Humanos Paulo Vannuchi declararam seu apoio a tais reivindicações, o Ministro da Defesa Nelson Jobim foi energicamente contrário a elas. No caso de ex-militantes, há situações em que retomar esse passado ou falar sobre ele torna-se sinal de autoflagelação. 
vontade de quem lembra; não guarda informações ou traços sobre o passado, fazendo com que o esforço para evocá-lo seja deliberadamente inútil. Já a memória involuntária, encontrada fora do âmbito do intelecto, é caracterizada pelo assalto das imagens e sensações do passado; trata-se de uma memória que não responde à vontade de quem quer lembrar.

Caracterizando melhor as diferenças entre a memória voluntária e a memória involuntária, Benjamin reporta-se a Sigmund Freud e ao estudo do consciente. Para o psicanalista, a função do consciente é agir como proteção contra os diversos estímulos, atuando como amortecedor de choques; outros sistemas psíquicos, que não o da consciência, teriam a função de acumular os "traços permanentes como fundamento da memória". Benjamin recupera essas observações freudianas e as traduz em termos proustianos, relacionando à memória involuntária aquilo que não teve a intervenção do consciente e que, portanto, seria portador de experiência; e à memória voluntária aquilo que foi conscientemente vivido. Nas palavras do autor:

O fato de o choque ser assim amortecido e aparado pelo consciente emprestaria ao evento que o provoca o caráter de experiência vivida em sentido restrito. [...] Quanto maior é a participação do fator do choque em cada uma das impressões, tanto mais constante deve ser a presença do consciente no interesse em proteger contra os estímulos; quanto maior for o êxito com que ele operar, tanto menos essas impressões serão incorporadas à experiência e tanto mais corresponderão ao conceito de vivência. (Benjamin, 2004, p.111)

Essas considerações aludem às distinções que o autor faz entre "experiência vivida" (Erlebnis)e "experiência coletiva" (Erfahrung). A primeira está vinculada à sociabilidade do indivíduo privado, isolado, pertencente a um mundo cujas informações precisam ser assimiladas às pressas e cujos efeitos rogam-se imediatos. Já a "experiência coletiva" refere-se a uma tradição viva, capaz de constituir uma conexão entre aquilo que ficou escondido no passado e o presente. Nesse âmbito, as recordações voluntárias e involuntárias dei- 
xam de ser mutuamente exclusivas, pois "onde há experiência no sentido estrito do termo, entram em conjunção, na memória, certos conteúdos do passado individual com outros do passado coletivo" (idem, p.107).

É irrelevante acrescentar que a questão perturbadora para Benjamin não é outra senão a violência das transformações da sociedade capitalista, a qual exacerba a atrofia da experiência em função da vivência. ${ }^{2}$ Essa debilidade é percebida na literatura a partir da crise da narração e sua substituição pelas novas formas de contar, como o romance. A obtenção de uma memória comum, antes transmitida através das histórias contadas de geração em geração - como no caso dos contistas e narradores, que tinham como fonte a "experiência coletiva” - é destruída pelas contradições do capitalismo avançado, e tem como complementos a redução do indivíduo à sua história privada e o culto à novidade, como verificado a partir das informações jornalísticas. ${ }^{3}$

O tipo de experiência então retransmitida pela narração, por não possuir um sentido evidente nem uma explicação total dos fatos por uma versão única destes, possibilitava interpretações futuras que

2 Cabe ressaltar certa ambiguidade no pensamento de Walter Benjamin. Em seu artigo A obra de arte na era de sua reprodutibilidade técnica (1994), o autor acentua o caráter progressista do cinema que, além de abalar a tradição, mudaria a relação da arte com a massa, possibilitando uma atitude crítica por parte desta. Ou seja, haveria possibilidades de alteração das relações sociais mesmo com a queda da experiência. Contudo, esse texto de Benjamin dialoga com a indústria nazista de cinema, e clama pela necessidade de expropriação do capital aos recursos cinematográficos. De qualquer modo, a preocupação não deixa de estar vinculada às transformações da sociedade capitalista e de seu violento avanço. Agradeço à Maria Carolina Trovo pela leitura da versão preliminar desse texto e pela sugestão desta ressalva.

3 Para Walter Benjamin (2004), os jornais são indícios da redução das chances que o indivíduo tem para se apossar de sua própria experiência. De acordo com o autor, o propósito da imprensa é o de "isolar os acontecimentos do âmbito onde pudessem afetar a experiência do leitor", privando-o de imaginação (p.106). E completa que a narração "não tem a pretensão de transmitir um acontecimento pura e simplesmente (como a informação o faz); integra-o à vida do narrador, para passá-lo aos ouvintes como experiência" (p.107). 


\section{DANIELLE TEGA}

reafirmavam o caráter inacabado do passado. Nesse sentido, Walter Benjamin retoma novamente as leituras de Marcel Proust, concordando com este em destacar que o passado comporta elementos inacabados à espera de vida posterior, elementos que podem ser revividos através das ressurreições da memória. No entanto, faz uma ressalva: nas obras de Proust, esses ressurgimentos da memória dependem do acaso e se referem ao passado individual; já para Benjamin (1996, p.37), a lembrança proustiana escapa da limitação da memória individual ao abrir a dimensão do infinito, pois "um acontecimento vivido é finito, ou pelo menos encerrado na esfera do vivido, ao passo que o acontecimento lembrado é sem limites, porque é apenas uma chave para tudo o que veio antes e depois".

O pensador alemão acredita, portanto, que essas ressurreições da memória não podem depender do acaso: referem-se a um passado coletivo que necessita de uma reconstrução voluntária de suas condições de possibilidade. Em suas teses Sobre o conceito da história, ${ }^{4}$ o autor aponta a importância de realizar tal tarefa, como explica Jeanne Marie Gagnebin (1982, p.60):

[...] a verdade do passado reside antes no leque dos possíveis que ele encerra, tenham eles se realizado ou não. A tarefa da crítica materialista será justamente revelar esses possíveis esquecidos, mostrar que o passado comportava outros futuros além deste que realmente ocorreu. Trata-se, para Benjamin, de resgatar do esquecimento aquilo que teria podido fazer de nossa história uma outra história. A empresa crítica converge, assim, para a questão da memória e do esquecimento, na luta para tirar do silêncio um passado que a história oficial não conta.

O processo de transmissão cultural, que é parte comprometida na história da dominação burguesa, possui marcas deixadas pelos interesses das classes dominantes, marcas estas que devem ser de-

4 Utilizo a tradução feita por Sérgio Paulo Rouanet publicada no livro Magia e técnica, arte e política (1994, p.222-232). Nas citações, optei por indicar os números das teses no lugar de indicar os números das páginas. 
nunciadas com um sentido claro: para Benjamin, o resgate do passado no presente permite uma reflexão com perspectiva futura; em suas palavras, "a luta da classe trabalhadora se nutre da imagem dos antepassados escravizados, e não dos netos libertos" (tese 12). A reflexão sobre o passado é uma passagem necessária, pois não há futuro emancipado sem esse resgate. Mas de que passado fala o filósofo? E que resgate seria este que sinaliza? De acordo com o autor, trata-se do passado pendente, truncado, interrompido; aquele que não pode realizar-se em seu próprio presente. Invocá-lo não é apenas fazer um resgate histórico, mas requer um rememorar no pensar dialético: à atividade reflexiva deve ser somada a prática revolucionária no presente, rompendo o "continuum da história", o "tempo homogêneo e vazio" (tese 14).

Ainda em suas teses (escritas pouco antes de seu suicídio em setembro de 1940 e contendo, portanto, as marcas dos violentos conflitos do período no qual se inserem), ${ }^{5}$ o pensador alemão reclama uma crítica materialista cuja visão histórica seja a da luta permanente entre oprimidos e opressores, e que seja uma oponente drástica tanto da filosofia burguesa como do materialismo determinista. ${ }^{6}$

5 Como informa Jeanne Marie Gagnebin (2009, p.27), “a redação das ‘teses' se dá provavelmente entre setembro de 1939 (início da Segunda Guerra) e abril de 1940 (construção do campo de concentração de Auschwitz), isto é, em um dos momentos mais negros da história europeia. Portanto, não é um texto escrito na serenidade de um gabinete, mas em um quarto de exílio: ele pede aos leitores que não procurem por soluções ou respostas, mas que aceitem o fim de suas certezas sobre o curso da história e a formulações de questões novas, mesmo que continuem sem resposta".

6 Examinando tanto o exemplo do Partido Social-Democrata como o Partido Comunista de então, Walter Benjamin destaca que o conformismo condiciona as táticas políticas e as ideias econômicas de ambos. A crença no progresso, cuja concepção histórica se protege sob o materialismo vulgar que acabava difundindo um determinismo otimista, é duramente criticada por Benjamin: ao vincular o progresso da humanidade ao progresso da tecnologia como caminho da libertação social, essa crença desconsiderava a forma de uso e consequências da própria técnica. Atento aos acontecimentos do contexto alemão, o autor afirma que o "ponto de partida é a ideia de que a obtusa fé no progresso" leva a tais 
Walter Benjamin contrapõe-se, assim, a uma historiografia tradicional que acredita na capacidade de se restituir o passado "por inteiro", e reitera a necessidade de se escrever a história dos vencidos - o que exige a busca de uma memória não oficial, uma interpretação capaz de "escovar a história a contrapelo" (tese 7). Nessa perspectiva, torna-se imprescindível um materialismo histórico comprometido com a construção dos passados possíveis, com aquilo que não foi realizado porque a dominação se impôs. Nas palavras de Jeanne Marie Gagnebin (1982, p.73),

Certo, o passado está consumado e é irreparável. Mas podemos, segundo Benjamin, ser-lhe fiel para além de seu fim, retomando em consideração suas exigências deixadas sem resposta. Cada geração recebe assim uma 'tênue força messiânica' (tese II), porque cabe a cada presente resgatar o próprio passado; não apenas para guardá-lo e conservá-lo, mas também libertá-lo. [...] O trabalho do historiador materialista é arrebatar ao esquecimento a história dos vencidos e, a partir daí mesmo, empenhar-se numa dupla libertação: a dos vencidos de ontem e de hoje. [grifos da autora]

Esse trabalho de rememoração, que faz ressurgirem do passado histórias antes fadadas ao esquecimento, traz consigo a possibilidade de diversas interpretações desse passado. Nesse sentido, Jeanne Marie Gagnebin (2007, p.3) faz um alerta fundamental sobre o pensamento de Benjamin: o fluxo constitutivo da memória é atravessado, mesmo que de forma subterrânea, pelo refluxo do esquecimento, que, longe de ser considerado apenas como uma falha da memória, é também uma atividade que recorta e seleciona, a qual "opõe o infinito da memória a finitude necessária da morte e a inscreve no âmago da narração". A memória é tecida com as tramas da rememoração e do esquecimento, tal qual o trabalho de Penélope retratado pelo pensador alemão no texto A imagem de Proust (Benjamin, 1996): tra-

concepções da história: o fato de acreditar que nadava com a corrente (do desenvolvimento técnico) foi corruptor para a classe operária alemã. (Benjamin, 1996, p.227). 
ta-se de um esquecer como princípio produtivo, e não o esquecer manipulado. ${ }^{7}$ Esse paradoxo, além de ser característico da modernidade, nasce a partir de uma exigência contraditória da própria memória: por um lado, necessita "de reunião, de recolhimento, de salvação" e, por outro, "de esquecimento, de dispersão, de despedaçamento, de destruição alegre" (Gagnebin, 2007, p.6).

Impossível traçar essas observações sem fazer alusão ao pensamento que Theodor Adorno (2006) expõe em suas palestras $O$ que significa elaborar o passado e Educação após Auschwitz, realizadas respectivamente em 1959 e 1965. Nelas estão presentes marcas das reflexões de Benjamin, mas, diferente deste, Adorno pôde escrever a certa distância dos eventos catastróficos que se abateram na Europa e em parte do mundo em guerra.

De acordo com o autor, a destruição do indivíduo é um dos mecanismos que tornam os homens capazes de perpetrar um genocídio, e se encontra presente não apenas nos regimes totalitários, mas na sociedade de consumo movida pela troca. A existência de uma massa amorfa, sem presença de indivíduos autônomos, autocríticos e com vínculos sociais, possibilita a ocorrência de barbárie em tamanha amplitude. Concomitante a isso, percebe-se que a "mentalidade obstinada dos que nada querem ouvir a respeito desse assunto [do passado] encontra-se em conformidade com uma vigorosa tendência histórica” (p.32). Como consequência, longe de se elaborar o passado a partir dos fios da rememoração e do esquecimento produtivo, o

7 Como escreve Benjamin (1994, p.37), "Pois o importante, para o autor que rememora, não é o que ele viveu, mas o tecido de sua rememoração, o trabalho de Penélope da reminiscência. Ou seria preferível falar do trabalho de Penélope do esquecimento? A memória involuntária, de Proust, não está mais próxima do esquecimento que daquilo que em geral chamamos reminiscência? Não seria esse trabalho de rememoração espontânea, em que a recordação é a trama e o esquecimento a urdidura, o oposto do trabalho de Penélope, mais que sua cópia? Pois aqui é o dia que desfaz o trabalho da noite. Cada manhã, ao acordarmos, em geral fracos e apenas semiconscientes, seguramos em nossas mãos apenas algumas franjas da tapeçaria da existência vivida, tal como o esquecimento a teceu para nós". 
que se percebe é a destruição da memória, pois, em diversos âmbitos, a atividade de elaborar o passado é erroneamente formulada com a pretensão de "encerrar a questão do passado, se possível inclusive riscando-o da memória" (p.29). Esse desejo de se libertar do passado sem compreendê-lo é também notado nas lembranças da deportação e do genocídio, geralmente associadas a expressões moderadas ou ao uso de eufemismos, desencadeando em discursos vazios. Tal disposição em negar ou minimizar o ocorrido, ou melhor, tal inclinação a uma "destruição da memória", coincide com a estranheza da consciência numa sociedade cujos princípios (burgueses) estão subordinados à lei da troca. Equivalem-se, portanto, coisificação (ou reificação) e esquecimento, frutos de uma sociedade na qual os indivíduos já não mais fazem experiência - apenas trocas. Nas palavras de Adorno (2000, p.43),

A sobrevivência do fascismo e o insucesso da tão falada elaboração do passado, hoje desvirtuada em sua caricatura como esquecimento vazio e frio, devem-se à persistência dos pressupostos sociais objetivos que geram o fascismo. Este não pode ser produzido meramente a partir de disposições subjetivas. A ordem econômica e, seguindo seu modelo, em grande parte também a organização econômica, continuam obrigando a maioria das pessoas a depender de situações dadas em relação às quais são impotentes, bem como a se manter numa situação de não emancipação. Se as pessoas querem viver, nada lhes resta senão se adaptar à situação existente, se conformar; precisam abrir mão daquela subjetividade autônoma a que remete a ideia de democracia; conseguem sobreviver na medida em que abdicam seu próprio eu.

Seguindo esse caminho, o autor afirma que "apagar a memória seria muito mais um resultado da consciência vigilante do que resultado da fraqueza da consciência frente à superioridade de processos inconscientes" (idem, p.34). E é contra essa consciência coisificada que Adorno aponta a importância de se conferir um sentido à história a partir da reelaboração do passado ao presente e, nessa esteira, conceber o presente como apto à transformação, pois histórico. Nessa conjuntura de trauma e barbárie, Adorno faz, tal como Benjamin, 
uma defesa da visão histórica como fidelidade aos vencidos e a seus projetos não cumpridos. Como resume Márcio Seligmann-Silva (2003a, p.75) sobre esse ponto,

A crítica, assim como a psicanálise, visa a quebrar o quisto (ou a cripta) em que o trauma se enclausura - sem, no entanto, levar ao esquecimento do passado, mas libertando suas forças embotadas. Salvar o passado de opressão, ser fiel às utopias não realizadas, recordar os mortos, eis três dos motes centrais da filosofia após Auschwitz, aos quais a obra de Adorno nos conduz.

Trata-se de uma postura reprovadora da tendência à memória debilitada, postura esta que é acompanhada pelo sentido de justiça. Como acrescenta o autor, aquele que "ainda insiste em afirmar que o acontecido nem foi tão grave assim já está defendendo o que ocorreu”, e não há dúvidas de que "seria capaz de assistir ou colaborar se tudo acontecesse de novo” (Adorno, p.136). Talvez seja desnecessário discorrer outras palavras para entender a posição da Folha de S. Paulo ao utilizar o termo ditabranda! ${ }^{8}$

\section{Os trabalhos da memória: trauma e transformação libertadora}

O resgate do passado com finalidade libertadora, como já afirmava Walter Benjamin em seus diversos textos, implica muito mais

8 Cabe, contudo, destacar uma importante referência teórica sobre essa questão. Em sua tese de doutorado Cães de guarda: jornalistas e censores, do AI-5 à Constituição de 1988, defendida em 2001 na Unicamp e publicada em 2004 com o mesmo título pela Boitempo Editorial, Beatriz Kushnir mostra a estreita relação entre órgãos da imprensa e a repressão política. Um dos destaques de sua pesquisa é a trajetória da Folha da Tarde, hoje Folha de S. Paulo, que era reduto de um grupo de jornalistas colaboracionistas, muitos dos quais tinham cargos na Secretaria de Segurança Pública de São Paulo. Além disso, relata as ligações entre a Folha da Tarde e a Operação Bandeirantes (Oban), formação paramilitar que recebia apoiologístico e financeiro de grupos empresariais para atuar no extermínio dos oponentes políticos. 
que sua simples citação: para cumprir seu efeito de elaboração, é necessário que o passado seja retomado de maneira reflexiva. Esse exercício de reflexão pode abranger aquilo que diversos autores chamam de "trabalhos da memória".

Em livro que estuda a presença e os sentidos do passado nas ditaduras militares dos países do Cone Sul, Elizabeth Jelin (2002) optou pelo uso do conceito "trabalho" por ser este um traço distintivo da condição humana, colocando sujeitos e sociedade num lugar ativo e produtivo enquanto agentes de transformação num processo que modifica a si mesmo e ao mundo: "referir-se entonces a que la memória implica trabajo es incorporarla al quehacer que genera y transforma el mundo social" [grifo da autora].

O trabalho-ou exercício - da memória tem como atividade apresentar os enfoques e pensamentos sobre a história capazes de ser incorporados às elaborações e práticas orientadas a recriar perspectivas emancipatórias: a memória redescobre e recupera um passado em comum, o qual fornece elementos para se interpretar o presente, modificando-o ou preservando-o, mas sempre projetando o futuro. Nesse caminho, lembrar e esquecer são ambos importantes. Porém, quando esse esquecimento está pautado no recalque, o que de fato ocorre é a repetição - e não o esquecer no sentido produtivo. Trata-se de um ponto comum nas situações traumáticas, tanto no âmbito individual como no coletivo. Por esse motivo, trabalhar a memória é uma necessidade para a superação desses traumas individuais e coletivos. De acordo com a psicanalista Maria Rita Kehl(2004, p.228),

Trabalho implica transformação de uma coisa em outra; trabalhar a memória é transformar seus resíduos, de modo a que eles se incorporem aos termos da vida presente sem que precisem ser recalcados. É o trabalho da memória que permite o verdadeiro esquecimento, o desligamento das cargas libidinosas fixadas às representações da cena traumática.

Mas como realizar um esquecimento verdadeiro se o luto ainda não foi possível? Esse ponto reacende a figura do "desaparecido político", dos militantes mortos cujos corpos continuam escondidos, 
sepultados sem lápides em terrenos cujas covas trazem consigo as marcas da brutalidade. ${ }^{9}$ Tal prática, ocorrida no Brasil e em outros países do Cone Sul, torna o exercício da memória ainda mais difícil: como realizá-lo antes, quando mães e pais ainda aguardavam a volta de seus filhos e filhas para a casa? E como realizá-lo agora, quando companheiros e companheiras ainda são aguardados por seus cônjuges, filhos e filhas? Em suma, qual a possibilidade de realizar o trabalho da memória quando a sociedade não vela seus corpos, nos quais estão cravadas as marcas da luta de uma geração?

Tratando-se de um período traumático, mais obstáculos são visíveis. Um deles é que o trabalho de memória não depende apenas daqueles que viveram o horror; ele necessita, tal qual a narração, da contrapartida da escuta, ou seja, necessita de testemunhas num sentido mais amplo do termo. Como explica Jeanne Marie Gagnebin (2006, p.93), "testemunha também seria aquele que não vai embora, que consegue ouvir a narração insuportável do outro e aceita que suas palavras revezem a história do outro". Porém, como já alertou Adorno em referência às relações entre catástrofe e capitalismo, há uma inclinação histórica marcada pela carência de ouvintes.

Para Daniel Aarão Reis (2005), após a Lei da Anistia houve um espaço para a sociedade brasileira poder exercitar a memória sobre o então passado recente. Nas reconstruções históricas realizadas naquele momento, ocorreram certos deslocamentos de sentido que se fixaram na memória nacional como verdades irrefutáveis. Segundo o historiador, o primeiro deslocamento foi promovido por quem apoiava a Anistia, que apontavam todos os grupos de esquerda como democráticos, apagando-se as perspectivas ofensivas e revolucionárias de grande parte destes, muitos dos quais desprezavam a democracia em seus textos. Num outro deslocamento apontado, a sociedade bra-

9 Sobre esse assunto, há um interessante documentário, dirigido em 1994 por João Godoy, chamado Vala Comum. O filme trata da abertura da vala clandestina no Cemitério de Perus em 1990, época em que Luiza Erundina era prefeita da cidade de São Paulo (1989-1993). Tanto a abertura da vala como o filme são marcos importantes na reconstrução da memória da ditadura. 
sileira foi reconfigurada como se tivesse se oposto à ditadura desde seu início - e de forma maciça e contundente. Nessa reconstrução, apagou-se o amplo movimento de massas organizado nas Marchas da Família com Deus e pela Liberdade, cuja formação serviu como fator de legitimação social para a instauração da ditadura. Desapareceram também os laços tecidos "entre a sociedade e a ditadura ao longo dos anos 1970, e que, no limite, constituíram os fundamentos do próprio processo da abertura lenta, segura e gradual” (p.71).

Esses deslocamentos evidenciam também a dificuldade que o próprio sujeito ou sociedade tem para lidar com a situação, pois esta imprime feridas na memória que causam o impedimento de abstração perante o evento. Verifica-se, portanto, um paradoxo: os fatos traumáticos necessitam de compreensão e narração, mas possuem em seu cerne os impedimentos de sua elaboração.

Contudo, a própria impossibilidade de dar sentido a um acontecimento passado e incorporá-lo narrativamente é o que indica a presença do trauma. Nessa situação, o esquecimento não é ausência ou vazio, mas sim a presença dessa ausência. Sob esse prisma, fica mais claro o significado das alternativas que Adorno (op. cit., p.46) oferece ao tratar a maneira pela qual o passado será referido no presente, se "permanecemos no simples remorso ou se resistimos ao horror com base na força de compreender até mesmo o incompreensível". Recalcar o passado ou perceber que o incompreensível e o inenarrável são os próprios sinais do trauma e, portanto, vestígios desse passado traumático? Desnecessário enfatizar que o esforço de Adorno concentra-se na segunda opção.

$\mathrm{O}$ ato de rememorar, dado o caráter seletivo da memória - que, como já se observou, é acompanhada pelo esquecimento -, oferece possibilidades de diferentes representações desse passado. De acordo com Elizabeth Jelin (op. cit., p.14), "hay nessa situación um doble peligro: el de um exceso de pasado em la repetición ritualizada, en la compulsión que lleva al acto, y el de um olvido selectivo, instrumentalizado y manipulado”. É contra essa situação que se requer trabalhar, elaborar, incorporar memórias e recordações. Mesmo aquelas individuais e privadas são constitutivamente de caráter so- 
cial, posto que suas mediações estão culturalmente implicadas. Desse modo, deve-se dar atenção ao "peso relativo del contexto social y de lo individual em los procesos de memoria. [...] Las memorias individuales están siempre enmarcadas socialmente" (idem, p.20). Pelo exercício da memória, facilita-se a inserção dessas rememorações na esfera pública, convertendo as lições do passado em princípios para o presente no intuito de projetar-se o futuro.

\section{Memórias em luta: conflitos na procura pela "verdade"}

A possibilidade de diferentes representações do passado dada a partir da rememoração sugere a existência de memórias em luta nas sociedades, memórias estas cujas recordações são atos compartilhados e objetos de controvérsias. As memórias não estão apartadas das relações e dos conflitos sociais; ao contrário, aquilo que se recorda e o modo pelo qual se recorda são dimensões fundamentais dos processos sociopolíticos.

Uma das medidas do golpe civil-militar foi destruir a imagem de seus opositores, apresentando-os como terroristas, vermelhos, agentes de Moscou etc. Eram também satirizados quando apresentados como drogados e porra-loucas. E havia também a versão de jovens e inocentes cooptados por velhos comunistas radicais. Essas imagens foram divulgadas e tornadas públicas por setores complacentes ao regime em questão, como a imprensa escrita e televisiva, e reutilizadas pelos aparatos repressivos do Estado, como as delegacias e os tribunais. As reparações dessas e de outras medidas se inserem na luta política pelo passado e, nesse sentido, estudos já realizados sobre o período oferecem importantes instrumentos de análise. A partir deles, podem-se compreender as condições que levaram a militância a diferentes tipos de ações contra a ditadura, bem como verificar que tanto as escolhas como os perfis dos/das militantes são bem mais complexos que os estereótipos divulgados pela versão daqueles que estavam no poder. Vejamos resumidamente o caso da luta armada. 
Como afirma Marcelo Ridenti (1997), as organizações guerrilheiras apresentam diferenças significativas em diversos pontos. Sobre o caráter da revolução brasileira, dividiam-se entre os que pretendiam uma revolução nacional e democrática numa primeira etapa, e aqueles que a pensavam como imediatamente socialista. Em relação às formas de luta para chegar ao poder, tinham grupos de inspiração guevarista, outros de inspiração maoísta, e ainda os que defendiam a insurreição popular. Também o tipo de organização política a ser construída não era um ponto em comum, pois havia muito debate sobre a necessidade ou não de um partido nos moldes leninistas.

Apesar das diferenças, as organizações guerrilheiras tinham como ponto convergente a prioridade revolucionária da ação armada, contrariando os pressupostos de certos grupos e partidos, como o PCB. Acreditavam que as condições objetivas para a revolução (seja ela nacional e democrática num primeiro momento, seja ela com caráter imediatamente socialista) estavam dadas, pois interpretavam que a economia brasileira estaria num processo de estagnação, com o desenvolvimento das forças produtivas bloqueado sob o capitalismo por meio da aliança entre os interesses da burguesia brasileira com os dos imperialistas e latifundiários. Nessas condições, somente o governo popular - ou socialista - poderia retomar o desenvolvimento.

Faltavam, contudo, as condições subjetivas - e caberia à vanguarda revolucionária urdi-las, com armas nas mãos para preparar as condições da guerrilha, que deveria ser deflagrada a partir do campo. Para angariar dinheiro e armamentos com tal finalidade, as organizações armadas realizavam ações urbanas, como expropriações de bancos e furtos de armas.

Tendo como política de Estado o assassinato e a tortura dos militantes contrários à ditadura militar, o aparato repressivo desmantelou rapidamente esses grupos, principalmente no período de 1969 a 1971, impedindo-os de irromper a guerrilha rural. Apenas a do PCdoB foi lançada na região do Araguaia, mas poucos guerrilheiros sobreviveram entre 1972 e 1974, período de intensa luta entre soldados e revolucionários. 
Faço aqui uma ressalva para evitar cair em uma armadilha teórica. Se não há uma versão definitiva dos fatos, se não existe uma história objetiva e única dos acontecimentos que pode ser descoberta por historiadores ou demais pesquisadores, então é possível afirmar que todas as versões são... relativas? Não. Lutar contra o esquecimento e a denegação, ou seja, lutar contra a mentira, não significa inclinar-se numa definição dogmática da verdade, tampouco significa curvar-se a um relativismo complacente. Como diz Jeanne Marie Gagnebin (1998, p.213), a verdade do passado que se busca "não é de ordem da adequação, mas remete a uma vontade de verdade, que é ao mesmo tempo ética e política". Nesse sentido, o passado é articulado - e não descrito. $\mathrm{O}$ que está em pauta é a historicidade do discurso, a relação específica que o presente do historiador mantém com determinado momento do passado. O esquecimento da censura, da tortura e das mortes permite a reinserção das práticas repressivas em outros seres humanos. Portanto, a procura pela verdade é, nas palavras da autora (idem, p.221):

Tarefa altamente política: lutar contra o esquecimento e a denegação é também lutar contra a repetição do horror (que, infelizmente, se reproduz constantemente). Tarefa igualmente ética e, num sentido amplo, especificamente psíquica: as palavras do historiador ajudam a enterrar os mortos do passado e a cavar um túmulo para aqueles que dele foram privados. Trabalho com o luto que deve ajudar, nós, os vivos, a nos lembrarmos dos mortos para melhor viver hoje. Assim, a preocupação com a verdade do passado se completa na exigência de um presente que, também, possa ser verdadeiro.

Com isso fica mais fácil entender os espaços para as contramemórias, para as narrações do passado que se opuseram às versões oficiais. Explicações que insistem numa tentativa de interpretação objetiva ou neutra dos fatos ocorridos já são proposições coerentes com o processo hegemônico, o que indica que a seleção do que se recorda e do que não se recorda está num campo marcado pelas relações de poder e controlado por esferas das classes dominantes. Ao tratar do assunto, Elizabeth Jelin (2002, p.6) faz o seguinte comentário: 
Siempre habrá otras historias, otras memorias e interpretaciones alternativas, en la resistencia, in el mundo privado, en las catacumbas. Hay una lucha politica activa acerca del sentido de lo ocorrido, pero también acerca del sentido de la memoria misma. El espacio de la memoria es entonces un espacio de lucha política.

A autora destaca que, muitas vezes, tal luta política é compreendida em termos de "memória contra o esquecimento" ou "memória contra o silêncio"; no entanto, esse tipo de entendimento esconde o que, de fato, é uma oposição entre diferentes memórias rivais - ou "memória contra memória" -, cada qual com seus próprios esquecimentos. Os conflitos não estão limitados às memórias que se rivalizam entre si, nem são sempre homogêneos e coerentes. Na verdade, diversos grupos apresentam memórias muitas vezes divididas e fragmentadas, manifestando divisões e discordâncias internas que podem ter ficado latentes nos períodos anteriores. As coesões desses diferentes grupos (políticos, sociais e culturais) podem ser reforçadas ou debilitadas por meio da função política exercida pelas representações do passado nas manifestações coletivas.

Nessa perspectiva, é fundamental a exposição dos conflitos que habitam os eventos passados e, para isso, torna-se necessário esclarecer as diferentes interpretações sobre eles - mesmo que, novamente, as diferentes memórias coloquem-se em conflito. As memórias se constroem, portanto, em cenários de confronto e lutas entre os sujeitos e suas diversas narrativas contrastantes. Como acrescentam Alejandra Oberti e Roberto Pittaluga (2006, p.30),

En el campo conflictual de las memorias, éstas son expressión de enfrentamientos sociales, políticos y/o culturales, pero en el mismo movimiento establecen ciertas determinaciones, ejercen presiones y fijan límites; tanto por médio de la selección de lo que se recuerda y lo que no se recuerda como por los modos con los que el pasado es presentado. Podríamos decir que los trabajos de memoria están determinados por sus propios contextos de producción y a la vez influyen modificando, al menos parcialmente, esos mismos contextos. 
Essa observação indica que as modificações nos marcos interpretativos produzidas pelo processo histórico devem ser consideradas, pois novos cenários sociais e políticos interferem não apenas na percepção do passado, mas também nas alterações das formas de luta. Amparo-me, novamente, nas palavras que Jeanne Marie Gagnebin (1982, p.58-59) profere a respeito do pensamento de Walter Benjamin:

O historiador materialista deve sempre se lembrar de que a imagem do passado - que é a sua imagem do passado - não pode oferecer um ponto de partida imediato à sua análise, mas que a condição prévia de todo julgamento do passado é o exame crítico da constituição histórica da representação desse passado.

Por esse caminho, verifica-se a importância de se compreender o modo pelo qual o passado é mencionado no presente por meio do trabalho da memória, o que possibilita a observação dos conflitos desta em diferentes contextos, bem como seu potencial libertador. A próxima etapa é expor os entrecruzamentos entre o estudo da memória e o pensamento feminista, mostrando a importância de ambos para uma compreensão possível dos filmes escolhidos neste estudo.

\section{Feminismo em tempos de rebeldia}

Walter Benjamin já denunciara a historiografia classista dos vencedores e a necessidade de superá-la ao propor uma compreensão da história "a contrapelo", que recuperasse a história dos vencidos. A crítica feminista, também preocupada com as partes silenciadas da memória social, amplia essa denúncia ao expor o caráter sexista da historiografia burguesa. Ao mesmo tempo em que expõe a invisibilidade da mulher na história oficial, o pensamento feminista questiona o modo pelo qual a desigualdade entre homens e mulheres se estabeleceu e quais as formas de se eliminar essa assimetria. 
Para que não se entenda o feminismo como um pensamento apartado dos processos sócio-históricos, exponho brevemente as condições materiais nas quais ele surgiu enquanto movimento social, fazendo referência às suas principais tendências. O que interessa para o debate proposto neste livro é a compreensão do movimento que emerge nas décadas de 60 e 70, frutos de efervescências políticas e culturais ocorridas em várias partes do mundo.

Um retorno ao período da Segunda Guerra permite verificar que diversas mudanças sociais ocorridas em tal contexto serviram como pano de fundo para o surgimento de um novo tipo de feminismo: a participação feminina era acolhida na esfera do trabalho em números maiores que em anos anteriores, principalmente em países diretamente envolvidos no conflito, como Estados Unidos e Inglaterra, já que as necessidades econômicas do momento histórico liberavam a mão de obra masculina para as frentes de batalha. Contudo, como afirmam Branca Moreira Alves e Jacqueline Pitanguy (2007), o retorno da força de trabalho masculina no final da guerra reativou uma ideologia que valorizava a diferenciação de papéis por sexo, atribuindo-se ao espaço doméstico a condição feminina, cujo intuito era o de ceder seus lugares no mercado de trabalho aos homens. As autoras acrescentam que "as mensagens veiculadas pelos meios de comunicação enfatizavam a imagem da rainh a do lar, exacerbando-se a mistificação do papel de dona-de-casa, esposa e mãe” (p.50).

Além desse "mal estar sem nome" 10 que tal situação ajudava a causar, o capitalismo americano do pós-guerra, com sua promessa de prosperidade econômica, consumo de bens duráveis e reforço nos valores da família, popularizado no american way of life, teve sua fragilidade exposta com a Guerra da Coreia e a Guerra do Vietnã, e também com o acirramento dos conflitos raciais. No mesmo período, o continente europeu tinha outras questões em debate, como a desilusão com a proposta socialista a partir da revelação dos crimes

10 Expressão usada por Betty Friedan em A mística feminina, considerada a primeira obra feminista dos anos 1960 nos EUA. 
stalinistas e as invasões da Hungria e da Tchecoslováquia. Tanto o capitalismo quanto o socialismo eram minados, universidades foram ocupadas, barricadas realizadas. Como explica Céli Regina Jardim Pinto (2003, p.42),

O movimento jovem da década de 60 não foi apenas altamente inovador em termos políticos; foi, talvez antes de tudo, um movimento revolucionário na medida em que colocou em xeque os valores conservadores da organização social: eram as relações de poder e hierarquia nos âmbitos público e privado que estavam sendo desafiadas.

Foi nesse cenário de revolução de costumes e de radical renovação cultural que eclodiu o movimento feminista nos Estados Unidos e depois na Europa, e muitos temas por ele questionados eram próximos aos dos movimentos negro e estudantil. A participação no mercado de trabalho, a elevação do nível de escolaridade e os progressos da medicina em relação ao controle das funções reprodutivas ampliaram os horizontes e as percepções das mulheres sobre os limites da estrutura vigente. Maria Lygia Quartim de Moraes (2002, p.17) afirma que:

A rapidez das transformações econômicas e o impacto que tiveram sobre o antigo modelo familiar, baseado na complementaridade de papéis, com o pai provedor exclusivo e a mãe dedicando-se aos trabalhos domésticos e às crianças, levaram à redefinição dos papéis familiares, com um número de mulheres cada vez maior ingressando no mercado de trabalho. E, como não poderia deixar de ser, o alargamento das experiências femininas para além dos limites domésticos possibilitou o aparecimento de um ativo movimento de mulheres e, no seio, um feminismo politicamente ativo.

Ao questionar de forma contundente a sociedade, dando destaque para a maneira pela qual os "papéis sexuais" são estabelecidos, divergências internas aparecem dentro do próprio movimento, tanto nas questões sobre as origens da desigualdade entre homens e mulheres, como nas que se referem sobre as formas de luta para eli- 
minar tal disparidade. Como sugere Anette Goldberg (1987), as principais tendências presentes no movimento feminista que surge a partir dos anos 1960, grosso modo, são: Feminismo Liberal, Feminismo Radical e Feminismo Marxista ou Socialista.

O Feminismo Liberal, também conhecido como Feminismo Igualitário ou Feminismo Universalista, verifica a origem da desigualdade entre homens e mulheres nos resquícios de condições socioculturais anacrônicas. Como as feministas dessa corrente aderem ao pensamento liberal, pautam-se na conquista dos direitos civis como questão central da luta para eliminar todas as desigualdades: é um movimento que reivindica igualdade de direito e de fato para todas as mulheres em nome do direito inalienável de cada indivíduo à igualdade e à determinação. Nesse sentido, uma reforma no sistema capitalista já seria suficiente para atingir seus objetivos, bastando modificar a socialização e a educação das meninas, reformular as tarefas domésticas na família e favorecer acesso das mulheres aos locais do saber e de poder econômico ou político. Como resume Francine Descarries (2000),

A fim de que as mulheres e homens pudessem realizar seu potencial como indivíduos livres e autônomos. Ideologicamente fundada sobre uma perspectiva otimista quanto a capacidade de reforma do sistema patriarcal, a corrente igualitarista contava com a vontade e o investimento pessoal das mulheres para obter uma igualdade de chances com os homens. Constitui, de certa forma, a plataforma moderada do movimento das mulheres.

Já o Feminismo Radical vê a origem da desigualdade entre homens e mulheres no "patriarcado", que, segundo Kate Millet (1974), seria a política sexual por meio da qual os homens estabelecem seu poder, reprimindo as mulheres e mantendo-as sob seu controle. Diferente do feminismo igualitário, não critica os "papéis sexuais", mas as estruturas nas quais sobrevive um determinismo biológico que subjuga as mulheres. Nesse sentido, se opõe a qualquer tipo de compromisso nos moldes liberais, pois a injustiça contra as mulheres não 
é vista como consequência de qualquer tipo de anacronismo, mas fruto de uma ordem patriarcal sexista e da manifestação de poder alimentada pelos conflitos entre "classes de sexos".

As feministas radicais rompem com a tradição socialista, já que esta recusa a especificidade da questão feminina ao negar a necessidade de práxis e instrumentos próprios para a superação da desigualdade entre homens e mulheres. $\mathrm{O}$ feminismo radical rejeita, portanto, que a contradição principal da sociedade seja a luta entre as classes socioeconômicas: o inimigo principal a ser combatido é o poder dos homens, e as extinções da hierarquia sexual e do modo de organização que gera esse tipo de relações sociais só ocorrerão no momento em que todas as mulheres forem liberadas de suas funções biológicas ou dos deveres de maternage (maternidade e cuidados).

Com a finalidade de destruir o patriarcado expresso nos termos acima, esse feminismo propõe a sublevação das mulheres, uma "revolução feminista". Para alcançar tal objetivo, formam pequenos grupos de autoconsciência com discussões de experiências pessoais e cotidianas, procurando converter a consciência da opressão comum em consciência política capaz de uma transformação radical da sociedade.

O Feminismo Marxista também submete a tradição socialista a uma crítica radical ao observar que o marxismo não oferece solução teórica à opressão feminina. Muitas feministas dessa tendência apontam a persistência da hierarquia entre homens e mulheres nos países considerados socialistas como comprovação de que a abolição da propriedade privada não é suficiente para a liberação das mulheres. Para que esta condição se realize, dimensões diversas que não são alteradas por meio de transformações institucionais e/ou jurídicas estão em pauta. Nesse sentido, como resume Maira Luisa Gonçalves de Abreu (2006), a revolução é considerada "um processo complexo e multilateral que abrange desde a sexualidade e as relações do microcosmo familiar até as relações da interconexão da totalidade viva da sociedade."

Diferentemente das radicais, as reformulações teóricas que as feministas socialistas defendem não abandonam o marxismo, mas pro- 
põem um marco conceitual a partir do qual fosse possível analisar a questão da opressão das mulheres. Uma perspectiva dessa nova elaboração teórica foi considerar duas formas de opressão - a subordinação estrutural do trabalho ao capital que envolvia a classe trabalhadora; e uma segunda forma que atingiria especificamente a mulher. Com isso, ampliam a teoria marxista a fim de incorporá-la como parte da práxis revolucionária feminista: a luta contra a exploração capitalista, que é travada entre as classes sociais, deve ser travada simultaneamente à luta contra a opressão feminina. Eis o ponto crucial das diferenças entre o feminismo liberal e o feminismo socialista: para as liberais, a igualdade entre os sexos não precisa estar relacionada à questão das hierarquias de classe; para as socialistas, a emancipação das mulheres "exige a superação do patriarcalismo e do capitalismo” (Moraes, 2003, p.121).

Partindo das considerações acima expostas, pode-se imaginar que dentro dessas tendências outras correntes surgiram, e que o feminismo passou a incorporar uma série de discursos diversificados, resultando numa variedade de feminismos. Porém, a heterogeneidade interna não enfraqueceu a importância política do movimento ou do pensamento feminista: assinaladas suas distinções teóricas e de visão de mundo, o que interessa expor são algumas rearticulações que tenham como objetivo uma sociedade não sexista, baseada na emergência de sujeitos-mulheres plenamente autônomos.

Principalmente a partir do livro $O$ segundo sexo, no qual Simone de Beauvoir indica que não se nasce mulher, mas se torna mulher, desvelou-se que a condição de subordinação das mulheres não se deve às questões naturais ou biológicas, mas sim às construções sociais e suas respectivas relações de poder. Observou-se, assim, que esses processos sociais são hierarquizados de tal forma a fazer uma distinção entre a esfera pública e a esfera privada, estabelecendo uma rígida separação de poder. A esfera privada, onde se localizam as mulheres, restringe-se ao lar e à família; a esfera pública, masculina, é onde se centraliza o poder. O silêncio sobre a história das mulheres decorreria de sua não participação na arena pública, considerada o espaço da política por excelência. Como afirma Lucila Scavone(2008, 
p.178), foram os debates sobre esses temas que deram "visibilidade às relações de dominação e poder que dividem o mundo social em gêneros e que questionaram uma ordem sexual tida como natural". Desnudando os conceitos e práticas patriarcais de divisão sexual do trabalho, observou-se que tal hierarquia era fruto da dominação cujas violências físicas e simbólicas contra as mulheres serviam como mecanismo de controle social. O exame das práticas sociais que condicionavam as mulheres fora do âmbito do conhecimento é estritamente ligado à procura pela transformação nas relações de gênero.

Convém enfatizar que o uso do termo gênero não está num discurso vazio, a-histórico, mas marcado por contextos diversos e permeado por estruturas sociopolíticas as quais, numa relação dialética, o gênero não apenas faz parte, como também as produz. Joan Scott (1990, p.13) explica que gênero é a categoria de análise para teorizar as práticas feministas, e acrescenta que

[...] gênero é um elemento constitutivo de relações sociais fundadas sobre as diferenças percebidas entre os sexos, e o gênero é um primeiro modo de dar significado às relações de poder. As mudanças na organização das relações sociais correspondem sempre a mudanças nas representações do poder, mas a direção da mudança não segue necessariamente um único sentido.

Para Teresa de Lauretis (1994), um sistema de gênero é formado dentro de cada cultura a partir de concepções culturais de masculino e feminino, concepções estas entendidas como duas categorias complementares, mas que se excluem mutuamente, e nas quais todos os seres humanos são classificados. As diferentes formas de socialização de homens e mulheres, ainda hoje fortemente presentes, são exemplos desse tipo de concepção: desde crianças, as meninas são educadas para serem doces, passivas, dependentes e obedientes em suma, inferiores aos homens. Já os meninos aprendem a ser competitivos, ativos, independentes e agressivos. Contudo, longe de ser uma estrutura estanque, esse sistema de significações relaciona o sexo a conteúdos culturais de acordo com valores e hierarquias sociais 
que, embora possam variar de uma cultura para outra, está sempre intimamente interligado a fatores políticos e econômicos em cada sociedade. A construção social do sexo em gênero e a assimetria que caracteriza tal sistema em diferentes culturas, embora cada qual a seu modo, estão sistematicamente ligadas à organização da desigualdade social.

$\mathrm{Na}$ crítica às práticas sociais que reafirmam certas convenções de feminilidade e masculinidade, o feminismo demonstra que a hierarquia sexual é um processo histórico, desconstruindo tal oposição binária. Sob esse aspecto, pode-se dizer que o feminismo atua como uma contramemória: nas margens dos discursos hegemônicos, existem termos para uma construção diferente das relações de gênero. De acordo com Margareth Rago (2003, p.15),

Suprimidas da História, [as mulheres] foram alocadas na figura da passividade, do silêncio, da sombra na esfera desvalorizada do privado. O feminismo aponta para a crítica da grande narrativa da História, mostrando as malhas de poder que sustentam [tais] redes discursivas. [...] É claro que se as mulheres foram um dos grandes setores excluídos da História, sabemos que não se trata apenas de recuperá-las em todos os grandes feitos, inscrevendo-as disciplinadamente nos espaços deixados em branco na Grande Narrativa Histórica, masculina e branca. As informações, os nomes e os fatos contidos nos documentos históricos são certamente fundamentais, sem eles, não se tem História. Contudo, também sabemos que não é suficiente refazer todo o percurso já jeito, desta vez no feminino.

Como pode ser observado nas palavras acima, o feminismo, ao denunciar a historiografia burguesa, protesta por outro tipo de história e, entendido numa perspectiva benjaminiana, enfatiza a importância de saber sobre qual passado se fala, qual passado deve ser lembrado e resgatado, demonstrando a necessidade de se pensar o presente com perspectiva futura, articulando a reconstituição desse passado a experiências políticas emancipatórias.

O pensamento feminista preocupa-se com as partes silenciadas da memória social, ausentes em livros escolares e em registros histó- 
ricos, e busca recuperar a presença das mulheres na história ao observar suas condições de luta. No livro Memórias das mulheres do exílio (Costa et. al., 1980, p.17), as organizadoras expõem essa inquietação:

As mulheres, como todos aqueles que nunca foram reconhecidos pela historiografia, não têm a sua história registrada. Disso decorre que o arrolar dos testemunhos do presente sobre o presente, das histórias de vida, da tradição oral, seja um esforço de reconstituição, assim como uma tentativa de dar livre curso à nossa imaginação e à nossa criatividade, de dar instrumentos para o domínio do futuro.

Portanto, uma maneira de pensar a dimensão de gênero na memória parte do enfoque tradicional no feminismo de fazer visível o invisível, dando voz àquelas que foram, por muito tempo, caladas. Mas o trabalho de memória feito pelas feministas, mais do que dar visibilidade às mulheres, procurou entender a situação destas como produto da história e da sociedade, denunciando as marcas autoritárias e hierárquicas do processo histórico das relações de gênero. Nesse sentido, compreende o presente como histórico e apto a práxis transformadora: como movimento emancipatório, o feminismo procura superar as formas de organização tradicionais em busca da libertação das mulheres.

Até esse ponto, utilizei o termo mulheres para enfatizá-las enquanto sujeitos políticos. Contudo, outros determinantes sociais definem suas vidas enquanto indivíduos: as classes sociais e as etnias inscrevem-se em cada mulher particular, gerando outras formas de opressão e conflitos de interesses, tendo como consequência política a fragmentação das mulheres. Como afirma Maria Lygia Quartim de Moraes (2003, p.33),

O fato das mulheres terem sua participação na vida social determinada por três elementos qualitativamente distintos - sexo, classe e etnia-raça - explicam em parte as fraquezas e os limites dos diversos movimentos femininos que a história conhece. Todas as mulheres sofrem a mesma discriminação sexual e têm, nesse sentido, reivindicações comuns. Mas a impossibilidade de transformar essas reivindicações numa 
plataforma única, de sensibilizar todas as mulheres em relação a essa plataforma, está dada pelas contradições situadas no âmbito da divisão de classes.

As violentas contradições do capitalismo são também base da memória debilitada, fruto de práticas sociais baseadas na troca e não na experiência, como já apontaram Benjamin e Adorno. Para este, a elaboração do passadoé essencialmente uma inflexão ao sujeito, um reforço de sua autoconsciência e, nesse caminho, um reforço do seu $e u$. Por essa via, o trabalho de memória feito pelo feminismo foi fundamental ao considerar a mulher enquanto sujeito, ao expor a condição específica de alienação na qual estava historicamente submetida, e ao buscar um resgate do passado comprometido a uma práxis transformadora. Contudo, retomando o pensamento de Adorno (op. cit.), o passado só estará plenamente elaborado no instante em que estiverem eliminadas as causas do que passou.

Não são poucas as situações que elucidam a permanência dessas causas na sociedade, dada a estabilidade das relações sociais reificadas, das hierarquias e do autoritarismo, bem como do racismo e machismo - pensando no caso brasileiro, que o digam homossexuais agredidos(as), pobres exterminados(as) por esquadrões da morte, mulheres agredidas pelos maridos, filhos e filhas agredidos(as) pelos pais e pelas mães. A atualidade do feminismo é, portanto, inquestionável: basta verificar essas frentes de luta nas quais ainda precisamos combater. Vejamos, assim, algumas considerações sobre o Feminismo no Brasil.

\section{Feminismo no Brasil em tempos de Ditadura}

Uma confluência de fatores contribui para a eclosão do feminismo brasileiro na década de 70. Para compreendê-los, é imprescindível um estudo do contexto em que se dão as participações femininas em tal momento histórico, resultado de acontecimentos e mudanças sociais anteriores. 
A plataforma nacional desenvolvimentista proposta pelo governo de Juscelino Kubitschek (1956-1961), cujo crescimento econômico era baseado na industrialização e na urbanização aceleradas, transformou diferentes aspectos do tecido social brasileiro. As expansões do sistema educacional e do mercado de trabalho ocorridos nos anos seguintes, mesmo em um país cuja modernização se dava de forma excludente, ofereciam novas oportunidades para as mulheres - principalmente nas camadas médias. Com isso, o modelo de socialização que tinha como base a realização pessoal a partir do casamento e da maternidade cedia lugar para um novo tipo de representações de feminilidade, especialmente nos grandes centros, que estimulava a profissionalização e o ingresso em cursos universitários.

Como bem observou Roberto Schwarz (2005), o panorama cultural brasileiro ao longo dos anos 1960 foi marcado por um paradoxo, pois havia relativa hegemonia da esquerda apesar da ditadura de direita a partir do golpe de 1964. Nesse contexto, o ambiente esquerdista em certas faculdades e nos meios artísticos foi um espaço de transgressão para um setor dessa juventude localizada, e algumas mulheres começaram a participar do movimento estudantil e de grupos políticos - organizações que, em pouco tempo, tornaram-se clandestinas. Embora não seja possível falar em feminismo nessa ocasião, estavam em pauta a contestação da virgindade, do casamento e da maternidade, discussões que eram "um instrumento em si de emancipação”, nas palavras de Marco Aurélio Garcia (1997). Para Lucila Scavone (2008), tratava-se de um novo acontecimento político, no qual as mulheres:

[rompem] com um dos mais consolidados mitos da dominação masculina de que política é negócio para homens. Subjacente a este acontecimento há os ecos da revolução das ideias e comportamentos dos países do norte que circulavam no meio da vanguarda política e cultural brasileira e os questionamentos dos tabus tradicionais relacionados à família e à sexualidade, que aprisionavam as mulheres no espaço doméstico. 
A partir de dados coletados no projeto Brasil: Nunca Mais, Marcelo Ridenti (1993) faz uma apresentação do perfil das organizações de esquerda dos anos 1960 e 1970, as quais eram compostas por ampla maioria masculina. Do total de processados, apenas 16\% eram mulheres. Desse número, $73 \%$ eram mulheres das camadas médias intelectualizadas, o que inclui estudantes, professoras e profissionais com formação superior. Considerando apenas as organizações armadas, verifica-se que $18 \%$ dos participantes processados eram mulheres e, dentre estas, $75 \%$ eram das camadas médias intelectualizadas - número que contrasta com o pouco envolvimento de mulheres em partidos políticos tradicionais, como o $\mathrm{PCB}$, onde menos de $5 \%$ do total de processados eram mulheres. Segundo Lucila Scavone (2008), esse dado sugere que as mulheres "se identificavam com uma proposta de ação política radical, tanto do ponto de vista da militância como de suas vidas pessoais".

Embora o percentual de mulheres pareça pequeno mesmo nos grupos armados, alguns elementos devem ser levados em conta para que não seja feita uma análise anacrônica. Seguindo as observações de Marcelo Ridenti (1997), deve-se lembrar que a norma, até os fins dos anos 1960, era a não participação das mulheres na política, exceto quando estas se manifestavam para reafirmar seus lugares de 'mães-esposas-donas-de-casa', como ocorreu com as mobilizações conservadoras femininas de apoio ao golpe na ocasião das Marchas da Família com Deus pela Liberdade. O autor acrescenta que:

A média de $18 \%$ de mulheres nos grupos armados reflete um progresso na liberação feminina no final da década de 60, quando muitas mulheres tomavam parte nas lutas políticas, para questionar a ordem estabelecida em todos os níveis, ainda que suas reivindicações não tivessem explicitamente um caráter feminista, que ganharia corpo só nos anos 70 e 80, em outras conjunturas. Não obstante, a participação feminina nas esquerdas armadas era um avanço para a ruptura do estereótipo da mulher restrita ao espaço privado e doméstico, enquanto mãe, esposa, irmã e dona de casa, que vive em função do mundo masculino. (Ridenti, 1997, p.198) 
Nesse sentido, como pondera Anette Goldberg (1987), a participação das mulheres nas organizações de esquerda implicava um rompimento aberto e radical com os valores e expectativas familiares em nome de uma causa social. Mas a liberação específica da condição feminina não era explicitamente colocada naquele momento pelos grupos de resistência à ditadura, e estes ofereciam certas ambiguidades em relação à militância das mulheres - e pelas próprias mulheres. As questões da vida cotidiana eram consideradas menores se comparadas às grandes questões da revolução, e as organizações de esquerda acatavam essa hierarquia. A situação torna-se ainda mais rígida com o endurecimento do regime militar após o AI-5, quando tais questões "foram ora simplesmente tachadas de contrarrevolucionárias e esquecidas, ora confinadas à invisibilidade dentro dos grupos de oposição clandestinos" (idem, p.45). De acordo com a autora, as mulheres que participavam politicamente da resistência à ditadura pertenciam a um grupo social economicamente privilegiado que, junto aos demais militantes, estavam empenhados numa "luta social" com sentido de "missão histórica" contra as enormes desigualdades sociais do país. No momento em que o autoritarismo do regime militar estabilizava-se de forma ainda mais dura, principalmente a partir da promulgação do referido Ato Institucional em dezembro de 1968, certos problemas encarados como "pessoais" eram minimizados diante de todos os problemas sociais enfrentados pelos brasileiros.

Os diversos grupos armados foram rapidamente dizimados pelo aparato repressivo da ditadura militar, cuja política de Estado era torturar e executar seus oponentes. A experiência da militância passou a incluir, além da clandestinidade, a tortura, a prisão, o exílio, a morte. ${ }^{11}$ É apenas nesse contexto posterior à resistência armada que

11 Cabe ressaltar que muitas pessoas foram torturadas, presas e mortas antes mesmo do AI-5. Basta citar o caso exemplar de Gregório Bezerra, militante do PCB, que fora preso e torturado na semana seguinte ao golpe de 1964, sendo arrastado e supliciado pelas ruas de Recife. Da mesma forma o exílio foi algo que ocorreu logo após o golpe, quando políticos foram cassados e militâncias sindicais e 
se pode realizar uma elaboração do momento histórico vivido. Nesse sentido, a experiência do exílio ofereceu elementos diferenciais na elaboração desse passado recente, principalmente às mulheres. $\mathrm{O}$ contato com o feminismo europeu, sobretudo com os movimentos de mulheres e feministas franceses que, nos anos 70, estavam no seu auge político, ${ }^{12}$ foi de grande importância para as exiladas. Nesse período, essas mulheres formaram o Círculo de Mulheres Brasileiras e Paris e o Grupo Latino-Americano de Mulheres em Paris, que contavam com a participação daquelas que militaram nas diversas organizações de esquerda e também com a presença das companheiras dos homens que haviam militado nessas mesmas organizações. ${ }^{13}$

O encontro com o feminismo francês - principalmente o de vertente marxista, em decorrência de suas vivências na esquerda brasileira -, a formação do Círculo e do Grupo Latino-Americano, a aproximação com a psicanálise: com esses elementos é possível afirmar que as mulheres tiveram um ganho significativo na elaboração que fizeram sobre o período anterior. Nesse trabalho de memória, realizado a partir das impressões e reflexões posteriores sobre o passado na militância, foram observadas as marcas das diferenças de gênero tanto na experiência política de seus grupos, como na experiência da repressão e tortura. Como consequência, muitas dessas mulheres tornaram-se feministas e atuaram numa nova forma de política, que fosse capaz de articular a reflexão em torno das questões interpes-

intelectuais perseguidas. Igualmente antes de dezembro de 1968 já havia se formado a Operação Bandeirantes, que daria lugar ao Doi-Codi. Mas é principalmente após o decreto desse ato (chamado de "golpe dentro do golpe") que a repressão aumenta drasticamente e, com ela, as sevícias. Outrossim, convém enfatizar que alguns grupos revolucionários já tomavam forma antes mesmo do golpe, como demonstra Daniel Aarão Reis Filho (2004; 2005).

12 A organização composta por militantes oriundas da esquerda francesa, conhecida como MLF (Mouvement de Libération des Femmes), tinha sua atuação influenciada pelo conteúdo antiautoritário e antiburocrático das mobilizações de 68, fazendo muitas vezes críticas e até rupturas com seus grupos de origem.

13 Para uma leitura mais aprofundada sobre a formação desses grupos e os conflitos que tiveram com certos setores da esquerda que também estavam no exílio, ver: Abreu, 2006. 
soais com a luta contra as condições objetivas da opressão social, como observou Maria Lygia Quartim de Moraes (1996). E é com essa bagagem prática e teórica que retornam ao Brasil a partir da segunda metade da década de 70 e, em maior número, após a Lei da Anistia de 1979.

Em 1975, ano definido pela ONU como o Ano Internacional da Mulher (e o primeiro ano da Década da Mulher), o general Ernesto Geisel já havia anunciado uma distensão política gradual e controla$\mathrm{da}$ - o que não significa dizer que a censura e a repressão estivessem extintas. ${ }^{14}$ Nesse ambiente, tal iniciativa da ONU abriu espaço para um movimento social que já agia, timidamente, nos bastidores. Pequenos grupos de mulheres já se reuniam desde 1972 em cidades, como o Rio de Janeiro e São Paulo, inspiradas no feminismo americano. Eram grupos com caráter bastante privado, fato compreensível não apenas por escolhas individuais de suas participantes, mas pelo próprio contexto em questão, que relacionava reuniões a atos subversivos. Com o reconhecimento pela ONU da "questão da mulher" como problema social, novos grupos políticos de mulheres passaram a existir abertamente. Jornais como o Brasil Mulher e o Nós Mulheres, que contavam com a participação feminina daquelas

14 As mortes do jornalista Vladimir Herzog, em outubro de 1975, e do operário Manoel Fiel Filhos, em janeiro de 1976, são os casos emblemáticos de tal situação. Para mais detalhes sobre esses casos, ver Dossiê Ditadura: mortos e desaparecidos políticos no Brasil (1964-1985), organizado pela Comissão de Familiares de Mortos e Desaparecidos Políticos e publicado em 2009 pela Imprensa Oficial do Estado de São Paulo. Além disso, a prisão de 513 estudantes em setembro de 1977, após a invasão policial da PUC-SP, onde ocorria uma Assembleia Estudantil simultaneamente ao III Encontro Nacional de Estudantes, também demonstra, de forma contundente, que a repressão estava em vigência. $O$ filme 77, realizado em 2008 pelo grupo Cultura e Política nos Anos 70, sob coordenação da professora Dra. Eliana Maria de Melo Souza, traz depoimentos de homens e mulheres que, estudantes no período em questão, participaram desse acontecimento. Ainda em 1977, foi promulgado o "Pacote de Abril", que fechou o Congresso Nacional temporariamente e fez alterações no processo eleitoral. Foi, portanto, um período marcado por tensão política no lugar da anunciada "distensão". 


\section{DANIELLE TEGA}

que ficaram no país e de outras que voltaram do exílio, foram publicados a partir desse período. Em suas páginas verificava-se a permanência das teses marxistas, dando importância à atuação na esfera pública e à centralidade da luta anticapitalista ao mesmo tempo, expondo uma preocupação marcante com os problemas políticos e sociais exacerbados pela ditadura militar. ${ }^{15}$

É também nesse momento histórico que surge o Movimento Feminino pela Anistia, que, "além da inquestionável importância da sua bandeira específica, colaborou significativamente para o avanço do movimento de mulheres”, como informa Maria Lygia Quartim de Moraes (1990, p.20). A participação no MFA foi estimulante para muitas mulheres, abrindo um espaço de militância que facilitava o acesso delas ao movimento feminista - não obstante a presidenta do MFA, Terezinha Zerbini, ter presença muito ativa em São Paulo e deixar claro a pouca importância que concedia à luta feminista. ${ }^{16}$

Nesse mesmo período, há a aproximação desses diversos grupos - alguns femininos, outros feministas - com as camadas populares, propiciando uma vinculação peculiar com diversas organizações de bairro, cuja disposição girava em torno de reivindicações de infraestrutura urbana básica, como água, luz, asfalto, esgoto etc. Para Cynthia Sarti (2004, p.4),

15 Para uma discussão aprofundada sobre ambos, ver: Moraes, 1990.

16 Em entrevista ao jornal Pasquim, Terezinha Zerbini faz a seguinte afirmação: "Vou ser muito franca. As feministas não devem pensar que descobriram a pólvora [...]. As feministas brasileiras procuram seguir as feministas inglesas ou americanas, o que não faz sentido num Terceiro Mundo, ou principalmente no continente latino-americano, onde nossos problemas são pão, teto, educação, saúde. [...] O feminismo é colocado no Rio, em São Paulo, em Porto Alegre e talvez em Belo Horizonte. Quem for falar em luta feminista no Nordeste sairá a pedradas". Apud Goldberg, 1987, p.27. Essa posição revela também como pensava boa parte da esquerda e dos problemas encontrados pelo feminismo no Brasil. Como sintetiza Céli Regina Pinto (2003, p.45), “O feminismo brasileiro nasceu e se desenvolveu em um dificílimo paradoxo: ao mesmo tempo em que teve de administrar as tensões entre uma perspectiva autonomista e sua profunda ligação com a luta contra a ditadura militar, foi visto pelos integrantes desta mesma luta como um sério desvio pequeno-burguês." 
Os grupos feministas, tendo a origem social de suas militantes nas camadas médias e intelectualizadas, em sua perspectiva de transformar a sociedade como um todo, atuaram articuladas às demandas femininas das organizações de bairro, tornando-as próprias do movimento geral das mulheres brasileiras, [...] constituindo-se em um movimento interclasses.

O período de 1975-1979 foi, portanto, marcado por uma intensa mobilização das mulheres brasileiras. Mas dado o contexto político-social no qual se manifesta, essa agitação foi marcada por uma "luta que se dividia entre o compromisso político contra a ditadura e as causas feministas, prevalecendo o primeiro nas negociações políticas", como afirma Lucila Scavone (2009). Tratava-se de um quadro complexo, pois ao mesmo tempo em que o feminismo protestava pelos direitos das mulheres, ele voltava-se principalmente à retomada das liberdades democráticas e ao compromisso de lutar contra a ditadura. $\mathrm{O}$ feminismo brasileiro, portanto, não deixava em segundo plano o momento histórico no qual se formou, consolidando naquilo que Anette Goldberg (1989) chamou de "um feminismo bom para o Brasil".

É principalmente a partir da anistia, com a saída de muitas militantes da prisão e com o retorno das exiladas, que questões propriamente feministas ganham espaço. Nesse sentido, os movimentos feministas propõem uma prática social que recusa as políticas hierarquizadas e centralizadas verticalmente. Como explica Eleonora Menicucci de Oliveira (2005),

Com o ideário da autonomia, [os movimentos feministas] tinham como princípio de atuação a máxima 'nosso corpo nos pertence', contra o determinismo biológico que naturalizava as questões sociais de direito e contra o determinismo econômico que, ao centrar na determinação econômica a libertação da mulher, operava uma separação binária entre a esfera da produção e da reprodução. Gerou-se a política do não, contra a opressão de sexo, a qual as teorias marxistas e os agrupamentos políticos de esquerda não haviam considerado até então. Voltava-se, assim, para as questões micro, localizadas na esfera da subjetividade, 
do privado, do desvendamento dos lugares onde as mulheres atuavam, como a casa, o doméstico, as relações sexuais; enfim, recriavam o significado do cotidiano através da possibilidade de recuperação da fala das mulheres. [grifos da autora].

A autora acrescenta que o feminismo brasileiro emerge em um contexto político marcado também pela desorganização dos movimentos políticos tradicionais, que foram barbaramente reprimidos pela ditadura. Nesse mesmo caminho, Marco Aurélio Garcia (1997, p.332) considera o feminismo como um produto da derrota das experiências de militância revolucionária, marcado pelo processo de autorreflexão, já que conseguiu construir um "diálogo (auto)crítico com o que haviam sido as esquerdas nos anos 1960/70, e ajudou a encontrar respostas para sua crise antes mesmo que surgissem as primeiras rachaduras do muro de Berlim."

A partir dessas ponderações, o feminismo passa a trabalhar com uma nova concepção de política, que leva à esfera pública e politiza questões até então tratadas como essencialmente femininas e, por extensão, relativas à esfera privada - isto é, questões não pertencentes ao campo masculino da política--, como as relativas ao corpo, ao desejo, à saúde e à sexualidade, temas presentes na passagem aos anos oitenta.

O feminismo da década de 80 foi marcado pela crescente partidarização e pela progressiva institucionalização. A presença de fundações internacionais que financiavam pesquisas relacionadas às "questões das mulheres", como a Fundação Ford, serviu de paradigma para a introdução de práticas e ideologias das organizações não governamentais (ONGs). As criações de Conselhos da Condição Feminina, de delegacias especiais para as mulheres e de serviços de atendimento às vítimas da violência (como o SOS Mulher) e à saúde da mulher (como o SOS Corpo) fazem parte desse mesmo movimento. É também nesse momento em que a abertura política possibilita a reativação e criação de partidos políticos, que contaram com a participação de algumas militantes feministas. Paulatinamente, os pensamentos de missão e de transgressão dos anos anteriores, 
formados a partir das ideias de revolução e de socialismo, foram redirecionados. Anette Goldberg (1989) afirma que:

[...] já não se preconizava uma participação na sociedade e/ou na vida política para mudar o sistema e abolir um Estado de classes (e também, eventualmente, de 'gêneros'), mas desejava-se participar das estruturas do Estado e suas ramificações para intervir nos rumos da sociedade brasileira, pra instaurar no país uma democracia na qual os cidadãos (entre os quais as mulheres) poderiam usufruir de políticas de bem-estar social. [grifos da autora]

Os grupos feministas propagaram-se em várias cidades brasileiras, atuando em associações profissionais, sindicatos e partidos. Temas fundamentais foram colocados em pauta, como a sexualidade, o aborto, a violência, entre outros. Mas, ao mesmo tempo, os grupos atomizavam-se, perdendo gradativamente seu caráter de movimento popular, direcionando-se para questões envolvidas com as preferências das agências financiadoras - situação que, gradativamente, implicava a especialização das feministas que atuavam nessas áreas.

Essa circunstância não ocorreu sem tensões no feminismo brasileiro. $\mathrm{O}$ processo de redemocratização gerou uma divisão entre as militantes, pois parte delas via possibilidade de cooptação nessa aproximação com a esfera estatal, e preferiam o caminho autônomo do movimento. Há que se ressaltar um importante momento de articulação entre as diferentes tendências a partir das atividades realizadas em conjunto pelo Conselho Nacional dos Direitos da Mulher, pelo feminismo autônomo e por outras organizações do movimento de mulheres de todo o país, que promoveram a campanha "Constituinte para valer tem que ter palavra de mulher!”. Utilizada como instrumento de mobilização das mulheres por suas reivindicações, essa articulação foi fundamental durante os trabalhos de preparação para a Assembleia Nacional Constituinte e no próprio período de trabalhos desta. Diversas reuniões foram organizadas e encontros marcados para apresentar as 
demandas à sociedade civil e aos constituintes, e grande parte de suas solicitações foram aprovadas. ${ }^{17}$

Nos anos seguintes, percebeu-se que o tipo de organização alastrado ao longo da década de 80 dominou o movimento feminista dos anos 1990, trançando um perfil de "feminismo profissionalizado" que agia sob a forma de prestação de serviços para mulheres vítimas de violência por meio de atendimento nas áreas jurídica e da saúde, redundando na despolitização do movimento. Como explica Maria Lygia Quartim de Moraes (2007, p.139), a autonomia e os novos métodos de fazer política foram esquecidos, transformando a atuação nas ONGs em "alternativas de trabalho, em estratégias de sobrevivência - um meio de vida".

Sim, ainda há resistência. Apesar do pequeno número de participantes, existem Coletivos Feministas autônomos em várias cidades do país. Também há expressões de artistas feministas, que se veiculam em artigos, livros e em outros tipos de manifestações culturais, como as jovens do Riot Grrrl. ${ }^{18}$ Contudo, falta uma rearticulação de forças que tenha como foco a emancipação de homens e mulheres nesta sociedade marcada pela reificação das relações sociais. Talvez seja o momento do feminismo brasileiro realizar um novo trabalho de memória: desta vez, sobre seu próprio movimento.

17 Como explica Ana Alice Alcântara Costa (2005, p.18), foi “através de uma ação direta de convencimento dos parlamentares, [...] conhecida como lobby do batom, [que] o movimento feminista conseguiu aprovar em torno de $80 \%$ de suas demandas, se constituindo no setor organizado da sociedade civil que mais vitórias conquistou. A novidade desse processo foi a atuação conjunta com a chamada 'bancada feminina'. Atuando como um verdadeiro 'bloco de gênero', as deputadas constituintes, independentemente de sua filiação partidária e dos seus distintos matizes políticos, superando suas divergências ideológicas, apresentaram, em bloco, a maioria das propostas, de forma suprapartidária, garantindo assim a aprovação das demandas do movimento."

18 Cultura juvenil originalmente vinculada à cultura punk, mas que possui fortes traços feministas ao associar música e política para denunciar e questionar relações desiguais de gênero. Ver: Melo, 2008. 


\section{Memória e relações de gênero nas telas}

A memória já entrelaçou os fios da ditadura militar e do feminismo. Falta urdir essas tramas ao cinema, pois o objeto de estudo deste livro são filmes que, produzidos após o regime autoritário, manifestem sua memória sobre a ditadura.

O passado pode ser reconstruído utilizando-se diferentes meios. Em matérias jornalísticas, em tratados sociológicos, em livros biográficos ou ficcionais, em museus, em filmes. Este livro privilegia o estudo dos filmes enquanto manifestações da memória e, como tais, possuem suas escolhas e seleções; seus lapsos, atos falhos e silêncios. Em estudo realizado com filmes cujos perfis aproximam-se ao aqui proposto, Mauro Luiz Rovai (2005) observa que, por meio do cinema, essas películas oferecem um modo de se relacionar com certos acontecimentos da história recente do país, produzindo uma perspectiva sobre o período histórico em tela:

[são filmes que] articulam, cada qual a seu modo, com certos recursos técnicos, uma ideia a respeito da vida social e política brasileira durante o período da ditadura militar. Destarte, merecem ser vistos como uma intervenção sobre essa realidade, uma forma de experimentar fatos e acontecimentos ainda muito presentes, pois se referem a um passado que ainda não passou, que permanece e incomoda.

O autor acrescenta que, cada qual a seu modo, são filmes que polemizam "um debate que é, em grande medida, sociológico". É sob esse prisma que procuro trabalhar, dado que não busco uma avaliação do tipo "filmes x realidade", mas verificar de que maneira são reconstruídas as diferentes interpretações sobre os eventos passados, observando o modo pelo qual as relações de gênero estão presentes nessas reavaliações. Sim, porque resgatar a saga da esquerda é também uma reavaliação - e, em alguns casos, uma auto-reavaliação - dos projetos políticos de uma geração.

Os filmes são, portanto, fenômenos políticos, o que deixa uma série de questões desde o início. Quais são as implicações políticas 
da manifestação da memória? Quais as disputas em torno da memória presentes nesse uso político do passado? De que modo os conflitos que habitam os eventos passados são reapresentados? Qual a importância disso para a dinâmica político-cultural do momento em que essas reavaliações são feitas?

Não penso ter respostas completas a todas as perguntas citadas. Mas talvez alguns vestígios possam ser encontrados no decorrer do estudo de cada filme, já que os paradoxos e tensões em torno das disputas da memória estão presentes naquilo que é explicitamente mostrado e também nos silêncios e falhas nas narrações. Assim, tanto no conteúdo como na forma do filme, há espaços onde as memórias entram em conflito, com diferentes propostas sobre os modos de vincular-se com o passado.

Essa consideração permite que se assumam, em primeiro lugar, atributos artísticos e ficcionais dos filmes para, num segundo momento, percebê-los em suas estreitas relações com a sociedade no qual se inserem. Pauto-me aqui nas observações de Antonio Candido (1969) que, ao examinar de forma particular a literatura, oferece elementos de análise para a obra de arte em geral. Segundo o autor, a obra é uma realidade autônoma naquilo que tem de especificamente seu - a precedência do estético -, e é a partir da própria obra que a análise deve ser iniciada. Porém, "o texto é integração de elementos sociais e psíquicos, [e] estes devem ser levados em conta para interpretá-lo” (p.35). Desse modo, a compreensão da obra não dispensa a atenção aos elementos inicialmente a ela externos, como o contexto sócio-histórico: tal consideração é "legítima e, conforme o caso, indispensável" (p.16).

Traduzindo essas reflexões em termos cinematográficos, trata-se de apreender o filme em si mesmo, investigando a disposição dos materiais visuais e sonoros que o dão forma, à busca dos sinais que contribuem para encaminhar o estudo ao contexto sócio-histórico. Diante disso, seguem algumas observações sobre o modo como o cinema é trabalhado nos estudos feministas/de gênero. 


\section{Considerações sobre gênero e cinema}

A teoria feminista do cinema teve e tem grande importância tanto nos movimentos feministas como nos estudos cinematográficos, fundando uma nova perspectiva de análise cujas abordagens acompanham os questionamentos e avanços dos estudos de gênero. Por esse motivo, penso ser importante destacar como autoras feministas trabalharam as questões da imagem e da sociedade.

Para Ann Kaplan, ao esconder o fato de que o filme é uma fabricação, o estilo dominante do cinema perpetua a ilusão de que se mostra algo natural aos espectadores. Em seu livro A mulher e o cinema: os dois lados da câmera (1985), a autora acrescenta que o cinema utiliza signos "carregados de uma ideologia patriarcal que sustenta nossas estruturas sociais e que constrói a mulher de maneira específica" (p.45). Desse modo, as narrativas dominantes no cinema, principalmente nas formas clássicas, apresentariam as mulheres adotando imagens que possuem uma categoria 'eterna' e que se repetem no essencial através das décadas:

Em primeiro lugar, parece-me que, embora certas questões relacionadas às mulheres estejam relacionadas a um contexto histórico específico, outras relacionadas ao matrimônio, à sexualidade e à família [...] transcendem as categorias históricas tradicionais (Kaplan, 1995, p.18).

Partindo desses pressupostos, e utilizando-se de referências da psicanálise e da semiótica, Kaplan concentra-se na questão do 'olhar masculino' - cujo poder dominador relegaria as mulheres à ausência e às margens do discurso histórico, subordinando seus desejos ao desejo masculino e limitando-as a certos padrões: são representadas de forma silenciosa ou frustrada; suas vidas são sacrificadas quando fazem qualquer atrevimento; e perdem características tradicionais (bondade, humanidade, maternidade) quanto estão no controle da ação, adotando o papel 'masculino'.

Apesar de enfatizar a "maneira como as mulheres são posicionadas nos filmes" (idem, p.50), observa-se em seus escritos pouca im- 
portância ao contexto histórico referente às imagens em movimento, e utilização de termos estagnados relacionados à essência das posições. Quando se pensa na relação entre cinema e sociedade, esse tipo de abordagem apresenta o perigo de tratar como natural 'papéis femininos' e 'papéis masculinos', impossibilitando perspectivas de mudanças - tanto sociais como de representação.

Outra feminista, Laura Mulvey, também faz uso da teoria psicanalítica para a interpretação cinematográfica. Em seu conhecido artigo Prazer Visual e Cinema Narrativo (1983), sustenta que o cinema "reflete, revela e até mesmo joga com a interpretação direta, socialmente estabelecida, da diferenciação sexual que controla imagens, formas eróticas de olhar e o espetáculo" (p.437). Tanto a subjetividade (com seus modelos já preexistentes de fascinação) como as formações sociais que a moldaram são consideradas elementos que reforçam a atração irresistível pelo cinema. $\mathrm{O}$ uso da psicanálise é apropriado enquanto instrumento político, na medida em que poderia demonstrar "o modo pelo qual o inconsciente da sociedade patriarcal estrutura a forma do cinema”. Conforme acrescenta,

A mulher, desta forma, existe na cultura patriarcal como o significante do outro no cinema, presa por uma ordem simbólica na qual o homem pode exprimir suas fantasias e obsessões através do comando linguístico, impondo-as sobre a imagem silenciosa da mulher, ainda presa a seu lugar como portadora de significado e não produtora de significado (Mulvey, 1983, p.438).

Ao discutir o prazer erótico no cinema e o lugar nele ocupado pela mulher, Laura Mulvey enfatiza que existem dois aspectos contraditórios das estruturas de prazer no olhar numa situação cinematográfica convencional: o primeiro, escopofílico, surge do prazer em usar uma outra pessoa como objeto de estímulo sexual, implicando uma separação entre a identidade erótica do sujeito e o objeto na tela; o segundo aspecto é desenvolvido através do narcisismo e da constituição de um ego, surgindo pela identificação com a imagem vista por intermédio da fascinação. Dessa situação, 
conclui que o cinema parece ter colocado em prática um devaneio específico de realidade, no qual há uma contradição entre a libido e o ego: o olhar, mesmo que agradável na forma, pode ser ameaçador no conteúdo; e a mulher, sob o aspecto de representação/ imagem, mantém esse paradoxo consolidado. A autora elabora, assim, uma crítica da imagem como um produto no qual prevalece o olhar masculino, sendo a imagem da mulher um objeto passivo do olhar:

Num mundo governado por um desequilíbrio sexual, o prazer no olhar foi dividido entre ativo/masculino e passivo/feminino. O olhar masculino determinante projeta sua fantasia na figura feminina, estilizada de acordo com essa fantasia. Em seu papel tradicional exibicionista, as mulheres são simultaneamente olhadas e exibidas, tendo sua aparência codificada no sentido de emitir um impacto erótico e visual de forma a que se possa dizer que conota a sua condição de 'para-serolhada' (idem, p.444).

Ainda trabalhando com a questão do posicionamento da mulher na narrativa fílmica, Laura Mulvey destaca que há duas saídas para essa representação. A investigação e desmistificação do mistério feminino são contrabalanceadas com a desvalorização, punição ou redenção da mulher; ou com sua substituição e transformação em um fetiche - o que explicaria o culto da star feminina. Para a autora, o que diferencia o cinema em seu potencial voyeurista de outras formas de manifestação artística é que este constrói o modo pelo qual a mulher deve ser olhada, ou seja, "é o lugar do olhar e a possibilidade de variá-lo que definem o cinema” (idem, p.452). Nesse sentido, enfatiza a questão da construção do filme:

Jogando com a tensão existente entre o filme enquanto controle da dimensão do tempo (montagem narrativa), e o filme enquanto controle das dimensões do espaço (mudanças em distância, montagem), os códigos cinematográficos criam um olhar, um mundo e um objeto, de tal forma a produzir uma ilusão talhada à medida do desejo. São estes códigos cinematográficos e sua relação com as estruturas formativas exter- 
nas que devem ser destruídos no cinema dominante, assim como o prazer que ele oferece deve também ser desafiado (1983, p.452).

Embora dê importância às formas de construção fílmicas, não há em seu texto indicações que manifestem a possibilidade de mudanças nos sistemas de escolhas da narrativa clássica. Assim como E. Ann Kaplan, Laura Mulvey faz uso de oposições binárias, o que inviabiliza uma reflexão mais complexa no tratamento das convenções de feminilidades e masculinidades - sejam estas sociais ou de representação. Sua abordagem apresenta o risco anteriormente apontado de universalizar questões socialmente estruturadas, pois utiliza conceitos estanques de masculino e feminino.

Cabe ressaltar que os trabalhos dessas autoras foram realizados num contexto específico. Como Laura Mulvey esclarece em entrevista concedida à Revista de Estudos Feministas (2005, p.351-362), seu artigo tinha propósitos mais políticos que acadêmicos, e fora escrito "mais sob o impacto do movimento de mulheres do que dos estudos de cinema", ${ }^{19}$ cuja preocupação central era a produção de uma crítica feminista ao cinema narrativo tradicional tendo como alternativa a constituição de um contracinema.

Trabalhando numa perspectiva que questiona os pressupostos anteriores, Teresa de Lauretis problematiza a ênfase no sexual, já que esse tipo de análise dificulta a articulação das diferenças entre as mulheres e nas mulheres. Sua crítica vai ao encontro das propostas de Joan Scott (1990, p.71-99), para a qual é necessário derrubar “o caráter fixo e permanente da oposição binária”. A análise de Teresa de Lauretis assinala a necessidade de estudar as imagens para compreender a visibilidade ou a ocultação de questões relevantes na representação social, levando em consideração a complexa relação entre o mundo construído pelos filmes e a sociedade. Ao observar os debates que molduram as imagens das mulheres a posições fixas, afirma que:

19 Amplamente divulgado e traduzido, este ensaio de Laura Mulvey ultrapassou a intenção inicial e tornou-se referência no âmbito de estudos cinematográficos. 
Tais discussões sobre as imagens da mulher dependem de uma oposição muitas vezes rasa entre positivo e negativo, a qual não é apenas desconfortavelmente próxima a estereótipos populares, tais como mocinhos versus bandidos ou boa moça versus garota má, como contêm ainda uma implicação menos óbvia e mais arriscada. Pois supõe que as imagens são diretamente absorvidas pelos espectadores e que cada imagem é imediatamente legível e significativa em si mesma e a partir de si mesma, independentemente do seu contexto ou das circunstâncias da sua produção, circulação e recepção (De Lauretis, 2003, p.4).

Dessa forma, destaca que o contexto da prática social deve ser examinado, e enfatiza que as imagens devem ser consideradas "como (potencialmente) férteis em contradições, tanto no processo subjetivo quanto no processo social" (idem, p.6). Sua análise relaciona os movimentos que perpassam filme e sociedade, e recupera do cinema o conceito de space off como o espaço que não está visível no quadro, mas que pode ser deduzido a partir dos elementos manifestos na imagem - e que existem simultaneamente ao espaço representado. A proposta de Teresa de Lauretis é um movimento "a partir do espaço representado por/em uma representação, por/em um discurso, por/em um sistema de sexo-gênero, para o espaço não representado, mas implícito (não visto) neles" (De Lauretis, 1994, p.237). Essa abordagem permite problematizar as relações de poder, que são mais complexas que a dicotomia masculino/feminino, além de oferecer ferramenta aos estudos fílmicos.

Numa perspectiva próxima às questões acima apresentadas, Miriam Adelman (2003) faz um estudo sobre a forma pela qual as convenções de feminilidades e masculinidades são retomadas pelo cinema. Para a autora, esse tipo de análise pode ser feito a partir de um exame que contempla tanto a imagem construída quanto o contexto social de sua produção:

[...] examinar as relações de gênero representadas no cinema significa transitar entre a obra cinematográfica e o mundo das relações sociais 'fora do cinema'; é um ir e voltar, pois o cinema, como toda produção cultural, reflete práticas e significados sociais ao mesmo tempo 
em que os constrói e, para usar o termo corrente, os 're-significa' (idem, p.86).

Miriam Adelman aproxima-se, assim, da concepção de que os filmes articulam uma ideia de vida social e intervém nessa mesma realidade; não só fazem parte, mas ajudam a produzir esta realidade que, por sua vez, é sempre representação. Ao indagar como se manifestam as novas perspectivas sobre as mulheres e as relações de gênero no cinema, Miriam Adelman compartilha das posições de possibilidades de mudança nas representações, ponderando o fato de algumas imagens cederem espaços a novos tipos de representações e buscando saber quais alterações ocorrem com o rompimento do 'olhar masculinista'.

Para finalizar esse debate entre autoras feministas que estudam o cinema, cabe citar o trabalho de Ella Shohat. Em entrevista concedida à Revista de Estudos Feministas (2001, p.147-163), afirmou que se sentia fora da abordagem dominante no discurso feminista - a psicanálise -, pois este não oferecia abertura para discutir as questões de raça, classe e estratificação nacional. A autora questiona os pressupostos que universalizam o 'feminino' e o 'olhar masculino', e rediscute a teoria clássica feminista sobre o cinema ao articular as teorias de gênero com a crítica pós-colonial, mostrando as complexidades das relações de dominação - que se reproduzem também entre as mulheres:

Dizer que as identidades não são apenas biológicas, mas são construídas, não significa que elas estejam desprendidas das instituições e das forças políticas e econômicas. [...] por isso que a questão da performance joga um papel importante nas recentes teorias sobre a construção de identidades. As identidades não são essenciais, mas são "performadas" e construídas (idem, p.153).

Nesse sentido, a perspectiva de Ella Shohat acrescenta à discussão sobre o cinema elementos relacionados ao cruzamento entre raça, gênero, nação e sexualidade, propondo métodos alternativos de aná- 
lise feminista que dão destaque ao contexto sócio-histórico das imagens construídas. Para ela, o fato de que nada escapa da mediação das representações implica um retorno: "as representações também têm um impacto no mundo, [nas] identidades projetadas, [nas] identificações sociais e filiações culturais" (idem, p.155).

O pensamento feminista sobre o cinema avançou em diferentes aspectos. Mesmo que minha proposta não esteja filiada a uma abordagem específica, as diferentes interpretações sobre gênero e cinema possibilitam um exame mais aprimorado sobre o modo pelo qual o cinema reconstrói as relações de gênero. Penso que, agora, podemos ir aos estudos dos filmes selecionados. 



\section{2 \\ VOZES FEMININAS EM CENA}

A manifestação da memória da resistência à ditadura civil-militar brasileira é formada por situações inquietantes quando vistas a partir dos estudos de gênero. Após a segunda metade da década de 70 , a chamada abertura lenta, segura e gradual, mesmo que de forma conturbada e com a permanência da repressão e, em muitos casos, da censura, permitiu uma esfera pública na qual narrativas e relatos, até então contidos, puderam ser incorporados. Isso não implica, necessariamente, uma contraposição binária entre "história oficial" x "narrativa da sociedade", mas sim a possibilidade de múltiplos atores sociais e políticos estruturarem seus relatos do passado, expressando, ao fazê-los, seus projetos e expectativas políticas para o futuro.

Assim, no final dos anos 1970 e no início dos anos 1980, ocorre o chamado boom de livros autobiográficos, como são os casos de Em câmera lenta, de Renato Tapajós; O que é isso, companheiro?, de Fernando Gabeira; e Os carbonários, de Alfredo Sirkis. ${ }^{1}$ Além des-

1 Para uma importante discussão a respeito dos alcances, limites, significados político, social e cultural da obra desses três autores e também de Reynaldo Guarani, destaco o livro Os escritores da guerrilha urbana: literatura de testemu- 
ses títulos, diversos outros são publicados nesses anos e nos seguintes. Em levantamento bibliográfico realizado por Marcelo Ridenti (2001, p.257-295), constata-se a presença de mais de 230 livros ou teses que, publicados até meados de 2001, abordam direta ou indiretamente a luta das esquerdas armadas contra a ditadura no Brasil nas décadas de 60 e 70. Mesmo que não se pretenda completo, esse quadro traz informações importantes: cerca de $15 \%$ dos títulos citados são autobiográficos ou baseados em memórias do período de resistência; dentre esses, nenhum escrito por mulher. Essa situação leva a crer que há uma especificidade de gênero nos relatos sobre a ditadura no Brasil, pois, mesmo nas contramemórias, há ainda um domínio da fala e da escrita masculinas. ${ }^{2}$

As vozes femininas foram e ainda são abafadas. Certamente existem livros sobre a participação política feminina. Destaco o pioneiro Memória das mulheres do exílio, organizado por Albertina de Oliveira Costa (1980), realizado a partir do recolhimento de diversos depoimentos de exiladas na Europa. Há também dois livros resultantes de trabalho de mestrado: Mulheres, militância e memória, de Elizabeth Ferreira Xavier (1996), e A resistência da mulher à ditadura militar no Brasil, de Ana Maria Colling (1997). Outro livro com depoimentos diversos é o do jornalista Luiz Maklouf Carvalho, Mulheres que foram à luta armada (1999). Sem contar Iara-reportagem biográfica, livro de Judith L. Patarra sobre a vida de Iara Iavelberg, militante da Polop e, depois, da VPR. Além desses títulos, diversos artigos foram publicados em revistas acadêmicas e coletâneas diversas. Mas o que quero registrar é a dificuldade em encontrar narrativas autobiográficas ou narrativas ficcionais baseadas nas memórias das mulheres que participaram da resistência à ditadura e escritas por elas - algo semelhante ao que Márcio Seligmann-

nho, ambivalência e transição política (São Paulo: Annablume/Fapesp, 2008), fruto da dissertação de mestrado de Mário Augusto Medeiros da Silva.

2 A historiadora uruguaia Graciela Sapriza (2009) afirma que essa situação se repete em seu país, onde a literatura sobre o período da ditadura é praticamente monopolizada por homens. 
Silva (2003) chama de literatura do testemunho, considerando a escrita como uma das possibilidades de elaboração do luto; ou a arte como um processo de rememoração.

Dada essa ausência no âmbito da literatura, encontra-se no cinema um filme dirigido, roteirizado e produzido por uma ex-militante de um grupo guerrilheiro. Trata-se de Que bom te ver viva, primeiro longa-metragem da cineasta Lúcia Murat, que aborda a sobrevivência à ditadura militar de oito mulheres que participaram da resistência política ao regime repressivo. Imagens em movimento, vozes, música e fotos de arquivo são combinadas na construção de uma memória sobre esse passado e, nesse sentido, entram em debate com outras memórias.

A escolha de Que bom te ver viva justifica-se, nesse sentido, como eixo de análise deste livro. É a partir dele que procuro trabalhar questões referentes às relações sociais após a ditadura em uma sociedade onde ainda se encontram as feridas do período anterior e, com isso, fazer comparações e ligações a outros filmes que tratem também da resistência à ditadura no Brasil. Estamos, assim, no campo de conflitos e disputas em torno da memória, e o estudo dos elementos que compõem cada narrativa fílmica é um importante instrumento para verificar como se dá tal debate.

Quando cursava economia, Lúcia Murat engajou-se nas atividades do Diretório Acadêmico e no movimento estudantil. Em 1968, com 17 anos, foi presa pela primeira vez ao participar do famoso Congresso da UNE em Ibiúna. A partir daí, passou a ser considerada uma pessoa "marcada" pelos agentes da repressão. Quando o AI- 5 entrou em vigor, foi novamente presa em São Paulo por uma semana. Desse momento em diante, caiu na clandestinidade e abandonou a vida legal: "Minha vida se definia pela chamada revolução, nada mais existia”, diz em entrevista à Lúcia Nagib (2002, p.323). Permanece ligada à organização guerrilheira MR-8 até meados de 1971, quando é novamente presa:

Em setembro de 1969, depois do sequestro do embaixador americano, entrei na clandestinidade total. Foi um período negro em mi- 
nha vida. Fiquei um tempo na Bahia. Descoberta, consegui não ser presa. Fiquei, por três meses, trancada dentro de um apartamento até conseguir ser levada para o Rio. Cercada pouco depois, em abril de 1971, fui presa e torturada nos dois meses e meio em que estive no Doi-Codi. Uma experiência que me marcou para o resto da vida. (idem, ibidem).

Esses sinais estão presentes em boa parte de seus filmes que, direta ou indiretamente, tratam da experiência da violência. ${ }^{3}$ Mais que isso, tendo em vista a importância da arte para o processo de elaboração, a cineasta faz a seguinte af irmação numa entrevista ao jornalista Heitor Augusto (2008):

Acho que questões como a da violência vão ficar eternamente pra mim. De certa maneira, apesar de o cinema ser uma grande indústria onde gira muito dinheiro, acabou sendo uma maneira de eu sobreviver a tudo isso discutindo essas questões. [...] Eu acho que a arte tem muito a ver com o sujeito. Não que ela seja realisticamente autobiográfica, mas tem a ver com seus questionamentos, angústias. Ou seja, é trabalho autoral. O meu cinema é autoral, eu não faço cinema sob encomenda, então inevitavelmente eu estou presente [...].

Sob esse prisma, a relação da diretora com o cinema passa pela necessidade que sentiu de refletir sua experiência na resistência à ditadura no Brasil. Quando preparava Que bom te ver viva, pretendia lançá-lo em 1988 para coincidir com os 40 Anos da Assinatura da Declaração dos Direitos Humanos da ONU. Como consta no roteiro, Lúcia Murat (1987) caracteriza esse filme como "de grande importância para a história do Brasil, porque pretende resgatar uma

3 Filmes como Doces poderes (1997), Brava gente brasileira (2000) e Quase dois irmãos (2004), além de Que bom te ver viva (1989), são os exemplos nos quais a questão da violência aparece de forma mais manifesta na obra de Lúcia Murat. Embora me pareça um caminho interessante, fugiria da proposta deste livro fazer uma análise de toda a obra da cineasta. 
parte da memória nacional de difícil assimilação”. O título provisório era Mulheres Torturadas, mas o lançamento ocorreria apenas em junho de 1989, no Festival de Gramado. Marcada pelas cicatrizes de um período ainda próximo ao contexto do filme, a cineasta conta como surgiu o esboço de fazer Que bom te ver viva:

Certo dia, acordei com a ideia do que viria a ser Que bom te ver viva, uma possibilidade de trabalhar com documentário e ficção, ego e superego, intimidade e distanciamento. Acordei com a estrutura de um filme sobre as mulheres torturadas na época da repressão, que depois fui depurando. A estreia de Que bom te ver viva foi muito profunda, emocionante, não só para mim como para todos que participaram do filme. Foi uma sensação prazerosa; pela primeira vez, depois de tanta violência sofrida, podíamos falar. A repercussão do filme foi enorme. (Nagib, op. cit., p.324).

E foi mesmo. Mas antes de comentar sobre a euforia com a qual o filme foi recebido, convém enfatizar uma questão importante informada pela cineasta: no período de realização do filme, a repressão ainda estava próxima, a ponto de ter recebido ameaças veladas antes de seu lançamento. Tal situação não se repetiu após sua primeira exibição em Gramado, quando foi qualificado como "um filme fundamental”, "que resgata fatos, memórias e sabe como trabalhar essa investigação na direção do futuro", sendo "impossível ver sem se emocionar", embora seja "antes de tudo cinema, bem elaborado, estruturado". ${ }^{4}$ Sem chegar a tempo de concorrer ao prêmio do evento, participou na categoria hors-concours e foi considerado "o filme impacto do Festival". ${ }^{5}$

4 Citações retiradas do press-release do filme, preparado após a sessão especial para a imprensa que cobria o Festival de Gramado. Comentários respectivamente de Susana Schild (Jornal do Brasil), Edmar Pereira (Jornal da Tarde) e, nas duas últimas apreciações, Helena Salem (Última Hora).

5 Título do artigo publicado por Edmar Pereira (1989) na época do lançamento do filme Que bom te ver viva. 
Que bom te ver viva mistura ficção e documentário para abordar a tortura durante a ditadura no Brasil, mostrando como suas vítimas sobreviveram e como encararam aquele período de violência 20 anos depois. Na parte documental, oito mulheres que participaram da militância política e viveram situações de tortura são entrevistadas; na parte ficcional, uma personagem anônima interpretada pela atriz Irene Ravache enuncia diversos monólogos que são intercalados aos testemunhos. Para diferenciar a ficção do documentário, Lúcia Murat optou por gravar os depoimentos das ex-presas políticas em vídeo com um enquadramento em primeiro plano, capaz de enfatizar emoções e detalhes. O cotidiano dessas mulheres é filmado à luz natural, como se representasse a vida aparente. E a luz teatral é utilizada nos monólogos, uma espécie de discurso inconsciente da narradora.

Após o reconhecimento em território brasileiro, Lúcia Murat foi chamada para apresentar seu filme em diversos países. Mas o cenário nacional ficou completamente desfavorável menos de um ano após os aplausos de Gramado: em março de 1990, foram publicados pelos jornais brasileiros o pacote de medidas provisórias e decretos do então recém-empossado presidente Fernando Collor de Mello. Além da extinção de leis de incentivos culturais, houve o fechamento de entidades de administração pública federal, como a Embrafilme. Desse modo, a veiculação de Que bom te ver viva foi interrompida, e o filme ficou trancado nas dependências dessa instituição. Com os inúmeros convites para participar em festivais internacionais, Lúcia Murat diz ter feito uma ação para recuperá-lo:

[o filme] estava preso na Embrafilme. Eu me senti novamente na guerrilha. Nós conseguimos entrar lá dentro com a ajuda de um funcionário amigo, que se propôs a assinar um documento como se tivéssemos pedido o filme duas semanas antes do desmantelamento da Embrafilme. Ele assinou o pedido falso, e eu tive que pegar a cópia e sair pelos fundos do prédio, onde um amigo me esperava. Quase uma ação armada! (Bezerra, 2005, p.20) 
Após essa façanha, o filme foi distribuído internacionalmente pela ONG feminista Women Make Movies, ${ }^{6}$ que auxilia a difusão de filmes feitos por e/ou sobre mulheres. Nesse ponto, cabe uma observação. Lúcia Murat rejeita que seu filme seja concebido comofeminista. Em entrevista ao jornal $O$ povo ${ }^{7}$ publicada em março de 2007, a cineasta fez a seguinte declaração:

O Que bom te ver viva, muita gente olha como se fosse feminista $\mathrm{e}$ não deve. Ele se constrói com um componente feminino muito forte porque ele fala muito da minha pessoa. As pessoas perguntam por que eu só escolhi mulheres para dar depoimento. Não foi uma opção feminista, mas sim uma opção dramatúrgica. Queria fazer o filme como se fosse um ciclo que se repetisse; cada depoimento meio que introduzindo um outro depoimento mas dentro do mesmo universo, sendo que a Irene Ravache representava o superego em todo esse universo. Obviamente, ela representava também o superego do universo feminino dentro daquela situação de violência. Se eu colocasse um homem ali eu ia romper com essa minha intenção dramática de fazer esse círculo vicioso. A opção foi então dramática, mas provinha do fato de que o filme tinha um caráter autobiográfico muito forte e de eu ser mulher, mas não de uma decisão de fazer um filme sobre mulheres. [grifos meus]

Caso semelhante ocorre com a cineasta Ana Carolina, a qual recusa que seus filmes sejam caracterizados como feministas. ${ }^{8}$ Acredito que valha a pena uma pesquisa para verificar o motivo pelo qual se dá tal rejeição, quando as diretoras sequer comentam a possibilidade de diferentes níveis de ligação entre seus filmes e o pensamento feminista - e, nesse sentido, caberia compreender o que elas entendem por feminismo. Como já observou Rachel Soihet (2008, p.191-208), a oposição ser feminista x ser feminina, quando incorpo-

6 Esta organização ainda está ativa e suas atividades podem ser acompanhadas pelo site www.wmm.com.

7 A entrevista completa pode ser lida em http://www.opovo.com.br/opovo/ vidaearte/676051.html

8 Para um belo estudo da trilogia de Ana Carolina, ver: Esteves, 2007. 
rada em discursos de mulheres de diferentes classes sociais, reflete o modo distorcido pelo qual a categoria feminista foi por elas apropriada, atribuindo significados por vezes jocosos ao ser feminista. Contudo, neste livro, limito-me a observar qual o diálogo que o filme faz com questões feministas, centrando-me na análise a partir da obra, ou seja, sem fundamentar-me, a princípio, no que diz a própria cineasta a esse respeito.

E para finalizar esta breve apresentação do filme, mais um assunto merece ser sublinhado. Que bom te ver viva já foi objetivo de alguns trabalhos acadêmicos, como o artigo de Edson Luis de Almeida Teles (2004), a dissertação de Rodrigo de Moura e Cunha (2006) e a tese de Maria Luiza Rodrigues Souza (2007). Em todos esses trabalhos, os temas da memória e do esquecimento estão presentes, embora as referências teóricas de análise nas quais se baseiam sejam diferentes. ${ }^{9} \mathrm{O}$ diferencial na minha proposta de análise está na tentativa de articular os estudos de memória ao pensamento feminista e aos estudos de gênero para, com isso, verificar as tensões e paradoxos presentes na construção da memória, levar em conta como certas convenções de feminilidades e masculinidades são trabalhadas, e fazer a comparação com outros filmes a partir dessa mesma perspectiva.

\section{O difícil equilíbrio entre não conseguir esquecer e continuar vivendo}

Em uma pequena sala com poucos móveis, uma mulher está sentada sobre o chão. Nesse espaço cênico teatral, ela retira uma fita VHS do aparelho de videocassete e insere outra. Somos encaminhados às

9 O primeiro trabalho tem como referência os escritos de Hannah Arendt; o segundo, é feito em grande parte com base em Friedrich Nietzsche; já o terceiro leva em consideração os pensamentos de Michael Taussing e Maurice Halbwachs. Nos três casos há, em maior ou menor grau, referência a Walter Benjamin. 
imagens que aparecem no início ou no fim de uma gravação, com aquelas faixas coloridas verticais, enquanto ouvimos uma voz em tom melancólico, que logo sabemos tratar-se de seu pensamento:

Vejo e revejo as entrevistas e a pergunta permanece sem resposta. Tudo começa exatamente aqui, na falta de resposta. Acho que devia trocar a pergunta: ao invés de 'por que sobrevivemos', 'como sobrevivemos'?

Nesse momento, o filme já nos deu algumas informações. Antes mesmo desta primeira sequência, há uma legenda introdutória escrita em vermelho num fundo preto, a respeito do golpe de 1964 e do AI-5 em 1968, alertando sobre a prática sistemática da tortura aos opositores do regime. Na última frase, o assunto que o filme pretende abordar - "Esteé um filme sobre os sobreviventes destes anos" - e, na legenda seguinte, um epílogo citando o autor Bruno Bettelheim: "A psicanálise explica por que se enlouquece, não por que se sobrevive".

É sobretudo a partir do recurso da metalinguagem da primeira sequência, quando a personagem vivida pela atriz Irene Ravache, ao retomar a indagação já presente no epílogo, diz ter visto e revisto "as entrevistas", que passamos a compartilhar do labirinto da memória construído pelo filme. Ela se refere às entrevistas realizadas pela própria diretora do filme, e que serão apresentadas como depoimentos entre um monólogo e outro que interpreta. É um momento paradoxal, pois se trata de um tempo fílmico que é inicial para os espectadores, que ainda não viram as entrevistas citadas; mas que já possui algumas considerações finais em que a cineasta fala por meio daquela mulher sentada, e age por intermédio dessa personagem quando nos introduz aos depoimentos após inserir a fita no videocassete.

A ambivalência do tempo-que também permeia outros momentos do filme - tem, nessa primeira sequência, um duplo efeito: permite-nos trabalhar com a hipótese de que a personagem de Irene Ravache é o alter ego de Lúcia Murat; e nos dá pistas com sua "conclusão inicial” de que vai tratar de um assunto que é próprio do trauma: a falta de resposta, a dificuldade em verbalizar o ocorrido. 
Os monólogos da personagem têm a virtude de pôr em palavras e imagens certos incômodos que não são abordados pelas depoentes, como as questões que relacionam sexualidade e prazer. Sendo a narradora do filme, sua atuação é intercalada aos depoimentos, e seu posicionamento cênico encara câmera em diversas situações, provocando o/a espectador(a). O fluxo de sua consciência demonstra inquietação e perturbação, tendo como um dos sintomas a invocação de um tempo mesclado, onde passado, presente e futuro precisam ser decifrados. Assim, o tom autobiográfico é somado aos momentos performáticos dos monólogos, atraindo-nos para as representações subjetivas dos acontecimentos traumáticos.

Para entender melhor essa composição, que mistura ficção e documentário, voltemos ao filme. Estamos ainda na primeira sequência, a personagem de Irene Ravache fala sobre as entrevistas. Ainda na sala, toca o telefone. Ela atende, e pelas suas palavras entendemos que alguém a avisa sobre uma reportagem jornalística que indica que ela sofreu tortura sexual - sinalizando um tema presente em outros momentos do filme. Toca o telefone novamente, é sua mãe ligando para saber a respeito dessa mesma reportagem.

Após essa conversa, o filme apresenta imagens de arquivo, jornais e fotos. Em close, conhecemos a primeira entrevistada. Uma música instrumental acentuada enfatiza o caráter emotivo de um pequeno trecho de seu depoimento. A imagem é, então, congelada, para depois ser diminuída a ponto de dividir a tela com uma legenda que contém informações sobre a depoente. ${ }^{10}$ Trata-se da educadora Maria do Carmo Brito, que tem 44 anos e dois filhos; foi comandante da VPR, presa e torturada durante sessenta dias, passando dez anos no exílio. O mesmo recurso é utilizado para as demais depoentes, exceto uma que preferiu não se identificar. Nos primeiros instantes do filme, portanto, já são feitas as apresentações das "sobreviventes", as quais a cineasta se refere na legenda da primeira tela do filme.

10 Cito os dados apresentados na tela, pois, a partir deles, algumas observações são tecidas no decorrer deste livro. 
Num primeiro bloco, conhecemos, além de Maria, Estrela Bohadana (40 anos, militante do POC, presa e torturada no Rio de Janeiro e em São Paulo, dois filhos, doutora em Filosofia), Pupi (Maria Luiza Garcia Rosa, 37 anos, participante do movimento estudantil, presa e torturada três vezes, dois filhos, médica sanitarista), Rosalina Santa Cruz (43 anos, presa e torturada, três filhos, professora). Num segundo bloco, são apresentadas: uma militante que preferiu não se identificar (quatro anos de militância, quatro anos de cadeia, sem filhos - seu rosto é substituído por uma vela), Criméia Schmidt de Almeida (41 anos, sobrevivente da Guerrilha do Araguaia, um filho, enfermeira), Regina Toscano (40 anos, torturada ao ser presa em 1970, três filhos, educadora) e Jessie Jane (37 anos, detida em 1970, três meses encarcerada nos órgãos de tortura, nove anos de prisão, uma filha, historiadora).

Embora esses apontamentos possam ser entendidos como didatismo por parte da diretora - que buscaria, nesse sentido, mostrar informações suficientes para que qualquer espectador, mesmo o menos familiarizado com o tema proposto pelo filme, consiga localizar historicamente cada personagem apresentada -, trazem dados importantes para se pensar a resistência feminina à ditadura: $\mathrm{o}$ perfil das mulheres apresentadas no filme não deixa de revelar o perfil das militantes do período de uma forma geral. Como exposto no capítulo anterior, ao observar dados referentes às organizações de esquerda, Marcelo Ridenti (2003) observa que, dentre as mulheres que participaram dos grupos armados, cerca de $75 \%$ pertenciam às camadas médias intelectualizadas. Grande parte delas, como a própria cineasta, iniciou a militância no movimento estudantil e, depois, ligou-se à luta armada.

A forma fílmica escolhida pela cineasta, que filma em close todos os depoimentos, coloca literalmente em primeiro plano algo que, até então, não aparecia com a atenção merecida, que é a participação política das mulheres na luta contra a ditadura militar. A proximidade da câmera expande na tela esses sujeitos históricos: quem são, como militaram, como (sobre)vivem. Que bom te ver viva faz um importante diálogo com o pensamento feminista ao manifestar as 
trajetórias ainda pouco exploradas e dar visibilidade a depoimentos até então escondidos. Reconstrói a memória abrindo espaço para as vozes das mulheres na elaboração do passado traumático. Cabe, agora, verificar a partir de quais pontos o filme faz esse exercício de memória.

\section{Tentando entender a loucura latente daquela procissão}

O filme de Lúcia Murat usa a entrevista para juntar relatos diferentes numa única história. $\mathrm{Na}$ verdade, o filme é menos sobre 'a história' que sobre 'memória', menos sobre a história dos vencedores e mais sobre a história dos vencidos, das versões e das feridas ainda pouco traduzidas em arte.

Os depoimentos são tramados com ênfase no discurso subjetivo sobre o valor duradouro de um momento específico: a tortura política. A profundidade psicológica percorre todas as falas, como podemos observar na declaração de Pupi:

Quando eu fui presa, eu tinha uma sensação muito grande de poder. Como eu acreditava muito no que estava fazendo, acreditava que a gente ia conseguir transformar o mundo, eu achava que os torturadores e a polícia eram seres quase inferiores. Eu tinha muita segurança em mim e achava que ia segurar a situação. A tortura foi indo e eu cheguei na minha situação-limite.

Pupi acrescenta que a violência da tortura psicológica era muito forte. Em algumas circunstâncias, com o intuito de obter informações, o torturador fingia estar apaixonado. Jessie Jane, presa quando tentava sequestrar um avião, também destaca o drama da tortura psicológica e a sensação de impotência ao saber da prisão de outras mulheres de sua vida: irmã, mãe e sogra foram também presas, sendo que a primeira foi torturada em sua frente. "Ter sobrevivido sem enlouquecer foi uma vitória”, afirma.

Regina comenta o que ocorreu quando foi presa após uma perseguição: "procuraram arma dentro de minha xoxota. Sabiam que não 
tinha; foi mesmo para me humilhar". Grávida, perdeu o filho. Acredita "que a vida continua". Mas se percebe que a continuidade é de outra qualidade: a dificuldade de tratar desse assunto é vista claramente em sua face, em suas palavras trêmulas, que contrabalançam com o largo sorriso ao lado dos filhos e das amigas. Situação que a narradora percebe como um "quebra-cabeça difícil de encaixar", cujas peças parecem ser montadas com uma informação adicional que as imagens não mostraram: durante a entrevista, Regina estava com seu remédio de epilepsia ao lado o tempo todo, com medo de uma nova crise ao tocar no assunto.

Rosalina cita algumas sevícias as quais fora submetida: apanhou de diferentes formas, passou pelo choque elétrico e pelo pau-de-arara. Chegou a pedir que o torturador a matasse, mas a relação de poder estabelecida naquele momento é revelada na frase do algoz: "Não mato, faço o que eu quiser". Essa situação da tortura é entendida por Marilena Chauí (1987, p.37) a partir de um paradoxo fundamental:

Destituir alguém de humanidade e de subjetividade, produzir um outro sujeito no lugar do sujeito real, pois dessa 'subjetividade' criada depende a ação e a sanidade do próprio torturador que só persiste se a 'coisa' puder ser convertida em 'sujeito' para reconhecê-lo. Pois o reconhecimento, marca essencial da intersubjetividade, é a condição e o fim da humanidade de cada um e de todos.

Além dos depoimentos, os monólogos de Irene Ravache fazem uma costura que trazem ao presente as cicatrizes do passado. Dialogando ora com o espectador, ora com o torturador, ora com o homem desejado, suas intervenções voltam-se para a câmera, seus olhos e suas ações encaram e provocam às/aos que assistem. Numa ocasião em que interpreta ter acabado de ser despedida, refere-se ao ex-chefe como um novo tipo de carrasco, e relaciona a violência que sofrera na tortura a essa nova situação: "Não adianta dizer que não tem nada a ver, porque tem”, insiste. Em seguida, percebendo que talvez isso seja um devaneio, afirma que está "amarrada, mais uma vez pendurada”. Quando finaliza essas palavras, a câmera faz 
um enquadramento que deixa, na mesma tela, a atriz ao lado de um enfeite de anjo. Sua presença em cena não é apenas a de um objeto de decoração: as asas revelam uma vontade grande de voar, de libertar-se. Os fios que o prendem, os limites em mover-se. Atada aos traumas do passado, a liberdade da personagem fica também tolhida no presente.

Os depoimentos do filme, como os citados nos parágrafos acima, abarcam outra questão importante ao trazer em cena um assunto cujo debate apresenta divergências entre suas/seus estudiosas(os): a especificidade de gênero na prática da tortura. O sistema repressivo brasileiro torturou homens e mulheres, e muitos casos podem ser lidos até mesmo em documentos produzidos pelas próprias autoridades do regime militar - como mostra o projeto Brasil: Nunca Mais. ${ }^{11}$ Para a psicanalista Maria Rita Kehl, a questão de gênero e suas relações não estão presentes na prática da tortura:

É claro que o torturador que goza com o corpo de uma torturada mulher goza de um jeito diferente daquele que goza com o corpo de um torturado homem, mas também goza. E aí não é a especificidade dos corpos, ou seja, todo corpo é passível de ser submetido, todo corpo é passível de ser apassivado, todo corpo é passível de ser estuprado. $\mathrm{O}$ fato de que as mulheres têm uma vagina não muda em nada, porque todo homem pode ser estuprado. [...] Não vejo uma especificidade sexual nesta experiência. ${ }^{12}$

11 Ver: Arquidiocese de São Paulo. Brasil: Nunca Mais. São Paulo: Vozes, 1985. Os arquivos completos desse projeto podem ser encontrados no Arquivo Edgard Leuenroth, do Instituto de Filosofia e Ciências Humanas da Universidade Estadual de Campinas (Unicamp). Mais informações sobre esse arquivo estão na nota 1 deste livro.

12 Fala retirada de sua participação no seminário A Revolução Possível: uma homenagem às vítimas da ditadura militar, realizado em 1996 no Instituto de Filosofia e Ciências Humanas da Unicamp. Na mesa-redonda intitulada A participação das mulheres na resistência à ditadura, além de Maria Rita Kehl, também participaram Criméia de Almeida, Rose Nogueira e Eleonora Menicucci. As fitas com os depoimentos realizados no seminário estão disponíveis na Biblioteca Prof. Dr. Octávio Ianni, do instituto citado. 
Contudo, o "jeito diferente" de o torturador gozar-e, nesse sentido, o jeito diferente de torturar, o jeito diferente de estuprar - está pautado nos significados sociais atribuídos aos corpos: dominar um corpo masculino e 'feminizá-lo' durante a tortura implica 'diminuí-lo', 'torná-lo inferior'. Os estudos que consideram a especificidade de gênero não estão baseados em concepções da natureza e da biologia, mas nos corpos femininos (e, por relação, nos masculinos) em suas dimensões política e cultural, ou seja, dos corpos tratados a partir da concepção do que é ser mulher e ser homem na sociedade. E no período retratado pelos depoimentos, a militância feminina em organizações revolucionárias era vista como uma dupla transgressão: a) assim como os homens, essas mulheres eram consideradas "fora da lei" por realizar operações armadas; b) a participação feminina na política era um desafio às convenções de gênero da época, marcada pelo conservadorismo moral que relegava as mulheres ao espaço privado em funções de mãe, esposa e dona de casa.

Elizabeth Jelin (2001, p.128-137) acrescenta que as informações existentes sobre a tortura indicam que o corpo feminino sempre foi um objeto especial para os torturadores; e as sevícias pelas quais as mulheres passavam incluíam sempre alta dose de violência sexual: "Los cuerpos de las mujeres - sus vaginas, sus úteros, sus senos -, ligados a la identidad femenina como objeto sexual, como esposas y como madres, eran claros objetos de tortura sexual". No caso dos homens, a questão de gênero está da mesma forma presente:

Para los hombres, la tortura y la prisión implicaban un acto de feminización de la víctima masculina, transformándola en un ser pasivo, impotente y dependiente (incluyendo, a veces, violencia sexual). Era una manera de convertir a los hombres en seres inferiores y, en ese acto, establecer la virilidad militar. Los hombres tenían que vivir como mujeres, tomando conciencia de sus necesidades corporales. (idem, ibidem)

Além disso, não se pode deixar de considerar que a repressão foi executada por instituições masculinas e patriarcais. As forças armadas e policiais agiam também com a intenção de restaurar a ordem 
"natural" de gênero, ou seja: viam-se com o dever de recordar permanentemente as mulheres sobre seus lugares na sociedade - estruturada pelo gênero. Buscava-se, com isso, a reafirmação de certas convenções de feminilidade que são, de certo modo, ambivalentes: recordar seus "lugares" significava enfatizar que deveriam cuidar dos filhos e do marido, e não colocar as mãos em armas. Como essas mulheres subvertiam tais condições, os agentes repressivos as tachavam de "putas".

A tortura às mulheres englobava, portanto, a questão política repressiva da ditadura e a questão da dominação masculina - convém ressaltar que apenas os homens torturavam. $\mathrm{O}$ fato de terem sido martirizadas enquanto mulheres perturba, em maior ou menor grau, a própria sexualidade. Lidar com tal situação implica diferenças para cada mulher, o que pode ser verificado no filme. Nos depoimentos das ex-presas, o tema da sexualidade gira em torno da maternidade; já na interpretação de Irene Ravache, ganha destaque a questão da busca do prazer sexual.

\section{A maternidade explica ou encerra tudo?}

Maria do Carmo inicia declarando a respeito de sua militância política. Fala do ponto com o companheiro, e do pacto que fizera com seu marido: se em algum momento fossem surpreendidos pela polícia, um deveria atirar no outro e se matar em seguida. Enquanto fala, algumas fotos do período de resistência aparecem na tela. E, numa referência à psicanálise - que se repete pelo filme e está na própria estrutura do documentário, desde o epílogo até o fato de ser Irene Ravache o alter ego de Lúcia Murat -, diz ter sido sua "parte saudável" que a fez não cumprir tal pacto: Maria do Carmo revela que seu marido se matou, mas ela decidiu atirar nos policiais. Antes de compreender sua escolha pela vida, sentia-se culpada por não ter morrido.

Essa mesma culpa está presente na fala de Rosalina Santa Cruz, quando questiona o desaparecimento de seu irmão, Fernando. "Por 
que eu sobrevivi e ele não?”. Ela enfatiza a dificuldade em relacionar-se com o prazer, já que era preciso conviver com a dor.

Culpa por ter sobrevivido enquanto outros morreram; culpa por ter sobrevivido e sentir-se responsável pelo cárcere e pela morte de outras(os) companheiras(os) ao não ter suportado todas as sevícias aos quais corpo e mente foram submetidos na tortura. Em outro depoimento emocionante, Pupi revela que "falar o que não quer falar; abrir, entregar [na tortura]. Entregar os companheiros tira um pedaço da alma”. O assunto altamente sensível deixa clara a dificuldade em lidar com essa questão; seu rosto demonstra toda dor que sente ao tocar nesse assunto. Como suportar esse fardo?

Tentemos unir os fragmentos do filme e voltemos à Maria do Carmo. Mais fotos suas são mostradas, enquanto a ex-guerrilheira narra sobre sua gravidez, que considera uma "descoberta tão bonita", pois era "produção de vida”. E, nesse caminho, conclui: "A melhor coisa no mundo é ser mulher. [Com a gravidez], descobri que ser mulher era o maior barato!". Corta. Na próxima cena, Maria do Carmo está na cozinha, cortando legumes para, em seguida, observar, pela janela, seus filhos brincando no parque infantil do condomínio. Ao mesmo tempo em que evidencia a dupla jornada de trabalho feminino, pois já foi revelado que a depoente tem uma profissão, essa montagem não deixa de conter certa ironia ao destacar as tarefas domésticas e o cuidar das crianças logo após a exaltação do quanto é bom ser mulher. Tal situação se insere numa preocupação em recuperar a história da militância e na dificuldade em restaurar esse passado no presente. Com voz-over, a narradora diz:

A história de Maria hoje, educadora casada, dois filhos, parece não ter muito a ver com esse passado [de militância e resistência à ditadura]. Como integrar essa dona de casa com a história épica da ex-estudante que organizava camponeses?.

O incômodo presente no questionamento sobre o passado e o presente dessas mulheres, ou sobre as façanhas da militância em comparação ao dia a dia, é transferido ao/à espectador(a) pela monta- 
gem do filme. A cineasta repassa essa inquietação quando intercala as atividades domésticas às imagens de arquivos do período da militância, ou quando sobrepõe a narração em voz-over que compara aquele período e as atividades atuais. Repete essa fórmula, mesmo que de maneira não evidente, nas outras entrevistas nos momentos em que o cotidiano dessas mulheres é filmado.

Observemos também o caso de Criméia como modelo: ela é filmada sentada em casa, fazendo tricô, enquanto a narradora diz que ela "vive em um apartamento pequeno" e a câmera mostra esse espaço. Em seguida, seu depoimento em close é intercalado com fotos de arquivo sobre a Guerrilha do Araguaia, que também ficam em primeiro plano. Assim, a cineasta mostra a dificuldade das tramas da memória, quando os fios do passado parecem ser de um tipo muito diferente dos fios que compõem o presente, embora estes sejam, ao mesmo tempo, obras daqueles.

$\mathrm{Na}$ árdua tarefa de entrelaçar esses fios, Que bom te ver viva mostra as tensões que permeiam essa atividade - e a voz dos filhos das militantes ou a voz da narradora apresentam alguns dos paradoxos mais exemplares. Em certo momento, a partir da fala de uma das depoentes, recebemos em voz-over a informação de que "sua história [da militante] não faz parte do mundo de seus filhos" - o que parece ser um não entendimento do legado destrutivo da ditadura, já que o "não fazer parte" é consequência das políticas econômicas e sociais de conciliação entre a sociedade e o passado recente. Porém, em outro momento, na voz do próprio filho de uma militante, escutamos que ele pensa em "tentar terminar o que [o pai, que militava com a mãe] começou”. Uma relação forte entre passado e presente, do passado no presente. Eé a partir desses laços envolvendo militância e maternidade que encontramos mais vestígios sobre uma pergunta que permanece aberta: como arcar com o peso da culpa?

Vejamos mais algumas cenas. Regina Toscano diz que foi presa grávida, e que perdeu seu filho nas sessões de tortura. Nessa situação, transformou a dor em esperança: a vontade de ser mãe foi responsável por permanecer viva; a "certeza de ter outro filho representava a vida". Nesse momento, o filme corta o depoimento para 
acompanhar a chegada de Regina ao quarto onde estão seus filhos. Deita-se em uma cama de casal com todos, procurando beijá-los e abraçá-los. Corta. A câmera muda o enquadramento para que possamos ver todos numa mesma moldura, quase uma foto de família contemporânea.

A depoente Pupi descreve da seguinte maneira sua gravidez: "Quando eu fiquei grávida, eu tava até fazendo terapia, e aí o terapeuta falou: vai embora para casa, vai ter seu filho. É uma vida nova que surge e uma esperança grande que vem junto. E aí você se desloca do social mais para o individual". Novamente vemos uma longa cena da mãe com as crianças. Na sala, Pupi está sentada no sofá, observando seus filhos que, com fantasias de carnaval, brincam com uma espécie de véu - utilizado pelo menino para laçar a menina, o que não deixa de demonstrar a especificidade de gênero na educação das crianças. Em um dos poucos momentos no qual o filme abre espaço para a trilha sonora, uma música infantil natalina compõea cena.

Criméia também acrescenta que a gravidez foi algo muito marcante: "Eles tentam acabar comigo, e nasce outro, aqui mesmo". Para a narradora, "o filho se libertando do útero é sinal de liberdade". Esta é a única a dizer que, embora seja muito gostoso ficar grávida, vê uma segunda gravidez como algo "pavoroso".

Em outra situação, vemos um filme dentro do filme na cena em que Jessie Jane e seu companheiro estão assistindo a um vídeo que repassa no retroprojetor do casal. Momentos de sua saída da prisão e do reencontro com sua filha ainda pequena são destacados, seguidos de fotos dela com a criança. Novamente uma música, dessa vez, tranquila, completa essa sequência que, somada às outras três citadas acima, demonstram a importância da maternidade na vida dessas mulheres.

Outros depoimentos do filme igualmente abordam a maternidade de forma intensa. Nos monólogos interpretados por Irene Ravache não há referência sobre essa questão, mas, como já foi observado, a personagem mescla-se à própria cineasta. É dela a voz-over que ouvimos, comentando cenas ou acrescentando informações. E, nesse sentido, a presença da maternidade exacerba-se na 
própria forma do filme: tanto pela seleção dos trechos de depoimentos que ouvimos a cada face em close, como nos demais elementos de construção fílmica - nos comentários em voz-over, na forma pela qual o documentário mostra as crianças, na opção por colocar o número de filhos na legenda que apresenta cada entrevistada.

Mas o que significaria ou revelaria essa insistência na questão da maternidade presente no filme? Uma convenção de feminilidade, já tão debatida pelas diferentes correntes do feminismo, não pode ser compreendida sem que se leve em conta suas tensões e ambiguidades. Retomando a forma como Joan Scott explicita os laços entre gênero e poder, Lucila Scavone (2004, p.41) exemplifica esse assunto:

Ela [a maternidade] pode ser abordada não apenas como símbolo de um ideal de realização feminina, mas também como símbolo da opressão das mulheres, ou símbolo do poder das mulheres, e assim por adiante, evidenciando as numerosas possibilidades de interpretação de um mesmo símbolo.

Ou seja, compreender a questão da maternidade requer reconhecer suas ambiguidades. Como estamos tratando de cinema, a observação de Teresa de Lauretis (2003, p.6) parece-me completar essas ponderações: "as imagens são (potencialmente) férteis em contradições, tanto no processo subjetivo quanto no processo social”. A autora acrescenta que

[...] no conceito de feminilidade como uma condição privilegiada, uma proximidade à natureza, ao corpo, ao lado maternal ou ao inconsciente. No entanto, somos alertados, tal feminilidade é puramente uma representação, um posicionamento dentro do modelo fálico de desejo e significação; não se trata de uma qualidade propriamente da mulher. (De Lauretis, 1993, p.130).

Nesse sentido, a experiência da maternidade não deve ser entendida em termos de evidência, mas, como propõe Joan Scott (1999), 
ela deve ser historicizada. Colocar a visão do sujeito como suporte da evidência não questiona a forma pela qual essa visão é/foi estruturada - fato que pode reproduzir sistemas ideológicos estabelecidos em vez de contestá-los. Para impedir essa situação, é necessário historicizar a experiência, o que requer um estudo dos processos histórico-sociais que, de forma dialética, produzem e são produzidos pela experiência. Trata-se de explorar como se estabelecem as relações sociais, como e de que forma interferem no momento e no modo em que os sujeitos relatam suas vivências:

A experiência, de acordo com essa definição, torna-se não a origem de nossa explicação, não a evidência autorizada (porque vista ou sentida) que fundamenta o conhecimento, mas sim aquilo que buscamos explicar, aquilo sobre o qual se produz conhecimento. Pensar a experiência dessa forma é historicizá-la [...]. (Scott, 1990, p.27)

A visão conservadora, que idealizava e naturalizava a maternidade, é o ponto de partida das diferentes propostas feministas sobre o tema, cuja discussão teve destaque nos décadas de 70 e 80. Duas principais correntes no feminismo preocupavam-se com esse debate.

A primeira posição, que negava qualquer tipo de imanência no feminino, considerava a maternidade como construção social e como o principal eixo da opressão das mulheres. A segunda posição afirmava a materialidade do ser mulher, dando relevância à dimensão biopsicológica e, inspirada na psicanálise, acentuava a importância dos ciclos de desenvolvimento do corpo feminino. Ambas as correntes, quando radicalizadas, apresentavam posições estanques em suas propostas: a primeira, por desconsiderar a vivência feminina do seu corpo; a segunda, por universalizar a família edípica.

Numa crítica aos escritos feministas desse período que apresentavam a maternidade como "fardo biológico, algo que tem de ser superado”, Maria Lygia Quartim de Moraes (1996, p.91) declara que a experiência da maternidade é um momento constituinte do ser mulher: 
Ter ou não sido mãe (inclusive ter passado pelos momentos naturais, vale dizer, ser mãe biológica) é algo que distingue radicalmente as possibilidades de vivência das mulheres com relação aos homens (e as feministas estão certas por criticar Freud e sua cegueira com respeito à inveja masculina), e também diferencia as mulheres entre si.

Essas diferenças não estão pautadas apenas entre mulheres que optam por filhos e aquelas que optam por não tê-los, mas também na maneira pela qual cada mulher vivencia a maternidade. Nesse sentido, o estudo da forma pela qual o filme Que bom te ver viva trabalha tal questão recebe novos instrumentos de análise. Em trabalho realizado com mulheres de uma comunidade de São Luiz do Maranhão, Lucila Scavone (2004, p.153) faz uma importante observação:

[...] deve-se considerar, igualmente, o significado e o desejo da maternidade no universo estudado. Isto porque a vontade de ter filhos(as) aparece como um fato inquestionável e de bastante força na vida destas mulheres, apesar de todas as dificuldades materiais que enfrentam no cotidiano. Este desejo é justificado por fatores circunscritos ao plano afetivo e psicológico, os quais representam elementos importantes à realização da maternidade.

Apesar de se referir a um contexto diferente, essa citação possibilita compreender a situação das depoentes do documentário de Lúcia Murat - e também de outras mulheres que atuaram na resistência à ditadura militar. A partir dessas discussões, observo que o filme Que bom te ver viva oferece um tipo de "armadilha da maternidade”. Utilizo essa expressão inspirada em Simone de Beauvoir, mas numa interpretação diferente à abordada pela pensadora francesa. Em entrevista concedida aos 77 anos, a pensadora francesa fazia a seguinte afirmação:

Eu não recuso a maternidade. Acho apenas queé uma armadilha. $\mathrm{O}$ que se deve condenar não são as mães, mas a ideologia que incita as mulheres a serem mães e as condições em que devem sê-lo. Junta-se a 
isso uma mistificação perigosa da relação mãe-filho. Mesmo que uma mulher tenha vontade de ter filhos, deve refletir muito porque a maternidade, atualmente, é uma verdadeira escravidão. ${ }^{13}$

Recupero o termo "armadilha" para pensá-lo em sentido de possibilidade: pode-se ou não cair na emboscada. A armadilha da maternidade que vejo no documentário de Lúcia Murat está ligada à forma pela qual o filme atualiza tal convenção de feminilidade. Por um lado, a valorização da maternidade é exposta nas longas cenas com as crianças, nos depoimentos e nos elementos fílmicos, como exemplificados nos parágrafos acima. Tal fato sugere uma aproximação àquela corrente do pensamento feminista que afirma a imanência do feminino, e que considera a maternidade um poder insubstituível - poder este possuído pelas mulheres e invejado pelos homens.

Dá o que pensar essa observação, já que se encontra no limiar da ideologia dominante e, muitas vezes, é por ela absorvida e dissimulada numa outra concepção, que valoriza e santifica o ser mãe e o cuidar integral da mulher à criança e ao lar. Nas palavras de Maria Lygia Quartim de Moraes (1996, p.93), trata-se de uma noção que, além disso,

[...] é antisséptica, romântica, deixando de lado o choro às noites, as fraldas sujas etc. O processo de produção do bebê não entra em questão. É uma concepção de maternidade que esvazia a vivência concreta de sua realidade material e, mais ainda, de sua realidade afetiva. Porque há pessoas neuróticas, ignorantes, violentas e incapazes de amar. Porque a maternidade envolve ambivalentes sentimentos de amor e ódio, e é também o lugar de muitas fantasias.

Por essa esteira, cabe questionar o caráter ideológico da maternidade em nossa sociedade: ao mesmo tempo em que é valorizada, não

13 Beauvoir, Simone de. Não se nasce mulher; torna-se mulher. Revista Cláudia, 1985. Apud Moraes, 1996, p.29. 
se encontram condições materiais para sua realização. A consequência dessa situação é que "a maternidade como prazer torna-se um privilégio de classe” (Scavone, 2004, p.156).

Retomando a discussão a partir do filme, a narradora propõe uma tentativa de contraponto à experiência da maternidade em duas situações. A primeira está relacionada ao fato de que a personagem de Irene Ravache não tem filhas(os). A segunda tentativa se estabelece quando questiona as falas da mãe e da amiga de uma das depoentes. Num determinado momento, a mãe de Maria do Carmo que afirma que sua filha "está feliz, teve dois filhos"; e uma amiga também acredita na sua superação, já que a ex-guerrilheira "teve dois filhos". Em seguida, com o recurso da voz-over, a narradora parece contestar essas afirmações: "Na maternidade, Maria diz ter resgatado a possibilidade de vida. Mas isto explica ou encerra tudo?”. Trata-se de um ensaio de oposição às afirmações das duas, que pode ser entendido como uma vontade de explicar que a situação é mais complexa do que as falas de ambas.

Daria uma discussão interessante nas telas se o filme se arriscasse na empreitada de questionar de forma mais radical tais posições. Contudo, esse embate fica enevoado quando, logo após a pergunta acima, a mesma voz-over responde: "Mas, quando se tornou mãe, [Maria do Carmo] também entendeu isso".

O filme caminha, portanto, para uma outra proposta ao trazer em debate o tema da maternidade. Como já observado, as memórias pessoais sobre a tortura estão fortemente marcadas pelo corpo. Como as experiências se refletem nas diferentes qualidades de memória ou seja, a experiência tem gênero -, a presença da maternidade nos depoimentos femininos passa a ser compreendida de outra forma. Vejamos isso melhor.

Eleonora Menicucci de Oliveira (1996), em texto publicado após participar de um seminário na Unicamp, ${ }^{14}$ afirma ter havido "um sentimento de maternidade que a tortura fez vibrar em meu

14 As informações sobre esse evento estão na nota 12 (p.82). 
próprio sangue, e foi através desse sentimento que busquei a força da resistência”. Em sua opinião, dois aspectos se destacam em relação às torturas sofridas no período da ditadura militar. Primeiro, que o corpo feminino foi "utilizado e vilipendiado" pelos torturadores a partir da concepção do que é ser mulher em nossa sociedade. Segundo, e parece-me que se trata de consequência do primeiro, que a relação mãe/filhas(os) foi usada como estratégia pelos agentes da repressão - sua filha, então com um ano e dez meses, foi colocada na mesma sala para assistir à tortura que a mãe, amarrada na cadeira-do-dragão, estava sofrendo. A autora completa o que ocorreu:

O meu marido estava sendo torturado em outras salas, mas com ele não se repetiu esta cena, embora os torturadores tenham dito a ele o que sucedia ao lado. Dois corpos torturados e submetidos como objetos nas mãos dos torturadores, anulados enquanto sujeitos, mas explicitamente diferenciados sexualmente. Cada história de vida é uma história de um corpo, e cada corpo tem um sexo que tem um valor histórico, social e culturalmente. (idem, ibidem)

Além de reafirmar a especificidade de gênero na tortura, as palavras da autora demonstram a maternidade enquanto forma de resistência. ${ }^{15}$ Pensando nos depoimentos do filme, percebemos que as entrevistadas deixam claro que se trata de uma maternidade livremente escolhida, cuja opção se deu, na maioria dos casos, num contexto em que boa parte das depoentes passou a refletir suas vivências, principalmente por intermédio da terapia psicanalítica -e, em vários casos, a partir também do feminismo. Como acrescenta a autora, as militantes de partidos clandestinos de esquerda incorpora-

15 A consideração da maternidade como forma de resistência pode também lançar luzes sobre o caso argentino, onde filhos e filhas recém-nascidos(as) de militantes contrárias à ditadura daquele país eram violentamente retirados de suas mães para serem adotados por militares. Agradeço ao professor doutor Marcelo Ridenti por esta observação. 
vam, muitas vezes, "o modelo masculino da coragem e do poder viril" para serem aceitas nessas organizações que, de certa forma, transformava as pessoas em "militantes impessoais". Ao mesmo tempo em que contribuíram para conquistar novos espaços e trilhar outros caminhos, rompendo com uma série de preconceitos,

[as mulheres daquela geração] também atuaram com cumplicidade nas relações de poder entre os gêneros no interior dos movimentos de esquerda, mesmo porque, para atenderem as expectativas de 'revolucionárias', ficavam em sua maioria presas ao modelo do macho, do forte, do corajoso e do frio. Nosso corpo foi colocado como propriedade da revolução social, para usufruto da organização a qual pertencíamos. Microcosmo de poder dentro das organizações. E poderia ter sido diferente? Penso que não, pelo fato de sermos muito jovens e termos pressa. (idem, ibidem)

Assim, o momento em que refletem suas vivências é também o momento em que procuravam afirmar-se subjetivamente como... mulheres! O que deve ser levado em conta, em primeiro lugar, é relembrar que as entrevistadas sentiram também em seu corpo as sevícias da tortura. Não é por acaso que o usem como instrumento de luta, de reafirmação.

Os estudos de gênero somados aos estudos queer mostram que, por um lado, não devem ser negados a plasticidade da sexualidade humana e os 'deslocamentos' do feminino e do masculino, provocados pelas conquistas que transformam a situação da mulher. Por outro lado, afirmar tal plasticidade do corpo biológico não significa negá-lo, superdimensionando as forças do cultural e do simbólico: "as fórmulas genéricas (como gênero) obrigam a uma reflexão sobre a relação entre corpo e psique” (Moraes, 2007, p.128), ou seja, trata-se de compreender a importância da experiência desse corpo para a subjetividade. De acordo com Mariza Correa (2001), deve-se levar em conta a desnaturalização e a dessencialização das definições e classificações humanas, como o sexo e a raça. Contudo, como ressalta a autora, não se deve esquecer que é no corpo que essas marcas classificatórias são impressas. 
A maternidade é, então, entendida como uma prática social e subjetiva feminina, aparecendo nos depoimentos de Que bom te ver viva como fonte de vida, de renovação de forças para seguir em frente: é a marca da diferença entre a vida e a morte. O sentimento de culpa reiterado pelas militantes é por elas deslocado quando encontram um novo sentido para viver. A armadilha da maternidade pode ser desarmada quando se percorre o labirinto da memória construído pelo filme, cuja saída no presente é uma resposta às dores do passado. Da culpa pela sobrevivência à esperança via maternidade: é assim que o fardo que cada uma dessas mulheres carrega parece diminuir, ao dar a vida e cuidar da vida. ${ }^{16}$

\section{Eu gosto de trepar. Por que eu não tenho o direito de gostar?}

Nos depoimentos das entrevistadas, sobressaem suas experiências em relação à tortura e à maternidade. Já nos monólogos de Irene Ravache, vemos uma maneira diferente de tratar as questões da tortura e da sexualidade, pois esta aparece deslocada da reprodução. Os conflitos vividos por sua personagem demonstram intensidade quando o trauma irrompe em ocasiões diversas do cotidiano, fazendo com que ela se perca na confusão de seus pensamentos.

Em determinado momento, a câmera, em plano fixo, enquadra do rosto à cintura de Irene Ravache. Com um vestido preto, olhando-se no espelho, suas costas estão nuas. Uma cena sensual, que parece destoar das demais e, em certo sentido, provocar a própria narrativa do filme: é o momento em que ela fala abertamente sobre o sexo e prazer, e também sobre o fato de sentir uma cobrança social para que não tenha esses desejos. Encostando-se no espelho, afirma:

Como eu gosto de trepar com você! [ [...] Eu finjo que não sofri tortura sexual, você finge que não sabe de nada. Eu finjo, tu finges, e nós

16 Inspiro-me aqui no título do livro de Lucila Scavone (2004). 
fingimos... O resto é passado, o resto é violência, o resto acabou. Ah, meu amor, que mentira! Eu odeio quando vocês dizem que nunca mais trepariam. Eu gosto de trepar. Por que eu não tenho o direito de gostar?

Novamente, uma divagação em relação ao tempo, desta vez para unir o passado de tortura ao presente que busca prazer. A tensão entre tentar deixar a violência no passado e a insistência dessa mesma violência em aparecer no presente; a vontade de "fingir", e o não acreditar no próprio fingimento; a busca por uma relação sexual sem culpa, mas um sentimento de que o prazer sexual é coibido por "vocês", pela sociedade. A cineasta revela, nessa sequência, uma dupla cobrança que sente por parte da sociedade: o esquecimento do passado para continuar a viver; a lembrança desse passado para que continue a sofrer. Um questionamento latente da falta de entendimento que a sociedade tem do período ditatorial, uma crítica que passa pelo corpo, pela sexualidade, pelo cotidiano.

Essa fala demonstra a complexidade de uma questão que extrapola o âmbito individual. 'Sentir prazer', 'gostar de trepar', 'fingir': mais do que um problema específico das mulheres que sofreram fortes sevícias por serem militantes, trata-se de um problema geral relacionado a todas as mulheres que sofrem sevícias por serem mulheres. Nesse sentido, aproximam-se os planos pessoal e social, sexual e político, afetivo e histórico. Por essas características, o filme mostra a tensão e a luta que envolvem a afirmação "nosso corpo nos pertence", e revela novamente vinculação com temas feministas, cujo movimento engendrou tal enunciado nas suas ações políticas realizadas no Brasil em fins da década de 70. Como informa Eleonora Menicucci de Oliveira (1996), esse feminismo baseava-se no resgate do direito ao corpo e ao conhecimento sobre ele, para que as mulheres tivessem em mãos o destino e o caminho de suas vidas.

Como observado no primeiro capítulo deste livro, o movimento feminista brasileiro passa a tratar temas fundamentais na década de 80 , como os relativos ao corpo, ao desejo e ao aborto, dando visibilidade a essas questões tabus. Desenha-se um perfil mais voltado para 
as áreas da saúde e da violência, ${ }^{17}$ as quais estão intrincadas à opressão sexual que se dá sobre o corpo e a sexualidade. E são esses os temas de destaque em Que bom te ver viva: a violência (de gênero) da tortura; e a saúde (psicológica e do corpo), dividida nas falas sobre maternidade e prazer sexual.

Um comentário se faz necessário, dada a característica ambígua da personagem de Irene Ravache. Se, por um lado, ela costura os depoimentos e pode ser vista em uma posição que complementa as demais militantes, não se pode negar que, por não ser mãe como as demais (exceto a mística), também exerce o papel de fazer um contraponto às depoentes. Pensando neste segundo ponto, o filme traz em cena o dualismo entre vida reprodutiva (nas mães, que não falam sobre sexo e prazer) e vida sexual com prazer (a busca da personagem narradora, que não tem filhos). Com isso, deixa-se de aproveitar uma valiosa oportunidade para debater com mais rigor uma importante convenção de feminilidade, a qual evita ver a mulher enquanto mãe e sexuada ao mesmo tempo.

Ao redor dos temas da tortura e da sexualidade, observam-se os sentimentos e as vidas prejudicadas. O legado destrutivo da ditadura persiste nos corpos e nas sensações dessas mulheres, como também persiste em suas relações sociais, marcadas pela dificuldade em conversar sobre o ocorrido. Estrela afirma que, de uma forma geral, na sociedade "[a tortura] é um assunto que incomoda tanto que é melhor que se esqueça”. A experiência emocional interna em relação à tortura, diz a depoente, é algo que ninguém quer ouvir. Essa situação demonstra a falta de testemunha - aqui entendida no sentido amplo do termo, como proposto por Jeanne Marie Gagnebin

17 Vale ressaltar a mobilização de campanhas nacionais na denúncia de morte de mulheres por "crimes de honra", como o conhecido assassinato de Ângela Diniz por Doca Street, ocorrido em dezembro de 1976. Tratando-se de um crime que envolvia a elite carioca, foi amplamente noticiado pela imprensa. Repudiando o primeiro julgamento do caso - que o absolveu sob o argumento de "defesa da honra" -, o movimento feminista passou a utilizar com força o slogan "Quem ama, não mata!”. Em segundo julgamento, o assassino foi condenado a cumprir pena por homicídio. 
(2001) e explicado no primeiro capítulo deste livro. Ou seja, é necessário que haja pessoas dispostas a ouvir a narração do outro, mas a carência de ouvintes é mais um obstáculo para a elaboração do passado, cujas cicatrizes permanecem pendentes.

Em voz-over, a narradora informa que Estrela, na tortura, foi obrigada a ficar nua junto aos demais presos e presas, que caminhavam numa espécie de cortejo para exaltação divina. A opção da ex- militante em estudar filosofia após a saída do cárcere foi a forma encontrada na tentativa de entender "a loucura latente daquela procissão”. Buscam-se diferentes alternativas para suportar o trauma. A filosofia, para Estrela; a vida religiosa, para a depoente que preferiu não se identificar. No caso da cineasta Lúcia Murat, a escolha foi fazer o filme Que bom te ver viva:

O filme parte das minhas crises. Mistura a realidade com o delírio. Foi minha forma de lutar contra minha angústia, de surpreender e de compreender essa história, de lutar contra a loucura. Porque o caminho para a loucura entre as vítimas da tortura passa por essa não admissão de entrar na discussão do que aconteceu.

A procura pela compreensão de algo que, quando não elaborado, irrompe em diversos momentos da vida daqueles(as) que o sofreram: a personagem de Irene Ravache revela, em seus devaneios, a dificuldade em manter-se sã, e o quanto suas questões cotidianas estão intrincadas à dominação que estrutura as relações sociais.

Os acontecimentos reais relatados nos depoimentos são amplificados pelos acontecimentos imaginários dos monólogos. Essa combinação livre do real e do imaginário desenvolve a capacidade de intercalar temas que trazem a participação política no espaço público com questões cotidianas, habitualmente associadas à vida privada. Declarações afetivas se impõem sobre o discurso fechado da razão do Estado e da Política. Isso não significa que o mundo privado e o mundo público encontrem-se indiferenciados, mas os colocam em relação de outro modo, despojados dos privilégios hierárquicos com os quais são habitualmente apresentados. 
Nesse sentido, pode-se observar que, pela sua capacidade de politizar as relações privadas, o filme de Lúcia Murat trabalha com uma importante característica do pensamento feminista. O pessoal é político está na raiz das críticas do feminismo à convencional dicotomia liberal público x privado. Como afirma Susan Okin (2008),

[...] as teóricas feministas, focando o gênero e argumentando que poder e práticas políticas e econômicas são estreitamente relacionados às estruturas e práticas da esfera doméstica, expuseram o quanto a dicotomia entre público e doméstico, também reificada e exagerada pela teoria liberal, serve igualmente a funções ideológicas.

Tal como a proposta feminista, Que bom te ver viva atenta-se à política da esfera pessoal da sexualidade e da família, convencionalmente considerada como 'não política'. A atual organização da sociedade contemporânea mantém-se profundamente afetada pela percepção de que duas esferas - separadas e distintas - dividem a vida social. Esse pensamento reifica e legitima a estrutura de gênero na sociedade, pois considera 'natural' a ligação da mulher na criação dos filhos e na domesticidade, situando essas questões fora do escopo da crítica política.

Esse tipo de abordagem é desafiado por pesquisadoras feministas quando argumentam que a divisão sexual do trabalho e a prevalência da mulher na responsabilidade de criação dos filhos são socialmente construídos e, portanto, questões de relevância política. Isso não significa que a afirmação o pessoal é político seja interpretada como uma identificação simples e total entre as duas esferas. Para Susan Okin (op. cit.), trata-se de entender que

[...] o que acontece na vida pessoal, particularmente nas relações entre os sexos, não é imune em relação à dinâmica de poder, que tem tipicamente sido vista como a face distintiva do político. E nós também queremos dizer que nem o domínio da vida doméstica, pessoal, nem aquele da vida não doméstica, econômica e política, podem ser interpretados isolados um do outro. 
Essa bandeira feminista insiste sobre o caráter estrutural da dominação expresso nas relações da vida cotidiana. Quando essas relações são entendidas apenas como produto de situações pessoais e/ ou naturais, seu caráter sistemático de dominação fica obscurecido. O que o feminismo busca é mostrar os artifícios estruturais pelos quais poderosas instituições - como a família e a divisão sexuada do trabalho e do emprego - ocultam e asseguram a dominação.

O fato de Que bom te ver viva explorar as questões subjetivas, politizar as relações privadas, questionar a sexualidade e a violência contra as mulheres, demonstra que, tanto do ponto de vista do conteúdo quanto da forma, está em diálogo com as conquistas feministas. As condições objetivas e subjetivas para que temas como esses pudessem ser trabalhados devem muito ao feminismo e ao exercício de memória realizado por suas militantes, embora tal situação não deva ser entendida em termos de causa e consequência: o filme de Lúcia Murat não apenas é parte dessas condições, como também ajuda a produzi-las.

Contudo, algumas tensões permanecem: em seu labirinto da memória, vimos que o filme de Lúcia Murat soube articular o passado ao presente. Vimos também, no primeiro capítulo deste livro, que o trabalho de memória se completa quando o passadoé resgatado tendo-se em vista os desafios do presente e a perspectiva futura - apenas assim pode ser entendido enquanto transformação libertadora. É necessário, portanto, verificar de que modo o filme observa o tempo vindouro, e se há alternativas emancipatórias na memória que manifesta.

Antes de entrar nessa questão, faço uma breve incursão a outros filmes que expõem interpretações sobre a participação política na resistência à ditadura civil-militar. Penso que a comparação entre o documentário performático de Lúcia Murat com filmes que enfatizam outros momentos desta mesma resistência à ditadura, mas estruturados por uma narrativa ficcional baseada na ação, podem trazer elementos significativos para se pensar: a) nas relações de gênero trabalhadas pelos filmes e suas respectivas construções de feminino e masculino; b) os paradoxos e tensões presentes na reconstrução histórica, marcada pelos conflitos em torno da memória. 


\section{3 \\ OUTRAS VOZES NOS CONFLITOS DA MEMÓRIA}

A mistura de documentário e ficção em Que bom te ver viva enfatiza a complexidade emocional da experiência na perspectiva da própria cineasta. Composto pelo tom autobiográfico com ênfase nas características subjetivas da experiência e da memória, afasta-se do relato objetivo: a encenação do desejo; a raiva ao encarar a câmera como se esta fosse o torturador; a provocação quando, em outro momento, esta mesma câmera é encarada na qualidade de classe média; a densidade dos depoimentos. São particularidades que permitem aproximar o filme ao tipo qualificado por Bill Nichols (2005, p.171) como performático: ${ }^{1}$

Os documentários performáticos dirigem-se a nós de maneira emocional e significativa em vez de apontar para nós o mundo objetivo que temos em comum. Esses filmes nos envolvem menos com ordens ou imperativos retóricos do que com uma sensação relacionada com sua nítida sensibilidade. A sensibilidade do cineasta busca estimular a nos-

1 Bill Nichols (2005) afirma que os documentários do tipo performático são bastante comuns na cinematografia feminista norte-americana, bem como no cinema que trabalha com temas como a homossexualidade e a etnia. 
sa. Envolvemo-nos em sua representação do mundo histórico, mas fazemos isso de maneira indireta, por intermédio da carga afetiva aplicada ao filme e que o cineasta procura tornar nossa.

O filme de Lúcia Murat é produzido dentro de um movimento do cinema brasileiro com marcas específicas a partir do final da década de 70, e que permanece na década de 80. Como explica Ismail Xavier (2001), esse período é marcado por filmes cuja postura principal é a de abrir os olhos do observador, levantando a poeira dos arquivos para ver e ouvir os agentes históricos e as testemunhas do processo social. A combinação de fotografias, filmes de arquivo, entrevistas e comentários do narrador é característica de um cinema que, pelo trabalho de montagem, assumia interpretações de um passado recente. Em suas palavras,

A mulher, o negro, o índio, a comunidade religiosa, o burguês nacionalista sabotados. Na multiplicidade de problemas, a preocupação comum em afirmar valores, iluminar experiências históricas, dentro de um impulso de revisão do passado muito próprio dos anos 1970 e 1980. Resgate, memória, emergência de outras vozes ou reafirmação dos mesmos mitos são dados de um inventário que envolve a política of icial da preservação e o movimento das oposições no sentido de documentar e veicular a informação interditada. (idem, p.88)

Diversos filmes desse período e também de anos posteriores expõem suas visões a respeito da ditadura. Diferentes atores sociais, participantes ou não da resistência ao regime repressivo, manifestam suas interpretações sobre o passado recente em um campo marcado pelas memórias em conflito. Nas produções cinematográficas realizadas após a anistia, observa-se um tipo de cinema no qual, de acordo com Ismail Xavier (2001, p.102),

Podemos identificar algo como um naturalismo da abertura, cujas faces mais visíveis são, de um lado, o filme policial com temas ligados à repressão e, de outro, o movimento geral do 'sexo em cena', que manifesta num amplo espectro. [...] O policial-político se põe como espetá- 
culo para comunicar, convencional, bem dosado, sem enveredar pelo naturalismo grotesco, [...] e sem, por outro lado, alcançar o realismo de investigação psicológica, mais denso na reflexão.

Enquadram-se como policial-político o filme Pra frente, Brasil, de Roberto Farias (1982), e O bom burguês, de Oswaldo Caldeira (1983). Na retomada do cinema brasileiro, outros filmes que manifestam sua memória sobre a ditadura militar são estruturados de modo parecido, como Lamarca, de Sérgio Rezende (1994) e O que é isso, companheiro?, de Bruno Barreto (1997), para permanecermos na década de 90 .

Devo esclarecer que não é intenção deste livro fazer uma oposição rasa entre ficção e documentário, considerando este como "mais próximo ao real”. Tal questão já foi amplamente discutida, como pode ser verificado nos textos de Paulo Menezes (1993; 1994) sobre os limites do documentário, mesmo aquele que se pretende fiel aos acontecimentos. Amparo-me também nas palavras de Ismail Xavier (1977, p.10) quando afirma que "[...] o cinema como discurso composto de imagens e sons é, a rigor, sempre ficcional, em qualquer de suas modalidades".

O que se pretende - e espero já ter demonstrado parte disso no capítulo anterior - é observar as articulações que os filmes fazem com seu tempo histórico a partir da manifestação da memória sobre certos acontecimentos que, neste caso, referem-se à participação política feminina na resistência à ditadura militar. No estudo do documentário de Lúcia Murat, observou-se que, além de dar visibilidade às militantes, possui uma estrutura fílmica que permite questionar certos padrões de representação - o que não faz sem tensões e ambivalências. Cabe verificar, agora, de que modo filmes ficcionais estruturados a partir do emblema policial-político trabalham esse tema.

Ao estudar filmes que se identificam ao naturalismo da abertura, deve-se ter em mente que tais produções se apoiam em fórmulas tradicionais. Neles estão presentes a estrutura dramática, o imperativo da ação, a composição de heróis e vilões: "tudo trabalha para que se 
ponha em cena uma coleção de fatos articulados de modo simplificado, resultando uma verdade de aparência reduzida" (Xavier, 1993, p.103). Por esse motivo, no lugar de fazer uma análise completa ou minuciosa de diversas obras, optei por destacar algumas sequências do filme O que é isso, companheiro?, cujas cenas oferecem elementos significativos em relação à militância política. Trata-se de um filme polêmico, já com extensa fortuna crítica: artigos, ${ }^{2}$ livros, ${ }^{3}$ monografias, ${ }^{4}$ dissertações ${ }^{5}$ e teses. ${ }^{6}$ Portanto, minha intenção não é dissecar o filme, tampouco insistir em questões que já foram trabalhadas com propriedade em outros textos.

O que me proponho a fazer para colaborar nessa discussão já existente sobre o filme é estudá-lo sob um ponto de vista ainda não trabalhado: verificar de que modo a memória sobre o período da ditadura é manifestada, mas a partir das relações de gênero nele presentes - o que não impede que observações de caráter mais geral sejam feitas. Ao redor dos temas trabalhados a partir de $O$ que é isso, companheiro?, breves referências a outros filmes da estética policial-política são citadas. No final deste capítulo, retorno ao documentário de Lúcia Murat para problematizar, após examinado os demais filmes, os limites e possibilidades da manifestação da memória.

\section{À procura da beleza, que existe!}

O filme nos ambienta no tempo e no espaço desde o início, marcando o período e o local de onde parte a narrativa: suas primeiras

2 Com destaque para Xavier, 1997, p.141-153.

3 A polêmica ao redor do filme foi gigantesca, chegando-se a publicar um livro a partir de uma coletânea de artigos cujos temas eram exclusivamente $O$ que é isso, companheiro?. Trata-se de REIS, Daniel Aarão et.al. Versões e Ficções: o seqüestro da história. São Paulo: Perseu Abramo, 1997.

4 Ver: Cassal, 2001.

5 Ver: Magalhães, 2001. Ver também: Cunha, 2006.

6 Ver: Aguiar, 2008. 
cenas são uma colagem de diversas fotos em preto e branco, mostrando pessoas na praia, no campo de futebol, em diversas outras situações. Uma legenda informa "Rio de janeiro, início dos anos 60" e, na trilha sonora, a música (internacionalmente conhecida) Garota de Ipanema está em seus versos "ah, por que estou tão sozinho? / ah, por que tudo é tão triste?".

Antes de ouvirmos as próximas palavras da canção, a música é abafada pela expressão "o povo unido jamais será vencido", entoada por uma multidão de pessoas que aparece em outra foto. No mesmo momento, duas grandes legendas ocupam a tela, com fundo preto e letras brancas: a primeira informa que "em 1964 o governo democrático brasileiro é deposto por um golpe de estado militar"; a segunda acrescenta que "em dezembro de 1968, a junta militar que governa o Brasil decreta o Ato Institucional n ${ }^{\circ}$ ”. A multidão de pessoas protestando já não é apenas uma foto, mas uma imagem em movimento, e a câmera destaca em close o rosto de três estudantes, que são apresentados na próxima sequência do filme.

Ainda em preto e branco, as cenas mostram o confronto entre os manifestantes e a polícia, quando a tela mistura essas duas cores para informar num primeiro quadro que "Luiz Carlos Barreto apresenta", e, num segundo, expor o nome do filme em letras cinza: "O que é isso, companheiro?".

Assim é feita a apresentação do filme dirigido por Bruno Barreto, baseado no livro homônimo de Fernando Gabeira (lançado em 1979). Enquanto esteve exilado na Suécia, o ex-militante do MR- 8 redigiu um texto que procurava dar conta do período compreendido entre 1964 e 1973. Escrito em primeira pessoa, o livro abrange a tomada de decisão do autor em participar de grupos guerrilheiros, passando pela façanha mais conhecida realizada pelo grupo no qual militava - o sequestro do embaixador americano Charles Elbrick -, e chega até os primeiros momentos de seu exílio. Verdadeiro fenômeno editorial, o livro ficou meses a fio na lista dos mais vendidos e teve sucessivas reedições. Em 1980, foi traduzido na França, na Alemanha e nos Estados Unidos. 
Nesse mesmo ano, é contemplado com o Prêmio Jabuti de melhor livro na categoria Biografia e/ou Memórias. ${ }^{7}$

Com frases limpas e secas, os parágrafos demonstram emoções contidas ou atenuadas. Mas uma questão recebeu mais atenção de diferentes críticos do livro: a reavaliação que Fernando Gabeira faz da luta armada, quando parece deslocar suas reflexões posteriores para o período em que os eventos ocorreram. Como afirma Mário Augusto Medeiros da Silva (2006, p.67),

O narrador de O que é isso, companheiro? parece querer convencer o leitor de que sua consciência crítica já estava formada no período; de que, apesar de estar se engajando, sabe dos limites do seu próprio compromisso e dos de seus companheiros.

Alípio Freire (1997, p.156), ex-militante, faz observação semelhante, acentuando de forma crítica a maneira pela qual a esquerda é apresentada:

No livro, porém, o personagem central é ficcional: o Gabeira personagem é uma figura que nos anos 60 já disporia de formulações críticas que, de fato (historicamente), só viriam a ser elaboradas coletivamente anos depois, como resultado de experiências, reflexões e formulações dos quadros e organizações de esquerda (no Brasil e no exílio), esquerda que o autor tenta desacreditar e desqualificar ao longo do trabalho.

O livro, cujas características permitem enquadrá-lo enquanto literatura de testemunho, pode ser interpretado no campo de conflitos da memória dentro da própria esquerda. Tal como o texto, o filme de Bruno Barreto pode ser entendido como manifestação da memória, pois reconstrói, a partir de suas escolhas, um passado re-

7 O curioso é que em nenhuma edição ou comentário de época a titulação é mencionada, embora seja confirmada pela Câmara Brasileira do Livro (CBL) em sua lista oficial (Silva, 2006, p.157). Para um estudo competente do livro de Gabeira, que possui esta e outras informações de grande importância, ver: Silva, 2006. 
cente. Contudo, há uma grande diferença a ser levada em consideração. Como observou Eugênio Bucci (p.223), "rigorosamente, [o filme] O que é isso, companheiro? não nos pertence, não brota de um movimento que guarde com a esquerda alguma cumplicidade histórica”. Ao apresentar nas telas sua interpretação do sequestro do embaixador americano pelos grupos guerrilheiros MR-8 e ALN, o longa-metragem foi alvo de divergências de opiniões, recebendo críticas principalmente por parte das esquerdas.

Voltemos, portanto, ao filme. A partir do momento em que o título aparece na tela, todas as imagens passam a ser coloridas. A primeira é a de uma televisão mostrando a chegada do homem à Lua e, numa opção pelo didatismo, uma legenda informa a data: "20 de julho de 1969". Assistindo a esse programa estão os três estudantes que participavam da manifestação bicolor: Fernando, César e Artur. São apresentados como simpatizantes da esquerda, embora Artur seja irônico a maior parte do tempo, e compartilham algumas ideias anti-imperialistas. Mais do que nos localizar no tempo, a imagem do homem chegando à Lua é o pretexto para a frase dita por aquele que, veremos, é o protagonista dessa história, o personagem inspirado do próprio Fernando Gabeira - até o nome do autor é mantido. Referindo-se ao astronauta, diz a Artur:

Pelo menos ele teve a grande aventura da vida dele. Não é por isso que estamos no mundo? Bom, vamos deixar a Lua e voltar para a Terra. A situação está muito ruim, estamos completando seis meses de imprensa censurada, a direita está no poder e não dá sinal que vai sair.

Após essas palavras, Fernando diz ao amigo sobre sua decisão em participar da luta armada - mesma decisão que teve César. Por esse modo, sem considerar o fundo político-cultural da época, a esquerda armada é reavaliada como uma grande aventura! Mas, longe de ser uma experiência bem-sucedida tal qual a ida do homem à Lua, os únicos versos cantados no início do filme já parecem indicar que se trata de uma aventura solitária (ah, por que estou tão sozinho?) e infeliz (ah, por que tudo é tão triste?). 
Logo depois, Artur, que se recusa a participar da luta armada, dá a entender que é suicídio cair na clandestinidade e participar de um grupo guerrilheiro. Mais que isso, diz que os que optam por essa via o fazem para "aparecer". Mais alguns vestígios do modo pelo qual a memória da militância é reconstruída no filme: a decisão pela luta armada parece ser o resultado do inconformismo de rebeldes sem causa, de jovens que querem, apenas, fazer-se notar! Omite-se, tanto nos versos cantados como nas duas sequências acima descritas, a "beleza que existe" no significado profundo do gesto militante com seu desejo de transformação radical da sociedade, que já estava marcada pela concentração de poder e exclusão social, por relações mercantilizadas e consciências embrutecidas.

\section{Entre 'sargentinhas' e 'meninas inseguras'}

Fernando vai à luta armada. Com os olhos vendados, sai de seu apartamento e é encaminhado pelo militante Marcão até o aparelho. Lá, encontram mais três "recrutas", e os quatro iniciantes recebem novos nomes: Renée, Júlio, Osvaldo (César) e Paulo (Fernando). ${ }^{8}$ Marcão pede que todos fiquem "de rosto para a parede" para conhecerem a liderança do partido - que é inspirada na militante Vera Sílvia Magalhães. E ressalta: "vocês não podem olhar para o rosto dela até que sejam definitivamente do grupo". Todos obedecem. Quando Maria entra, apresentando-se como membro do MR-8, seu rosto é filmado com zoom-in até aparecer em primeiro plano. Enquanto continua falando, a câmera capta o rosto dos novatos, um por um. Ao aproximar-se de Fernando, a câmera se fixa no olhar dele para a lateral da sala, encarando um espelho por onde consegue ver Maria. A partir dessa cena, sabemos que ela será o par romântico do protagonista: a troca de olhares entre duas pessoas que mal se conhecem e parecem sentir certa mistura entre antipatia e admira-

8 Optei por utilizar, no decorrer da descrição do filme, os nomes originais dos personagens que já foram apresentados. 
ção, um dos mais conhecidos clichês das comédias românticas hollywoodianas!

Maria continua falando sobre o grupo, agora com uma entonação ainda mais forte, enfatizando que "as regras de disciplinas serão cumpridas sempre”. Comandados por ela, que ainda se apresenta numa postura rígida, todos vão à aula de tiros. É claro que a troca de olhares não fica suspensa na narrativa: observando os novatos usando a arma, apenas Fernando é criticado ao errar o alvo.

No retorno da aula, César diz ao amigo: "Que chatice! Agora só tá faltando ordem de recolher. Agora, a sargentinha... parece que cismou com você!". E Fernando responde: "É, ou ela tá querendo me fuder, ou tá querendo fuder comigo!”. Em seguida, quando estão comendo, diz à líder da organização: "A companheira pode atirar muito bem, mas comer sua comida é provar a verdadeira coragem revolucionária!".

Mas o tratamento dado à Maria como alguém digna de riso não se interrompe aqui. Ela é mostrada, até esse momento, como uma mulher dura, rigorosa, que fala firme. O que leva a acreditar que, para liderar um grupo guerrilheiro, é necessário "masculinizar-se", ou melhor, assumir certas convenções de masculinidade. Aos poucos, o filme passa a mostrar que ela possui características convencionalmente atribuídas à feminilidade: após uma cena de assalto (quando César é preso), Maria demonstra estar fora de controle e, aos gritos, diz que se arrepende por ter recrutado "idiotas". Todos estão preocupados com a prisão do companheiro, mas Maria parece surtar, dizendo "vamos todos morrer, isso não vai dar certo!".

Ainda no aparelho e nessa situação de tensão, Fernando, contrapondo-se à postura exaltada de Maria, parece ter tranquilidade suficiente para pensar na ideia de sequestrar o embaixador americano. Aprovada sua sugestão da façanha, altera-se o comando do grupo: dois militantes da ALN chegam para colaborar nessa ação, e Jonas passa a dar as ordens. Se o filme já mostrara que, embora severa, Maria era instável e poderia sair do controle a qualquer momento, é com a chegada de Jonas que ela pode amolecer para relacionar-se afetivamente e amorosamente com Fernando. Assim, ao perder os 
atributos que antes lhe davam destaque no grupo, perde também sua posição de importância na composição do filme. Em outros termos: na medida em que seus atributos de masculinidade são substituídos pelos de feminilidade, Maria se distancia do poder: na maioria das cenas que seguem, ela aparece como "apoio" ao protagonista, seu par romântico.

Além de Maria, outra personagem é inspirada na vida da militante Vera Sílvia Magalhães. É Renée, guerrilheira encarregada de obter informações sobre a rotina do embaixador. Vestida de modo simples, ela vai ao portão da residência do alvo e, de pronto, conversa com o chefe de segurança a respeito de uma suposta casa onde teria emprego e cujo endereço seria ali. Ele diz que vai ajudá-la a encontrar o local correto, e os dois vão a um bar. Enquanto tomam cerveja, ela descobre que "o embaixador é um homem bem simples, não gosta de segurança armada”. Saindo do bar, vão para a casa do segurança, onde ela pede outra cerveja, como se precisasse embebedar-se para fazer algo que não teria coragem em estado sóbrio. Renée procura uma música no rádio e começa a dançar - primeiro, para ele; depois, com ele. Chamando-a de "menina" enquanto dançam, o segurança diz: "Sabe que você é muito bonita? [...] Vocêé especial, faço qualquer coisa...". A câmera, que estava bem próxima ao enfatizar um tímido e inseguro sorriso de Renée, afasta-se. O corte da cena sugere que os dois transaram, e que a militante trocou seu corpo pelas informações recebidas.

Este não é o primeiro filme sobre a ditadura que retrata o uso do corpo da mulher em troca de favores ou informações. Se pensarmos no filme O bom burguês, dirigido por Osvaldo Caldeira (1983) enfocado na vida de um bancário disposto a desviar dinheiro para organizações armadas, esta situação ocorre duas vezes. Antônia, uma agente dupla, transa com o protagonista Lucas para obter informações e levá-las ao empresário Tomas, ligado à repressão. Diferentemente do filme de Bruno Barreto, aqui não há corte na cena: a câmera explora o corpo da mulher em cima de seu amante, assim como já explorara o corpo de Neusa na primeira cena em que ela aparece com o marido Lucas: primeiro seus seios, barriga e pernas 
são mostrados, depois o enquadramento aumenta para que se observe que estão transando. $\mathrm{O}$ segundo momento do uso do corpo ocorre exatamente com Neusa que, ao negociar a libertação de seu marido, mantém relações sexuais com um dos responsáveis pela repressão.

Retornemos, pois, ao filme $O$ que é isso, companheiro?. Na sequência seguinte à noite passada na casa do segurança, uma cena constrangedora mostra Renée desolada caminhando até um bar para usar o orelhão. Com o movimento de zoom da câmera, seu rosto é filmado em close com os olhos cheios de lágrimas ao ser rejeitada pelo pai, que desliga o telefone assim que ela se identifica. A respeito dessas imagens, Marcelo Ridenti (1997, p.23) afirma que:

Vera Sílvia descobriu o esquema falho de proteção ao embaixador, mas jamais se sujeitou a dormir com o chefe da segurança, como aparece no filme O que é isso, companheiro? de Bruno Barreto. O diretor assume essa 'liberdade poética', para dar mais dramaticidade à história, e mostra depois a menina frágil ligando para o pai, em busca de conforto, sem poder contar-lhe o ocorrido. O cineasta é livre para fazer o que quiser, mas sua versão ficcional é uma injustiça não só com a verdadeira Vera Sílvia, mas principalmente com as mulheres guerrilheiras, precursoras do feminismo no Brasil.

Essas cenas mostram também que a reconstrução realizada pelo filme é cúmplice à visão limitada que os militares e demais conservadores tinham em relação às mulheres. Mais que isso, tais imagens contribuem para uma estrutura fílmica que opta por trabalhar com estereótipos baseados no "bom roteiro", como diz Ismail Xavier (1997) - e, nesse sentido, a relação conturbada de Renée com seu pai é um ponto que se entrelaça à sua relação com o embaixador.

Após o sequestro, Renée passa a cuidar do ferimento do embaixador, conversando com ele sempre com grande dose de ternura - e na língua inglesa, atitude compartilhada apenas com Fernando. As cenas destacam as mãos de Renée fazendo os curativos cuidadosamente, enquanto ambos comentam sobre a esposa do sequestrado, a qual a militante elogia chamando-a de 'diva'. 
Em outro momento, uma sequência mostra as atividades que cada militante realiza no aparelho. Fernando está com Maria rodando cópias de algum texto. A câmera mostra Marcão fazendo exercício físico, e depois desliza para mostrar Júlio arrumando a arma para, em seguida, ler uma revista. Deitado, Toledo escuta música clássica - a mesma que percorre toda essa sequência.

Já Renée é filmada no banheiro, com um leve sorriso no rosto demonstrando sinal de satisfação: está lavando carinhosamente a camisa do embaixador. Afinal (e aqui a ironia é minha, e não do filme), que outras preocupações uma guerrilheira, repleta de atributos considerados por tempos como "naturais" ao sexo feminino, poderia ter, se não a domesticidade para agradar ao pai substituto? A carência afetiva da personagem, exposta da conturbada ligação ao pai, é deslocada para o embaixador sequestrado. Encontrar um homem para o qual possa oferecer e receber atenção, conciliando com diversas formas de cuidado, nas quais se reafirmam determinadas convenções de feminilidade, compõe o modo escolhido pelo filme para manifestar sua memória a respeito da militância feminina.

Para comparar novamente com $O$ bom burguês, tomemos como exemplo a personagem de Joana, irmã do protagonista. Militante de um grupo guerrilheiro, ela reconhece seu irmão no assalto ao banco realizado pela organização que participa. Acabada essa operação, os militantes - exceto seu companheiro - gritam com ela, afirmando que por sua culpa uma pessoa foi morta (o guarda do banco). Ela reconhece essa situação, diz "a culpa foi minha, eu vacilei quando vi meu irmão". Exaltados, eles dizem que ela deveria ser mais cuidadosa, que "militante não tem família, não tem irmão". Além de Joana, há mais uma mulher no grupo, mas esta permanece calada durante a discussão. Ou seja, apenas os homens a ofendem e a rebaixam. Diante dessa situação, Joana diz a seu companheiro sentir-se "uma criança" entre os demais participantes do grupo - e sua fragilidade e emotividade estão presentes nos demais momentos em que aparece no filme. 


\section{O intelectual e o operário}

O historiador Alex Barros Cassal, ao analisar filmes brasileiros das décadas de 80 e 90 cujos temas eram a militância política no período de ditadura militar, enfatiza que essas produções trazem à cena a figura do revolucionário - personagem-chave reconstruído pelo cinema através do mito do herói. De acordo com o autor:

[...] a natureza do herói é sempre a mesma: a luta, o enfrentamento. [...] Falo do herói como uma representação, um signo de ação, conflito, destruição, mudança, metamorfose. Ele faz as coisas acontecerem: decifra segredos, pega em armas, viola virgens, derruba reinos, mata dragões. Destruindo a velha ordem para criar a nova, o herói mostra um caráter fundamentalmente revolucionário, radical, pois não aceita mediações ou contemporizações - é o sujeito da história por excelência. (Cassal, 2001, p.8)

Após criar e enumerar diversos tipos-ideais de heróis do cinema brasileiro, Cassal destaca que "o herói é uma construção cultural típica do mundo masculino - ele é o guerreiro, caçador, fálico, dominador. [...] Ou seja: só os homens são heróis”. Como não trabalha em termos de relações de gênero, utiliza conceitos estanques ao atribuir o heroísmo ao sexo masculino. Mas isso não diminui a importância do assunto abordado por ele, que traduzo da seguinte forma: nos filmes baseados em estruturas tradicionais que seguem as fórmulas da grande indústria, o heroísmo está associado a convenções de masculinidade. Nesse sentido, mulheres também podem ser heroínas - desde que possuam características ligadas a tais convenções, como apontado no caso de Maria no início do filme de Bruno Barreto, quando assumia o papel de líder do grupo guerrilheiro.

Contudo, uma inquietação permanece: se as personagens femininas aparecem de modo tão infeliz como apontado nos parágrafos acima, será que coube um grau de complexidade maior no trato dos papéis masculinos? Vejamos os exemplos dos personagens de Fernando e Jonas. 


\section{DANIELLE TEGA}

Fernando, o protagonista, possui características ambíguas. Logo no início, ao criticar a comida preparada por Maria, mostra-se ousado. A mesma qualidade se repete no final do filme, quando, pendurado no pau-de-arara, responde de forma corajosa às gracinhas ditas pelo torturador. É o único que se recusa a usar capuz quando se relaciona com o embaixador, e conversa com este sobre diversos assuntos. Como Renée, os diálogos entre o protagonista e o sequestrado são na língua inglesa; porém, diferentemente dela, os temas abordados não se restringem à beleza da esposa do americano: falam de guerras, racismo, socialismo, liberalismo etc.

A inteligência de Fernando é destacada na escrita do manifesto, pelo qual recebe elogios rasgados de Maria, "orgulhosa” do companheiro - fato que revela outro atributo do personagem, já que conquistou a militante. E, mais importante, ele é o único do grupo de guerrilheiros a ter a maturidade de perceber que a luta armada está isolada.

Apesar dessas qualidades, Fernando também possui certas características que permitem considerá-lo, como faz Alex Barros Cassal (2001, p.34), uma espécie de anti-herói: "péssimo atirador (ao contrário de Lamarca), desastrado, indeciso, se indispondo com as lideranças da organização". Trata-se, portanto, de um personagem complexo, capaz de circular entre as posições de herói e de anti-herói. Essa ambivalência é a força do personagem, pois ele se utiliza ora de uma qualidade, ora de outra, em contraposição à figura chapada do guerrilheiro Jonas. ${ }^{9}$

Jonas, ex-operário e guerrilheiro da ALN convidado para comandar o esquema tático do sequestro do embaixador americano, assume a liderança dos grupos envolvidos. Trata-se de um personagem construído de modo bastante estereotipado, cujos momentos na tela cha-

9 No livro Versões e Ficções: o seqüestro da história (Reis Filho et. al., 1997), grande parte dos artigos reunidos dirige sua crítica ao filme de Bruno Barreto partindo do modo pelo qual o guerrilheiro Jonas, nome usado por Virgílio Gomes da Silva na clandestinidade, foi representado nas telas. 
mam a atenção pela arrogância e frieza. A cena da primeira conversa que trava com os demais militantes é exemplar de sua conduta exemplar não no sentido de ser mais forte, mas por ser a primeira de uma série de cenas que insistem em reafirmar as mesmas características do personagem.

Todos estão na sala quando Maria apresenta Jonas e Toledo. Sentados sobre o sofá, escutam atentamente as palavras, ou melhor, as ordens do comandante. Toda a operação deve ser feita de acordo com suas determinações. Se alguém vacilar, morre. Se alguém titubear em matar aquele que vacilou, também morre. Quando o personagem demonstra tamanha brutalidade ao lidar com os próprios companheiros, há que se imaginar o trato com o inimigo!

$\mathrm{Na}$ cena em que o embaixador é entrevistado, Jonas demonstra indignação com a presença de Fernando na sala. Maria justifica: o sequestrado recusa-se a falar em português; é necessário, portanto, a presença de um tradutor. Abro um parêntese: Renée também fala inglês e conversa com o embaixador em momentos posteriores. Por que a escolha de Fernando para o interrogatório e não a de Renée? Essa cena, que marca o início do coleguismo entre o americano e Fernando, não tem força para justificar tal deslize. Ele é escolhido apenas porque precisa cumprir seu papel de protagonista, e sua presença em momentos marcantes permite que o filme mostre suas qualidades. Fecho parêntese.

Jonas, como observado, está irritado. Fazendo um contraponto com Fernando, que, mesmo com certo nervosismo diante da situação, sabe permanecer controlado, o ex-operário apresenta-se como um desequilibrado: encosta o cano da pistola na cabeça do embaixador, insinua a possibilidade de torturá-lo, ameaça por diversas vezes matá-lo. Sempre gritando e exacerbando sua fúria.

O contraponto com Fernandoé também declarado quando Jonas passa a vê-lo como um adversário. Com poder por ser o líder da operação, Jonas já decidira que Fernando não participaria do momento do sequestro. É ele quem também falsifica a escala de vigia ao embaixador para que seja Fernando o assassino caso as negociações com o governo fracassem. 


\section{DANIELLE TEGA}

Pela relação estabelecida entre os dois militantes, pode-se verificar que a complexidade de elaboração do personagem de Fernando ocorre na mesma proporção que o de Jonas é diminuído. No embate entre os dois modelos de masculinidade, ganha força aquele que sabe lidar com as circunstâncias para circular entre as trilhas do que seria considerado heroísmo e anti-heroísmo, dado que esta última característica é positiva quando comparada às ações grotescas de Jonas. Trata-se de uma escolha do filme ao manifestar sua interpretação do passado recente: O que é isso, companheiro? opta por valorizar o intelectual em detrimento do operário, como bem apontou Alex Cassal (2001).

Tal como Jonas, outro revolucionário é reconstruído nas telas brasileiras sem que se leve em conta toda a complexidade existencial que o cercava. O filme Lamarca, de Sérgio Rezende (1994), reconstrói a trajetória do militar que deixou o exército para militar em organizações guerrilheiras, pertencendo àVPRe, meses antes de morrer, ao MR-8. Apresentado de modo pouco denso, suas falas parecem artificiais, como se retiradas de algum manual. Fala de modo empossado, é exímio nas atividades que realiza-eé assassinado quando já estava morto por dentro, sem forças, com os braços abertos, tal qual um Cristo.

Na longa trajetória de Lamarca, o filme mostra o militante chegando ao final praticamente transfigurado, mas como um homem digno em todos os momentos, sem contradições, pensando apenas a revolução. Em seu relacionamento com Iara, há certo espaço para que o herói possa ser humanizado. Mas uma barreira impede tal acontecimento, pois a própria guerrilheira é reconstruída de modo a ser apenas uma sombra de Lamarca. Na personagem de Iara, o filme retoma duas versões da repressão: a) ela aparece como a "amante" de Lamarca, e não como uma companheira intelectual, sedutora e questionadora; b) o cineasta optou por mostrar uma cena em que Iara se suicida, ponto debatido por seus parentes e testemunhas desde a divulgação de sua morte. ${ }^{10}$

10 Ao reafirmar na tela a versão oficial do suicídio de Iara, o filme não deixa margens a outras interpretações de sua morte. Após exumação do corpo de Iara em 


\section{A tortura. Ou: o trabalho burocrático}

No filme de Bruno Barreto, a repressão parece se reduzir a um grupo de militares decididos a acabar com aquela baderna juvenil. Em nenhum momento ela é percebida como uma política de Estado, que ia muito além do combate aos grupos guerrilheiros e que, na verdade, se utilizava desse combate para imobilizar e massacrar toda oposição a regime, impondo o autoritarismo pelo medo.

Os dois torturadores da ficção são vistos pela primeira vez após a captura de César. Arrastam o prisioneiro - já machucado pelo tiro que o acertou no assalto ao banco - pelos corredores de uma instituição que não se sabe qual é. E levam-no à sala de tortura. Numa cena plástica, seca, sem luz de fundo, os agentes da repressão afogam o guerrilheiro com o objetivo de conseguir informações sobre os demais participantes do assalto. Enquanto aguardam respostas, travam conversas cotidianas entre um afogamento e outro. Parecem estar batendo carimbos, ou fechando envelopes, enquanto perguntam entre si sobre as respectivas esposas. Na verdade, estão destruindo a vida de uma pessoa, retalhando corpo e alma, destituindo-lhe de sua humanidade e subjetividade.

Como disseram as depoentes do filme de Lúcia Murat, "a tortura é suja". Mas, aqui em $O$ que é isso, companheiro?, ela aparece como uma tarefa a mais que deve ser feita, um acidente, um excesso necessário para desmantelar, nas palavras de um dos torturadores, grupos de "jovens ingênuos iludidos por uma canalha de dirigentes desonestos e mal-intencionados". Desnecessário enfatizar a referência exposta na frase a Renée e Jonas: seus personagens são construídos de modo que possam ser perfeitamente encaixados nessa fala do torturador.

Em outro momento do filme, os dois torturadores cumprem a tarefa de vigiar o aparelho no qual se encontram os guerrilheiros e o sequestrado. Enquanto aguardam o desenrolar dos fatos debruçados numa sacada, travam o seguinte diálogo:

2003, olaudo pericial de 16 de maio de 2005 revelou ser "improvável que a morte de Iara Iavelberg tenha ocorrido por suicídio”. Cf. Corsalette, 27 jun. 2005. 
1: Soube o que aconteceu com o Peçanha?

2: Quem?

1: O Sargento Peçanha.

2: Não. O quê??

1: Casou com a Marta.

2: Que Marta?

1: Aquela magrinha, ruiva.

2: Quem, a terrorista?

1: É, ela mesma. Casaram ontem, de papel assinado e tudo. Vão morar em Honório Gurgel.

2: Esse aí pegou gosto pelo ofício da tortura. Acabou encontrando o prazer que nunca teve no trabalho burocrático.

1: Eh, Peçanha safado. A Marta sempre foi a predileta dele.

Ora, se já não bastasse a tortura ser exposta como algo desvinculado aos escalões superiores do comando das Forças Armadas, como algo realizado com o intuito de livrar "jovens inocentes" dos "dirigentes mal-intencionados", agora a violência de gênero na tortura é manifestada pelo avesso: a mulher torturada, Marta, casou-se com seu algoz, Peçanha. Embaraçoso tecer considerações a respeito desse diálogo. Não há vestígios para que se pense sobre o perfil da militante (chamada por eles de terrorista, claro!), como também não há questionamentos sobre a perda de sua subjetividade numa situação que poderia produzir um "outro sujeito" no lugar do "sujeito real".

No fundo do enquadramento feito na varanda, há apenas a noite e a lua. Símbolos utilizados em histórias românticas "à luz do luar". O que o diálogo acima deixa latente é que torturada e torturador gostaram do tipo de relação que estabeleciam, e resolveram estendê-la por mais tempo. Com isso, as violentas marcas que a tortura deixa são exibidas com uma suavidade difícil de ser concebida.

É certo que, na cena final do filme, quando Maria aparece na cadeira de rodas no aeroporto, todas as cicatrizes da tortura parecem expostas. No entanto, essa mesma cena também tem como objetivo suavizar a tortura. Tal paradoxo ocorre porque, enquanto Maria caminha em direção a outros militantes que serão levados ao exílio, sua voz-over revela informações que passam a ser discretas dado o 
impacto da imagem de sua condição física. Trata-se do assassinato do guerrilheiro Jonas, torturado até a morte.

Cabe destacar que $O$ que é isso, companheiro? não foi o primeiro filme a tratar a tortura de modo completamente desvinculado de todo aparato autoritário construído pelos altos escalões da ditadura civil- militar. O filme Pra frente, Brasil, de Roberto Farias (1982), aborda de forma explícita a repressão na rua e cenas de tortura, incluindo a participação de empresários em tal prática. Mas a reconstrução que faz do período mostra os torturadores como parte de um grupo paramilitar de direita - o único militar presente no filme é o mesmo que fica "perplexo" ao saber da existência desse tipo de situação, tida pelo filme como excessos e não como regra. ${ }^{11}$ Dissocia-se, assim, violência e Estado, tal como o filme de Bruno Barreto.

\section{Estranhas as marcas que deixamos sem perceber}

Quando pensamos na manifestação da memória de um período, como no caso dos filmes brasileiros que abordam a ditadura militar, percebemos a dificuldade que estes demonstram em lidar com o passado: são películas que permanecem à descrição (construída) dos fatos ocorridos, mas sem trabalhar uma articulação a partir do passado. Para Ismail Xavier (1993, p.115), um dos maiores problemas dessas películas consiste no fato de que

Em particular, determinados gêneros apareciam como eficientes soluções de compromisso pelas quais se permitia a denúncia das iniquidades canalizada para uma catarse que, longe de ameaçadora, era fator de equilíbrio, porque oferecia uma expressão domesticada, reconfortadora, a determinadas inquietações presentes no seio da sociedade.

11 Após anos de seu lançamento, e com muitas discussões e pesquisas a esse respeito já divulgadas, que demonstram o caráter sistemático do uso da tortura enquanto prática repressiva, o cineasta Roberto Farias afirma que ainda concorda com a opção feita em seu filme a respeito da tortura. Em evento realizado 
Os filmes cujas narrativas são próximas à decupagem clássica, como os político-policiais, têm como característica a produção do ilusionismo e do mecanismo de identificação. Nesse sentido, ocultam o caráter estrutural da dominação que compõe as relações sociais, "naturalizando-as". Aprofundando essa observação, é pertinente afirmar que a opção feita por esses filmes para manifestar a memória do passado está baseada no modo pelo qual as relações de gênero são construídas nessas películas.

Esse tipo de escolha cria barreiras em relação às diferentes possibilidades de representação de feminilidades e masculinidades. São construções cinematográficas que oferecem pouco espaço para questões ligadas às complexidades femininas, já que se orientam pela ação ficcional, culturalmente atribuída ao masculino - nem mesmo questões referentes às convenções de masculinidade escapam dos limites impostos pelas narrativas inspiradas nas fórmulas tradicionais americanas: certos papéis podem ser mais elaborados (como o personagem Fernando, de O que é isso, companheiro?) enquanto outros são representações estereotipadas e com pouca complexidade (como Jonas, do mesmo filme). Se a militância é reconstruída de tal forma, o escopo sociocultural sofre da mesma falha.

Dadas essas características, Ismail Xavier (2001) afirma que esses filmes possuem limites claros para a discussão da experiência social. Parece-me interessante, portanto, retornar ao filme de Lúcia Murat para que as possibilidades e limites da linguagem do documentário performático também sejam verificadas ao lidar com essa discussão. Boa parte desse estudo foi realizado no capítulo anterior, mas gostaria de retomar o tema da tortura e problematizá-lo com os novos apontamentos feitos nas ponderações das ficções político-policiais. Como estamos no terreno da memória, não podemos nos esquecer de que o resgate do passado deve ser acompanhado pelas questões postas no presente, mas com perspectiva futura. Assim,

na USP no final de 2007, ele disse não acreditar que os militares de alto escalão soubessem da existência desse "procedimento". 
discuto num segundo momento a questão que ficou pendente no capítulo anterior: como o futuro é articulado em seu labirinto da memória? Como são várias as possibilidades para encontrar a saída de labirinto, muitas vezes retornaremos ao passado ou ao presente do filme.

\section{Um sentimento de indignação muito forte}

Estamos, novamente, no filme de Lúcia Murat, no momento em que o cotidiano de Regina, uma das depoentes, nos é mostrado. A câmera percorre a participação da militante no Centro de Atividade Infantil, onde um grupo de mulheres da Baixada Fluminense se reúne para discutir e agir contra a violência - uma interlocução com a fase do movimento de mulheres, que o feminismo também foi ao encontro no período posterior à luta armada, bem como novamente com o tema da violência, uma das questões que tiveram destaque no feminismo dos anos 1980, como já destacado. A sequência mostra algumas mulheres entrando na sala do encontro enquanto ouvimos de Regina algumas palavras sobre a continuidade da organização. À sua voz, sobrepõe-se a seguinte narração em voz-over:

Da experiência de tortura, ficou em Regina um sentimento de indignação muito forte, e a necessidade de transformar seu trabalho como educadora numa briga constante contra a violência. Como na organização dessas mulheres na Baixada Fluminense, onde foi encontrar a pior forma de tortura, aquela que está tão impregnada no dia a dia que sequer merece destaque.

Após essa narração, o filme mostra o depoimento de uma moradora do bairro onde Regina realiza o trabalho com o grupo de mulheres. Esta é a única pessoa entrevistada que não se refere diretamente a qualquer depoente. Perto de um cerca, em cima de um morro, a câmera enquadra o corpo todo da moradora quando esta afirma: 
Isso não me choca porque a violência na Baixada Fluminense é maior do que uma tortura política. A 500 metros daqui, há um ponto de desova. E os nossos filhos convivem com isso no dia a dia. Não é dizer que não choque a gente, mas amortece.

Corta. Sobre esse mesmo assunto, acrescenta Pupi, que trabalha como médica sanitarista no mesmo bairro:

[...] a situação-limite que eu cheguei na tortura, essa coisa da gente se sentir um pedaço de carne, não ter sentimento, eu enxergo muito no dia a dia do pessoal da Baixada. Eu acho que a pressão cotidiana, a vida é tão torturante que há uma certa identidade. Quando falo que fui presa ou qualquer coisa ligada à tortura, as pessoas não têm muita emoção, é uma coisa meio que natural.

Pela exposição das duas primeiras falas, observamos que a voz- over de Irene Ravache praticamente fez uma repetição do que seria dito pela moradora, num processo de busca e identificação às classes populares. Nesse sentido, cabe pensar na relação das esquerdas do final dos anos 1970 com os novos movimentos sociais que entravam em cena. ${ }^{12}$ Militantes que saíam das prisões ou voltavam do exílio encontravam nesses grupos uma nova forma de pensar a esquerda, sem a verticalidade dos partidos. Criam-se outras expectativas para se pensar a luta política, como o novo sindicalismo, que apresentava debates internos para sua organização.

Esses novos movimentos lutavam contra todo tipo de ditadura, tanto do Estado como dos partidos. Assim, não tinham líderes únicos, mas representantes rotativos. Em voga, a ideia de autogestão, de autonomia, de novas formas de fazer política.

Se pensarmos no caso do movimento de mulheres, como o grupo retratado pelo filme, observamos que, a princípio, não era feminista. Lutavam por creches, asfalto, esgoto, numa união de moradoras

12 Para um estudo sobre os movimentos dos anos 1970 e 1980, ver: Sader, 1988. Ver também: Telles, 1986. 
de determinados bairros para reivindicações cotidianas. As questões feministas entraram em pauta posteriormente, numa aproximação frutífera para ambos os grupos, apesar das dificuldades nessa relação devido aos fortes vínculos do movimento das mulheres com a Igreja Católica. Há que se ressaltar a importância das Comunidades Eclesiais de Base como um espaço politizado nas igrejas, possibilitando a discussão sobre a ditadura. Mas muitos limites estavam colocados - embora certo radicalismo ocorresse em algumas alas da igreja, como pode ser verificado na trajetória da teóloga feminista Ivone Gebara. ${ }^{13}$

De um modo geral, quando esses movimentos sociais surgiram, foram vistos com grande expectativa. Muitos intelectuais acompanharam de perto a formação de muitos desses grupos, interagindo também enquanto militantes. ${ }^{14}$ Mas uma série de críticas após o período inicial passou a considerá-los localistas e clientelistas, críticas que se agravavam também por outras questões, já que também ocorria, naquele momento, uma "progressiva desmobilização ou integração à ordem dos movimentos sociais na medida em que partidos de oposição à ditadura chegavam a prefeituras e governos" (Ridenti, 2000, p.340).

E o filme de Lúcia Murat dialoga com essa aproximação aos movimentos de duas formas: ao mostrar o cotidiano de Regina, que participa da organização de um desses grupos; e ao entrevistar a moradora da Baixada Fluminense, bairro onde ocorrem as reuniões filmadas.

A identificação da fala em voz-over de Irene Ravache ("a pior forma de tortura..., impregnada no dia a dia") à fala da moradora ("a

13 Agradeço à professora Margareth Rago pela cópia de um texto ainda não divulgado sobre sua atual pesquisa, no qual encontrei a referência sobre algumas militantes feministas, entre elas, Ivone Gebara.

14 Para um estudo da aproximação dos intelectuais a esses movimentos, ver Ridenti, 2000. No último capítulo, o autor destaca a presença do cineasta Renato Tapajós articulado às greves do movimento operário, e o envolvimento do ator Celso Frateschi com a criação de grupos teatrais populares. 
violência na Baixada Fluminense é maior do que a tortura política... Convivem[os] com isso no dia a dia") apresenta um ponto inquietante, um lapso do filme. Perde-se uma oportunidade de problematizar essa questão num âmbito de classe, verificando a complexa relação entre a tortura política usada pela ditadura e a tortura policial presente nas comunidades carentes, ou seja, não há discussão da violência enquanto prática sistemática e política de Estado.

Essa separação agrava ainda mais um problema já abordado nos filmes político-policiais, que, como vimos, reconstroem a tortura como "excesso", e não como parte do planificado aparato repressivo da ditadura. O ponto fundamental que ambas as situações deixam de lado é que a tortura fazia parte de um projeto maior para a repressão e o controle de toda a sociedade, projeto este que tinha como base, além da polícia política, também a censura, a propaganda política e as sentenças autoritárias aos considerados 'subversivos'. Esse conjunto de mecanismos impõe a intimidação e o medo à população, e como afirma Carlos Fico (2004, p.81-81),

É a análise conjunta de todos estes setores que possibilita a percepção da complexidade da estrutura, pois ela esteve longe de poder ser subsumida na noção de 'porões da ditadura', que tende a homogeneizar o que, afinal, possuía diferenças significativas. [...] É esta oficialização da prática da tortura (que vários observadores preferem chamar de 'institucionalização') que desmente as hipóteses de 'autonomia' e dos 'excessos'. É rigorosamente impossível que a atividade sistemática da tortura pudesse ser praticada dentro de unidades militares sem o conhecimento de seus comandantes. Os martírios demandavam equipamentos e instalações permanentes, sendo inviável [tal prática] sem o conhecimento dos oficiais-generais.

As engrenagens da ditadura mantinham em funcionamento a lógica do horror da tortura, racionalmente e hierarquicamente organizada, numa dinâmica onde "o calvário de dezenas é suficiente para que a sociedade em seu conjunto seja afetada” (Vinãr apud Cardoso, 1997, p.477). Nesse sentido, pode-se dizer que o alvo é mais a coletividade do que a própria vítima. Essas considerações auxiliam 
a pensar sobre o modo ambíguo pelo qual o filme de Lúcia Murat apresenta a permanência da ditadura na sociedade. Sobre isso, faço duas reflexões.

Por um lado, como foi observado no segundo capítulo, os depoimentos, as imagens, as indagações, as dificuldades de respostas: no âmbito individual e no coletivo, as vivências dessas mulheres trazem as cicatrizes da ditadura - tanto nos devaneios dos monólogos como na tentativa de articular uma explicação, que muitas vezes acaba por não se completar, pois o trauma permanece. Quando outras pessoas que pertencem ao mesmo meio social das depoentes fazem seus comentários a respeito da tortura, demonstram que preferem enxergar por um viés otimista a continuação da vida dessas mulheres. Frases como "ela superou, tem dois filhos lindos" ou "ela é uma pessoa normal que está a mil na vida” parecem comprovar a angústia das depoentes: "As pessoas acham que tudo já passou há muito tempo", "Acho que as pessoas que não passaram por isso, que não tiveram uma pessoa desaparecida, não enxergam a importância da questão”.

Sob esse prisma, o filme parece reatualizar a lacuna social entre os grupos guerrilheiros e "o povo brasileiro", para o período pós- ditadura: essa falta de conhecimento de parte da população, mesmo daqueles que convivem com as ex-militantes, demonstra que permanece um hiato, agora ancorado no silêncio ou no esquecimento impostos pela "transição transada para a democracia, que em nada minorou os graves problemas sociais brasileiros" (Ridenti, 2000, p.249), e pela lei da anistia, que não puniu os torturadores.

A permanência do hiato não deixa de ser uma autocrítica da própria luta armada; assim como a densidade subjetiva do filme é também uma autocrítica aos projetos políticos que não levavam em conta questões como a politização do privado. Nesse sentido, Que bom te ver viva é um importante trabalho de recuperação desse passado para reavaliá-lo.

Por outro lado, esta situação não se dá sem tensões. Quando a própria cineasta identifica-se com as palavras da moradora da Baixada Fluminense, deixa de enfatizar que o legado destrutivo da ditadura, que permanece nos corpos e nas (difíceis) vivências das ex- 
militantes, perpassa de forma devastadora toda a realidade social. A violência e a tortura na Baixada Fluminense não são "maiores" ou "piores" que a tortura política, ou seja, não se trata de quantificá-las ou de qualificá-las. Na verdade, trata-se da consequência da interrupção de uma proposta política que poderia ter desencadeado um outro tipo de organização social, menos desigual e alienada, mas que foi impetuosamente suspensa com o golpe civil-militar. Como sintetiza Marcelo Ridenti, recuperando o tema desenvolvido por Florestan Fernandes,

O processo da revolução burguesa - na sua especificidade autoritária e dependente, numa sociedade com desenvolvimento desigual e combinado, como a brasileira, em que o atraso é estruturalmente indissociável do progresso, o arcaico inseparável do moderno - seria coroado com o movimento de 1964. (Ridenti, 2000, p.51)

Desse modo, em nome de uma segurança nacional que era indispensável para o tipo de desenvolvimento econômico proposto (que seria posteriormente denominado de milagre brasileiro), a repressão atinge seus opositores com a mesma brutalidade que agride as classes subalternas - classes estas que continuam a ser violentadas nos dias de hoje. A ditadura não foi, portanto, um momento patológico da sociedade brasileira, mas sim uma trajetória do sistema socioeconômico excludente que adquiriu diferentes configurações institucionais em outros períodos. Mesmo finalizada a ditadura, há continuidade tanto nos esquemas de sustentação das classes dominantes como no estilo de ação dos agentes políticos e policiais, que permanecem bem instalados no tecido social.

Nesse sentido, é nas palavras de Pupi, quando aproxima a situação-limite que passou na tortura à pressão cotidiana na vida torturante dos moradores da Baixada, que encontramos ambas as circunstâncias percebidas como frutos de uma mesma estrutura de violência - $\mathrm{O}$ que me parece mais sensato que a voz-over de Irene Ravache.

Cabe ressaltar que a trajetória da cineasta parece dar uma resposta a esse lapso. Quando filma Quase dois irmãos, mostra de for- 
ma mais complexa as relações entre tortura e violência, ambas como parte de uma mesma estrutura histórica. Contudo, há uma proximidade desse trabalho de Lúcia Murat ao gênero policial-político, cujos limites já abordamos neste capítulo.

\section{O labirinto da memória: como será o amanhã?}

Ao colocar em cena as mulheres que participaram da resistência política à ditadura, Que bom te ver viva as mostra como sujeitos históricos. Em determinada sequência, quando Rosalina vai à festa, há uma montagem de imagens que, com o fundo musical, colocam todas as depoentes participando desse mesmo evento. Breves frases de cada uma delas intercalam-se às imagens da festa quando, nessa união de fragmentos, a voz-over de Irene Ravache diz: "Foi quando você me olhou e disse: Que bom te ver viva!".

Essas imagens, recortadas e reunidas, indicam que a resistência não foi uma atitude isolada, mas um ato coletivo. Como afirma Maria Auxiliadora de Almeida Arantes (1997, p.441), "Cair na clandestinidade não foi uma decisão individual, foi uma decisão política, e o ato de ser clandestino, o cumprimento desta decisão”.

Eu acreditava que ia conseguir transformar o mundo [...] como na organização em que militava. Hoje sei que tenho limites. Vale a pena transformar o mundo num mundo melhor; mas acho que, hoje, as coisas são diferentes. O passado que buscava uma emancipação revolucionária, e as restrições impostas pelo presente.

Com essas frases, Pupi revela as diferenças entre um passado que buscava coletivamente a transformação revolucionária e as restrições que se encontram no presente. Novamente vemos a difícil tarefa de tramar os fios da memória, como na voz-over da narradora:

Continuar. Uma palavra mágica que parece negar tudo o que mudou. $\mathrm{O}$ caminho feito entre a liberdade dum ato e as esquinas paulistas. Entre a onipotência da guerrilha e as reuniões das mulheres onde se dis- 
cute as políticas do dia a dia. A dimensão trágica virou coisa do passado, e qualquer tentativa de ligação lembra um erro de roteiro.

Nessas contradições da memória, quando as diferentes vozes parecem ser de apenas uma, é também o momento onde a voz de cada uma se amplifica como se fosse a das demais. Entrelaçando o âmbito individual e o coletivo, já não importa identificar quem disse cada frase - pertence a todas àquelas que continuam comprometidas com a luta política:

Saudades dos companheiros que lutaram.

Ainda acho que vale a pena lutar por um mundo melhor.

Eu persisto na cobrança, eu continuo cobrando. Eu não fiz parte deste acordo de silêncio.

Eu sou profundamente radical nisso. Se eu encontrar torturador, faço um escândalo não importa onde estiver.

É uma luta manter a denúncia.

Não tem esse negócio de esquecer não. Não tem mesmo. Pronto.

Se o trabalho de articular o passado ao presente não é dos mais fáceis, principalmente quando se refere a um período traumático, pensar nas possibilidades futuras parece ser tarefa ainda mais difícil. Na luta do presente, a denúncia, a recuperação da luta do passado. Mas como projetar o futuro? Parece-me que o próprio filme não encontra resposta para isso. Mesmo na sequência da festa, a música escolhida como fundo deixa esse ponto em aberto:

Como será o amanhã? / Responda quem puder / O que irá me acontecer? / O meu destino será / Como Deus quiser. / Como será? [...]

E a melancolia presente no último monólogo, fechando o filme, reafirma essa falta de perspectiva futura: "Não sei como é essa história de que a vida continua, mas ela continua”, diz a personagem, enquanto se aproxima das grades de uma janela. $\mathrm{Na}$ tela, vemos a parede, a janela, as grades e a narradora - presa novamente? O monólogo é finalizado: 
Mas hoje eu não quero pensar nisso não. Eu vou sair, acho até que vou tomar um porre, vou descolar um gato, mesmo que amanhã de manhã eu tenha que avisar: olha, cara, vai com cuidado, vai com cuidado que já me machucaram pra caralho. É, eu acho que é isso, eu devia pôr uma placa: cuidado, cachorro ferido.

Por hoje, bastou toda a dor da recordação. Se a vida continua, e não se sabe como o amanhã será, hoje não é o melhor dia para pensar nisso. No labirinto da memória criado pelo filme, os traçados que podem levar à saída para o futuro, ou seja, para uma perspectiva libertadora, possuem obstáculos ainda mais espinhosos para serem vencidos. 



\section{Considerações Finais}

Em um artigo chamado $O$ pessoal é politico: desventuras de uma promessa subversiva, Eleni Varikas (1996) faz uma análise sobre o pensamento e as práticas feministas, da qual cito dois momentos.

"Ainda não estando as coisas" [Rebus non iam stantibus] definiria um momento em que o feminismo estaria marcado pela necessidade de repensar as instituições patriarcais, o questionamento sobre a repressão ou regulação autoritária dos sentimentos, da sexualidade, da paixão amorosa, acentuando a necessidade desses temas para se pensar na capacidade de autonomia e subjetividade, fundamentais à política, inclusive à política 'revolucionária'. Tratava-se de uma proposta que subvertia a separação atual entre privado e público. Sua referência à felicidade encontrava na utopia socialista da primeira metade do século XIX um terreno propício para se expandir. Dizia respeito às alternativas possíveis, àquilo que "pode ser" mas que "ainda não é": "este horizonte dos possíveis no qual a utopia busca sua força", como complementa a autora.

"Assim estando as coisas" [Rebus sic stantibus] relaciona-se a um momento que, em vez de subverter, parecia racionalizar a dicotomia público x privado, e se manifesta na "ênfase colocada por várias correntes feministas na conciliação entre vida profissional e vida familiar”. Está em pauta uma preocupação em melhorar as condições 
das mulheres "como elas estão hoje". Quando o questionamento sobre o privado e o público não acompanha uma reflexão sobre outros horizontes possíveis, a referência à felicidade tende a ser subestimada pela crítica feminista, diferente das utopias anteriores para as quais a felicidade estava no centro de sua reelaboração do político.

A longa citação justifica-se pela maneira que a autora sintetiza a relação entre as duas posições:

Ora, a parte de felicidade que 'cada ser social tem direito de pedir da sociedade' é precisamente o que permite transformar o rebus sic stantibus [assim estando as coisas] em rebus non iam stantibus [ainda não estando as coisas], neste "ainda não" graças ao qual a utopia se inscreve no aqui e no agora, nas 'expectativas de uma época ou de um grupo social'. E esta inscrição só é possível pelo trabalho que consiste em explorar, dentre as possibilidades abertas pela utopia, aquelas que parecem corresponder aos desejos, aspirações e necessidades negados ou não realizados. $\mathrm{Na}$ ausência de uma tal exploração que transforme as necessidades e as expectativas em 'ideias-guias que orientam as esperanças e mobilizam as energias coletivas', a utopia corre o risco de se converter em seu contrário, em amor fati, esta vingança imaginária da impotência, que transforma a necessidade em virtude. É nisto também que o "pessoal" é "político" ou ao menos comunica-se com ele. [grifos da autora]

Inspiro-me nessas observações de Eleni Varikas sobre o "ainda não estando as coisas" e o "assim estando as coisas" para tecer minhas considerações finais.

Os filmes abordados neste livro retratam uma geração em busca da utopia do homem novo, que exigia uma nova concepção de moral e ética, de justiça social, de uma nova sociedade, a socialista. Com o feminismo, ampliou-se essa utopia à mulher nova, e a uma sociedade que, além de socialista, fosse também libertária, formada por homens e mulheres livres, emancipados. Os grupos guerrilheiros buscavam a construção de uma nova sociedade no Brasil: era o "ainda não estando as coisas”, a vontade de mudar, a transformação, a revolução, que vinham num contexto mais amplo de revoluções em 
outros países, como Cuba e Vietnã. Eram grupos que procuravam "assaltar o paraíso".

Recuperar esse passado, essa vontade de transformação que permeava os diferentes grupos guerrilheiros, tem um forte sentido político quando o que se busca não é uma "ilusão a ser esquecida", mas sim uma utopia a ser resgatada (Ridenti, 1997, p.17).

Ao observar os filmes brasileiros político-policiais que se preocuparam em manifestar esse passado, percebe-se que trabalham com convenções de feminilidade e masculinidade numa fórmula que recupera o gênero tradicional cinematográfico, mostrando personagens geralmente pouco complexos. Essa opção dificulta uma perspectiva estética de real resgate do passado, ou seja, de articulação-e não mera 'descrição' sob qualquer ponto de vista - dos eventos ocorridos. Tal situação interfere na representação que fazem da militância, cujas contradições não são problematizadas. Ao contrário, nos conflitos que cercam a memória, esses filmes muitas vezes acabam reificando versões cúmplices ao processo de conciliação que se deu entre a sociedade brasileira e a ditadura.

Se pensarmos no documentário de Lúcia Murat, alguns avanços em relação a esse resgate foram feitos, principalmente a partir de dois pontos: a) pelo modo paradoxal que certas convenções de feminilidade são trabalhadas; b) pela forma como trabalha questões caras ao pensamento feminista, dando visibilidade às mulheres enquanto sujeitos históricos a partir de uma opção estética que une o afetivo ao histórico, o individual ao geral, politizando o privado.

Que bom te ver viva propõe um exercício de memória que, convocando as militantes a contar sua experiência de sobrevivência à tortura, enlaça de modo particular passado e presente. Ao construir a história de sua resistência e prisão, cada uma delas desenvolve reflexões e expõem sentimentos, nem sempre manifestos, que estão relacionados à forma pela qual deixaram em segundo plano determinadas preocupações em nome de uma luta coletiva. Pois a forma fílmica que mostra cada rosto em primeiro plano, cada fala de modo límpido - as músicas reforçam alguns momentos, mas não estão sobrepostas às vozes -, revela a intensidade emocional que parece ter 
sido policiada nos anos de militância - e que, em certa medida, se repetem quando saem da prisão. Pupi afirma que não conseguiu falar sobre a tortura com companheiros do presídio; Estrela diz ter dificuldades em tocar nesse assunto em sua casa.

Refletir sobre suas condições de mulheres que participaram ativamente na militância armada as leva também a pensar sobre os limites e alcances do discurso revolucionário que nutria essa militância. E isso se mostra de forma latente em todo o filme.

Contudo, no labirinto de memória que constrói, os caminhos para a saída emancipatória são difíceis de ser encontrados. O que demonstra a dificuldade em recuperar os projetos não cumpridos e reinscrevê-los novamente em um "ainda não estando as coisas".

Essa questão não é restrita à cineasta, mas se encontra no próprio momento histórico. Nesse sentido, a fragilidade observada em Que bom te ver viva pode ser interpretada, por outro lado, como o ponto revelador do filme: manifesta a característica do período em que foi feito, num momento histórico paradigmático marcado por tensões, assim como o próprio documentário. Se há ebulição social em torno da Constituição de 1988, há também uma falta de esperança das esquerdas marcada pela queda do Muro de Berlim; se há uma confiança em torno da campanha do PT e de Lula, tem-se na vitória de Collor um novo desalento para a esquerda. Trata-se, portanto, de um momento de refluxo e recomposição das esquerdas - que não se restringia apenas às brasileiras -, observado desde anos anteriores. Como afirma Marcelo Ridenti (2000, p.335),

A partir dos anos 70 e sobretudo dos 80 , houve uma tendência ao refluxo das utopias revolucionárias, embora aflorassem manifestações como a revolução nicaraguense e o surgimento do PT. [...] Os anos 90 foram a culminância do processo, lento e progressivo, de esvaziamento das utopias revolucionárias de artistas e intelectuais [...].

O período pós-ditatorial, marcado pelo neoliberalismo, pela violência policial permanente, com discriminação das minorias, foi marcado por algumas continuidades e outras rupturas - sempre 
acompanhadas pelas políticas de esquecimento. São novas conjunturas sociais e políticas, que produzem modificações nos marcos interpretativos para a compreensão da experiência passada e para a construção de expectativas futuras. Nesse sentido, a construção de expectativa futura é enevoada pelos processos reconciliatórios. Assim, as tensões presentes no filme são reveladoras no sentido em que trazem elementos complexos e ambíguos, mas característicos do seu contexto de produção.

Não há que se esquecer, por outro lado, as barreiras encontradas no próprio ato de narração do trauma: a dor, as feridas, as cicatrizes. O paradoxo do qual já alertava Adorno sobre a impossibilidade e, ao mesmo tempo, a necessidade de narrar. As memórias narrativas, ao mesmo tempo em que podem encontrar ou construir os sentidos do passado, quando vindas de acontecimentos traumáticos, possuem feridas que dificultam tal construção. A violência sofrida e a derrota dos projetos empreendidos fazem com que essas depoentes revisitem a experiência da militância de um outro lugar. Nessa revisão, a maternidade tem um papel muito importante.

Recuperar essas histórias pode ter um sentido emancipador quando são incluídas nas lutas atuais. São 30 anos da Lei da Anistia, uma lei que, para usar a expressão de Ismail Xavier (1997), "fez do passado letra morta", pois os torturadores não foram punidos. Na Argentina houve algum tipo de elaboração do terror político por ocasião do julgamento dos militares, da promulgação da Lei da Obediência Civil e depois da Lei do Ponto Final. Trata-se, sem dúvida, de um processo interrompido, mas que "durante sua vigência, permitiu, de algum modo, sua inscrição na história daquele país”, como explica Irene Cardoso (1997, p.483).

O mesmo não ocorreu no Brasil, tendo como efeito um obscurecimento maior da compreensão do legado destrutivo da ditadura. Sem punições e sem grandes manifestações por punições, o grau de ressentimento é maior - e, com isso, os momentos de utopia são ainda mais difíceis de ser realizados.

Os debates atuais em torno da Lei da Anistia não devem ficar restritos aos ex-militantes ou aos familiares de mortos e desapareci- 
dos, pois, como alerta Maria Rita Kehl (2004, p.237), "os acontecimentos traumáticos vividos por um grupo minoritário não podem ser excluídos da experiência coletiva da sociedade onde os grupos se inserem".

A desigualdade social exacerbada, o tratamento da violência de gênero como crime passional, o extermínio de jovens, na maioria negros, nas favelas brasileiras: não são poucos os exemplos para se mostrar a urgência em recuperar os projetos não realizados no passado e, numa perspectiva feminista, incorporá-los às lutas do presente na busca de transformação social.

O "ainda não estando as coisas" inspira-me a retomar os temas deste livro para continuar trabalhando com esse assunto inquietante, problemático, e fundamental para a compreensão e modificação da sociedade brasileira. Nessa esteira, finalizo meu texto com frases manifestadas por duas das depoentes do filme de Lúcia Murat, respectivamente Criméia e Jessie Jane:

"Eu estava disposta a pagar com a vida o preço da minha liberdade." "Eu não fiz parte deste acordo de silêncio." 


\section{REFERÊNCIAS BIBLIOGRÁFICAS}

ABREU, M. L. G. de. Feminismo no exílio: o círculo de mulheres brasileiras em Paris. Monografia de Graduação. Instituto de Filosofia e Ciências Humanas (IFCH), Unicamp, Campinas, 2006.

ADELMAN, M. Vozes, olhares e gênero no cinema. Cadernos de pesquisa e debate do Núcleo de Estudo de Gênero da UFPR, Curitiba, n.

2: Representações de Gênero no Cinema, 2003.

ADORNO, T.W. Educação e emancipação. São Paulo: Paz e Terra, 2000.

ALVES, B. M.; PITANGUY, J. O que é feminismo? São Paulo: Brasiliense, 2007.

ARANTES, M. A. de A. A subversão do eu. In: FREIRE, A.; ALMADA, I.; PONCE, J. A. de G. (Orgs.). Tiradentes, um presídio da ditadura: memórias de presos políticos. São Paulo: Scipione Cultural, 1997, p.441.

ARQUIDIOCESE DE SÃO PAULO. Brasil: Nunca Mais. São Paulo: Vozes, 1985.

AUGUSTO, H. Misturando erudito e popular, diretora filma musical na favela. Revista de Cinema, maio de 2008.

AUMONT, J. et. al. A estética do filme. Campinas: Papirus, 1995.

AUMONT, J.; MARIE, M. Dicionário teórico e crítico de cinema. Campinas: Papirus, 2003.

BEnjamin, W. Magia e Técnica, Arte e Política. São Paulo: Brasiliense, 1996. 
Charles Baudelaire: um lírico no auge do capitalismo. São Paulo: Brasiliense, 2004.

BERNARDET, J.-C. O que é cinema?. São Paulo: Brasiliense, 1985.

Cineastas e imagens do povo. São Paulo: Companhia da Letras. 2003.

BEZERRA, J. Lúcia Murat: o cinema militante. Revista de Cinema, v. 5 , n. 53 , abril de 2005 , p.18-23.

CADERNOS AEL. Mulher, Histórica e Feminismo. Campinas: IFCH/ Unicamp, n.3 e 4, 1995/96. . Tempo de Ditadura. Campinas: IFCH/ Unicamp, n.5, 2002. CANDIDO, A. De cortiço a cortiço. In: O discurso e a cidade. São Paulo: Duas cidades, 1993.

Dialética da malandragem. In: $O$ discurso e a cidade. São Paulo: Duas cidades, 1993.

Prefácio da 2a. edição. In: Formação da literatura brasileira. São Paulo: Martins, 1969.

CARDOSO, I. O arbítrio transfigurado em lei e a tortura polícia. In: FREIRE, Alípio; et. al. (Orgs.). Tiradentes, um presídio da ditadura: memórias de presos políticos. São Paulo: Scipione Cultural, 1997. Memória de 68: terror e interdição do passado. Tempo Social, São Paulo, n. 2, vol. 2, 1990, p.101-112.

CARVALHO, L. M. Mulheres que foram à luta armada. São Paulo: Globo, 1998.

CASSAL, A. de B. A solidão do herói: prisão, clandestinidade, exílio e outros isolamentos no cinema brasileiro. Monografia (Graduação em História). UERJ, Rio de Janeiro, 2001.

CHAUÍ, M. A tortura como impossibilidade da política. In: BRANCA, Eloysa (Org.). Seminário do Grupo Tortura Nunca Mais. Petrópolis: Editora Vozes, 1987, p.28-37.

COLLING, A. M. A resistência da mulher à ditadura militar no Brasil. Rio de Janeiro: Rosa dos Tempos, 1994.

As mulheres e a ditadura militar no Brasil. In: VIII Congresso Luso-Afro-Brasileiro de Ciências Sociais, 2004, Universidade de Coimbra, Coimbra, Portugal. Anais... Disponível em <http:// www.ces.uc.pt/LAB2004>. Acesso em junho/2008.

COMISSÃO DE FAMILIARES DE MORTOS E DESAPARECIDOS POLÍTICOS (Org.). Dossiê Ditadura: mortos e desaparecidos políticos no Brasil (1964-1985). São Paulo: Imprensa Oficial, 2009. 
CORREA, M. Do feminismo aos estudos de gênero no Brasil: um exemplo pessoal. Cadernos Pagu, 2001, n. 16, p.13-30.

CORSALETTE, C. Suicídio de mulher de Lamarca é improvável, diz laudo. Folha de S. Paulo, São Paulo, p.B9, 27 jun. 2005.

COSTA, A. de O. et. al. (Orgs.). Memória das mulheres do exílio. Rio de Janeiro: Paz e Terra, 1980.

CUNHA, R. de M. e. Memória dos ressentimentos: a luta armada através do cinema brasileiro dos anos 1980 e 1990. Dissertação (Mestrado em História), PUC - RJ, Rio de Janeiro, 2006.

DE LAURETIS, T. Imagenação. Cadernos de pesquisa e debate do Núcleo de Estudo de Gênero da UFPR, Curitiba, n. 2: Representações de Gênero no Cinema, 2003.

Tecnologia do gênero. In: BUARQUE DE HOLLANDA, $\mathrm{H}$.

(Org.). Tendências e impasses - o feminismo como crítica da cultura.

Rio de Janeiro: Rocco, 1994, p.237-238.

DESCARRIES, F. Teorias feministas: liberação e solidariedade no plural. In: Feminismos, teorias e perspectivas. Textos de história, UNB, vol. VII, n. 1/2, 2000.

ENTREVISTA COM LAURA MULVEY. Revista Estudos Feministas. Florianópolis, vol. 13, n. 2, 2005, p.351-362.

ESTEVES, F. C. Sob os sentidos do político: história, gênero e poder no cinema de Ana Carolina (Mar de rosas; Das tripas coração; Sonho de valsa - 1977/1986). Dissertação de Mestrado, Departamento de História, UFF, 2007.

FERREIRA, E. F. X. Mulheres, militância e memória. Rio de Janeiro: Fundação Getúlio Vargas, 1996.

FERREIRA, J.; REIS FILHO, D. A. (Orgs.). Revolução e democracia (1964-...). Rio de Janeiro: Civilização Brasileira, 2007 (Coleção As Esquerdas no Brasil, vol. 3).

FERRO, M. Cinema e História. Rio de Janeiro: Paz e Terra, 1992.

FICO, C. Além do golpe: versões e controvérsias sobre 1964 e a ditadura militar. Rio de Janeiro: Record, 2004, p.38.

FREIRE, A.; ALMADA, I.; PONCE, J. A. de G. (Orgs.). Tiradentes, um presídio da ditadura: memórias de presos políticos. São Paulo: Scipione Cultural, 1997.

GAGNEBIN, J. M. História e narração em Walter Benjamin. São Paulo: Perspectiva, 2007. 
Lembrar, escrever, esquecer. São Paulo: Editora 34, 2006. Seis teses sobre as "teses". CULT - Revista Brasileira de Cultura, São Paulo, 2009.

Verdade e memória do passado. Projeto História. PUC - SP, v. 17, nov/1998, p.213-222.

Walter Benjamin. São Paulo: Brasiliense, 1982.

GARCIA, M. A. O gênero na militância: notas sobre as possibilidades de uma outra história da ação política. Cadernos Pagu. Campinas, nos. 8/9, 1997, p.319-342.

GOLDBERG, A. Feminismo e autoritarismo: a metamorfose de uma utopia de liberação em ideologia liberalizante. Dissertação de Mestrado em Ciências Sociais, IFCS, UFRJ, Rio de Janeiro: 1987.

Feminismo no Brasil contemporâneo: o percurso intelectual de um ideário político. BIB, Rio de Janeiro, n. 28, $2^{\circ}$ sem. 1989, p. $42-70$.

GOMES, P. E. S. Cinema: trajetória no subdesenvolvimento. Rio de Janeiro: Paz e Terra, 1986.

JELIN, E. El género en las memorias de la represión política. Revista Mora. Buenos Aires, nº 7, 2001, p.128-137.

Los trabajos de la memoria. Espanha: Editorial Siglo XXI, 2002.

KAPLAN, E. Ann. A mulher e o cinema: os dois lados da câmera. Rio de Janeiro: Rocco, 1985.

KEHL, M. R. Ressentimento. São Paulo: Casa do Psicólogo, 2004.

KUSHNIR, B. Cães de guarda: jornalistas e censores, do AI-5 à Constituição de 1988. São Paulo: Boitempo Editorial, 2004.

MAGALHÃES, W. S. de. Filmes da luta armada: a reconstrução do regime militar no cinema. Mestrado em Comunicação, Universidade Federal Fluminense, Niterói, 2001.

MARX, K.; ENGELS, F. Manifesto do Partido Comunista. São Paulo: Boitempo Editorial, 1998.

MELO, E. I. Cultura juvenil feminista Riot Grrl em São Paulo. Dissertação de Mestrado. Campinas, IFCH, Unicamp, 2008.

MENEZES, P. R. A. de. Cinema: imagem e interpretação. Tempo Social-Revista de Sociologia da USP. São Paulo, n. 8, v. 2, outubro de 1996, p.83-104.

A questão do herói-sujeito em Cabra marcado para morrer, filme de Eduardo Coutinho. Tempo Social, USP, São Paulo, n. 6, vol. 1-2, 1994, p.107-126. 
Lês Maítres Fous, de Jean Rouch: questões epistemológicas da relação entre cinema documental e produção de conhecimento. Revista Brasileira de Ciências Sociais, vol. 22, n. 63, 2007, p.81-91. Representificação: as relações (im)possíveis entre cinema documental e conhecimento. Revista Brasileira de Ciências Sociais, v. 18, n. 51, 2003, p.87-98.

MILLARCH, A. Brasil, tortura e mulheres: duas visões de cineastas. Estado do Paraná. Paraná, 21 novembro 1989. Disponível em $<$ http://www.millarch.org/ler.php?id=3456>. Acesso em junho/ 2008.

O hino à vida de Lúcia Murat. Estado do Paraná. Paraná, 12 dezembro 1989. Disponível em: <http://www.millarch.org/ ler.php?id=4724>. Acesso em junho/2008.

MILlET, K. A política sexual. Portugal: Publicações Dom Quixote, 1974.

MORAES, J. Q. de. Liberalismo e ditadura no Cone Sul. Col. Trajetória, vol. 7, Campinas: IFCH/Unicamp, 2001.

MORAES, M. L. Q. de. A experiência feminista dos anos setenta. Araraquara: FCL/Unesp, 1990.

Dois estudos sobre cidadania. Campinas: IFCH/Unicamp, Col. Primeira Versão, vol. 109, 2002.

Memória Biográfica e Terrorismo de Estado: Brasile Chile. Campinas: IFCH/Unicamp, Col. Primeira Versão, vol. 96, 2001.

Feminismo, Movimentos de Mulheres e a (re)construção da democracia em três países da América Latina. Campinas: IFCH/ Unicamp, Col. Primeira Versão, vol. 121, 2003.

O feminismo político do século XX. Margem Esquerda - ensaios marxistas n. 9. São Paulo: Boitempo Editorial, junho de 2007, p.129-143.

Vinte anos de feminismo. Tese de Livre-Docência, IFCH, Unicamp, Campinas: 1996.

Impactos teóricos dos feminismos do século XX. In: SILVA, J. P. da (Org.). Por uma sociologia do século XX. São Paulo: Annablume, 2007, p.121-130.

MULVEY, L. Prazer visual e cinema narrativo. In: XAVIER, I. A experiência do cinema. Rio de Janeiro: Edições Graal, 1983.

MURAT, L. Mulheres torturadas [Que bom te ver viva]. Roteiro. Rio de Janeiro, mimeo, 1988. 
NAGIB, L. O cinema da retomada: depoimentos de 90 cineastas dos anos 90. São Paulo: Ed. 34, 2002.

A utopia no cinema brasileiro: matrizes, nostalgia, distopias. São Paulo: Cosac Naify, 2006.

NICHOLS, B. Introdução ao documentário. Campinas: Papirus, 2005.

NUMERATO, E.; OLIVEIRA, M. H. D. de. As musas do matinê. In: BRUSCHINI, M. C. A.; ROSEMBERG, F. Vivência. São Paulo: Brasiliense, 1980.

OBERTI, A.; PITTALUGA, R. Memorias en montaje: escrituras de la militancia y pensamientos sobre la historia. Argentina: El cielo por asalto, 2006.

OKIN, S. Gênero, o público e o privado. Revista Estudos Feministas, 2008, vol. 16, n. 2, p.305-332.

OLIVEIRA, E. M. de. Nosso corpo nos pertence: uma reflexão do feminismo pós-70. Labrys Estudos Feministas, v. 7, p.138-152, 2005. As relações entre mães e filhas(os) na solidão da tortura: reflexão de uma experiência. Trabalho apresentado no GT Família e Sociedade no XX Encontro da Anpocs, 1996.

OLIVEIRA, F. de. Crítica à razão dualista - o ornitorrinco. São Paulo: Boitempo Editorial, 2003.

PEREIRA, E. O filme-impacto do festival. Jornal da Tarde, 14 de junho de 1989.

PINTO, C. R. J. Uma história do feminismo no Brasil. São Paulo: Editora Fundação Perseu Abramo, 2003.

PIZOQUERO, L. M. Cinema e gênero: a trajetória de Gilda de Abreu. Dissertação de Mestrado, Instituto de Artes, Unicamp, 2006.

RAGO, M. O feminismo no Brasil: dos anos de chumbo à era global. Labrys Estudos Feministas, n. 3/4, 2003.

REIS, D. A.; RIDENTI, M.; MOTTA, R. P. S. (Orgs.). O golpe e a ditadura militar: quarenta anos depois (1964-2004). Bauru: Edusc, 2004.

REIS FILHO, D. A. et al. Versões e ficções: o seqüestro da história. São Paulo: Perseu Abramo, 1997.

REIS FILHO, D. A. Ditadura e sociedade: as reconstruções da memória. In: REIS, D. A.; et. al. (Orgs.). O golpe e a ditadura militar: quarenta anos depois (1964-2004). Bauru: Edusc, 2004, p.45.

Ditadura militar, esquerdas e sociedade. Rio de Janeiro: Zahar, 2005. 
Os muitos véus da impunidade: sociedade, tortura e ditadura no Brasil. Texto publicado no site Direitos Humanos e Cultura (DHnet). Disponível em: <http://www.dhnet.org.br/denunciar/ tortura/textos/aarao.htm>. Acesso em julho/2008.

RIDENTI, M. O fantasma da revolução brasileira. São Paulo: Ed. Unesp, 1993.

Em busca do povo brasileiro: artistas da revolução, do CPC à era da TV. Rio de Janeiro: Record, 2000.

As esquerdas em armas contra a ditadura (1964-1974), uma bibliografia. Cadernos Arquivo Edgard Leuenroth. Unicamp, Campinas, v. 8, n. 14-15, p.257-294, 2001.

As mulheres na política brasileira: os anos de chumbo. Tempo Social - Revista de Sociologia da USP. São Paulo, n. 2, vol. 2, 2 sem./ 1990, p.113-128.

Esquerdas revolucionárias armadas nos anos 1960-1970. In: FERREIRA, J.; REIS FILHO, D. A. (Orgs.). Revolução e democracia (1964-...). Rio de Janeiro: Civilização Brasileira, 2007 (Coleção As Esquerdas no Brasil, vol. 3).

Que história é essa? In: REIS FILHO, D. A. et al. Versões e ficções: o seqüestro da história. São Paulo: Perseu Abramo, 1997.

Resistência e mistificação da resistência armada contra a ditadura: armadilha para os pesquisadores. In: REIS, D. A.; RIDENTI, M.; MOTTA, R. P. S. (Orgs.). O golpe e a ditadura militar: quarenta anos depois (1964-2004). Bauru: Edusc, 2004.

ROVAI, M. L. Lindonéia (ou as trilhas da memória em dois curtas brasileiros). Texto publicado no site do Centro de Investigação e Estudos de Sociologia (CIES). Disponível em: <http://cies.iscte.pt/wp.jsp >. Acesso em outubro/2006.

Sociologia e cinema: reflexões sobre o gesto e o rosto na tela. Mimeo, trabalho apresentado no XXIX Encontro da Anpocs, 2005. Sobre Universidade em Crise e 15 Filhos. Mimeo, trabalho apresentado no XII Congresso Brasileiro de Sociologia, 2005.

SADER, E. Quando novos personagens entraram em cena-experiências e lutas dos trabalhadores na Grande São Paulo (1970-1980). Rio de Janeiro: Paz e Terra, 1988.

SALLES GOMES, P. E. Cinema: trajetória no subdesenvolvimento. Rio de Janeiro: Paz e Terra, 1980. 
SAPRIZA, G. Cuerpos bajo sospecha: un relato de la dictadura en Uruguay desde la memoria de las mujeres. Labrys Estudos Feministas, n. 15, 2009.

SARTI, C. O feminismo brasileiro desde os anos 1970: revisitando uma trajetória. Revista Estudos Feministas, v. 12, n. 2, Florianópolis, maio/ ago. 2004.

O início do feminismo sob a ditadura no Brasil: o que ficou escondido. In: XXI Congresso Internacional da Lasa - Latin American Studies Association. Anais... Chicago, Illinois, 1998. Disponível em <http://bibliotecavirtual.clacso.org.ar/ar/libros/lasa $>$. Acesso em junho/2008.

SCAVONE, L. A maternidade e o feminismo: diálogo com as ciências sociais. In: MORAES, M. L. Q. de (Org.). Desdobramentos do Feminismo. Cadernos Pagu, n. 16, 2001.

Dar a vida e cuidar da vida: feminismo e ciências sociais. São Paulo: Editora Unesp, 2004.

Estudos de gênero: uma sociologia feminista?. Revista Estudos Feministas, v. 16, p.173-186, 2008.

. Feminismo y Democracia en Brasil. Madrid: Akal, 2008, no prelo.

Gênero e políticas feministas, o lado sul. Estudos de Sociologia. Unesp/Araraquara, v. 13, p.157-158, 2008.

SCHWARZ, R. As idéias fora do lugar. In: Ao vencedor as batatas. São Paulo: Duas cidades, 1981.

A importação do romance e suas contradições em Alencar. In: Ao vencedor as batatas. São Paulo: Duas cidades, 1981. Cultura e política. São Paulo: Paz e Terra, 2005.

SCOTT, J. Deconstruir igualdad-diferencia: usos de la teoria posestructuralista para el feminismo. Feminaria, ano VII, n. 13, Buenos Aires, nov. 1994.

Experiência. In: SILVA, A. L. da; et al. (Orgs.). Falas de gênero. Ilhas de Santa Catarina: Mulheres, 1999.

Gênero: uma categoria útil de análise histórica. Educação $e$ Realidade, Porto Alegre, v. 16, n. 2, jul/dez, 1990.

SELIGMANN-SILVA, M. Adorno. São Paulo: Publifolha, 2003a. Introdução. In: História, memória, literatura: o testemunho na era das catástrofes. Campinas: Unicamp, 2003b. 
Reflexões sobre a memória, a história, o esquecimento. In: : História, memória, literatura: o testemunho na era das catástrofes. Campinas: Unicamp, 2003b.

. Introdução. In: Palavra e imagem, memória e escritura. Chapecó: Argos, 2006.

Escrituras da memória. In: Palavra e imagem, memória e escritura. Chapecó: Argos, 2006.

SILVA, M. A. M. da. Os escritores da guerrilha urbana: literatura de testemunho, ambivalência e transição política. São Paulo: Annablume/ FAPESP, 2008.

Prelúdios E Noturnos: ficções, revisões e trajetórias de um projeto político. Dissertação (Mestrado em Sociologia). IFCH / Unicamp, 2006.

SOIHET, R. História das mulheres e história de gênero: um depoimento. Cadernos Pagu, Campinas, n. 11, 1998, p.77-87.

Mulheres investindo contra o feminismo: resguardando privilégios ou manifestação de violência simbólica? Estudos de Sociologia. Unesp/Araraquara, v. 13, p.191-207, 2008.

SORLIN, P. Sociologia del cine: la apertura para la historia de mañana. México: Fondo de Cultura Econômica, 1985.

Indispensáveis e enganosas, as imagens, testemunhas da história. Estudos Históricos, Rio de Janeiro, vol. 7, n. 13, 1994.

SOUZA, M. L. R. Um estudo das narrativas cinematográficas sobre as ditaduras militares no Brasil (1964-1985) e na Argentina (1976-1983). Tese de Doutorado, Centro de Pesquisa e Pós-Graduação sobre as Américas, UNB, 2007.

TELES, M. A. de A. Breve história do feminismo no Brasil. São Paulo: Brasiliense, 2003.

TELES, E. Cine-bionarrativas: esquecimento e memória política. Olhar, São Carlos, vol. 9, 2004. Disponível em: <http://www.fflch.usp.br/ df/geral3/edson2.html>. Acesso em junho/2008.

TELLES, V. S. Movimentos sociais: reflexões sobre a experiência dos anos 70. In: WARREN, I. S.; KRISCHKE, P.(Orgs.). Uma revolução no cotidiano? Os novos movimentos sociais na América Latina. São Paulo: Brasiliense, 1986.

VANOYE, F.; GOLIOT-LÉTÉ, A. Ensaio sobre análise fílmica. Campinas: Papirus, 1994. 
VARIKAS, E. O pessoal é político: desventuras de uma promessa subversiva. Tempo, Rio de Janeiro, vol. 2, n. 3, 1996, p.59-80.

XAVIER, I. O cinema brasileiro moderno. São Paulo: Paz e Terra, 2001. Cinema político e gêneros tradicionais: a força e os limites da matriz melodramática. Revista USP, São Paulo, n. 19, set/nov 1993, p.114-141.

- O discurso cinematográfico: a opacidade e a transparência. Rio de Janeiro: Paz e Terra, 1977.

A ilusão do olhar neutro e banalização. Revista Praga, n. 3, São Paulo: Hucitec, 1997, pp.141-153.

Documentário e afirmação do sujeito: Eduardo Coutinho, na contramão do ressentimento. In: SOCINE - Sociedade Brasileira de Estudos de Cinema. Estudos Socine de cinema ano IV. São Paulo: Panorama, 2003, p.163-171.

Figuras do ressentimento no cinema brasileiro dos anos 90. In: SOCINE - Sociedade Brasileira de Estudos de Cinema. Estudos Socine de cinema 2000. Porto Alegre: Sulina, 2001, p.78-98. 


\section{Anexos}

\section{Bom burguês, 0}

Tempo de duração: 99 minutos

Ano de lançamento (Brasil): 1983

Direção: Oswaldo Caldeira

Roteiro: Doc Comparato e Oswaldo Caldeira

Produção: Oswaldo Caldeira

Produção Executiva: Paulo Thiago

Assistente de direção: Nei Costa Santos, Carlos del Pino e Sandra Werneck

Argumento: Leopoldo Serran e Oswaldo Caldeira

Direção de produção: Ângelo Gastal e Alceu Massari

Assistente de produção: Paulo Dubois, Mercedes Viegar

Coprodução: Encontro Produções Cinematográficas

Música e arranjos: Paulo Moura

Mixagem: José Luiz Sasso

Som guia: Luiz Fernando Almeida

Fotografia: Antônio Penido

Fotografia de cena: Vera Baumgarten

Cenografia e figurinos: Paulo Chada

Montagem: Gilberto Santeiro

Elenco: JoséWilker, Betty Faria, Jardel Filho, Christiane Torloni, Anselmo Vasconcelos, Nicole Puzzi, Nelson Dantas, Jofre Soares, Nelson Xavier, Paulo Porto, Emanuel Cavalcanti, Fábio Junqueira, Ivan de Almeida, Carlos Wilson, Adriana Figueiredo, Celso Faria. 


\section{Lamarca}

Tempo de duração: 130 minutos

Ano de lançamento (Brasil): 1994

Direção: Sérgio Rezende

Roteiro: Alfredo Oroz e Sérgio Rezende, baseado em livro de Emiliano José

Oldack Miranda

Produção: Mariza Leão

Fotografia: Antonio Luis Soares

Montagem: Isabelle Rathery

Música: David Tygel

Diretor de arte: Clóvis Bueno

Elenco: Paulo Betti, Carla Camurati, Eliezer de Almeida, Deborah Evelyn, Carlos Zara, José de Abreu.

\section{Que bom te ver viva}

Tempo de duração: 110 minutos

Ano de produção: 1988

Ano de lançamento (Brasil): 1989

Direção: Lúcia Murat

Roteiro: Lúcia Murat

Produção executiva: Lúcia Murat

Fotografia: Walter Carvalho

Montagem: Vera Freire

Som direto: Heron Alencar

Diretor-assistente: Adolfo Orico Rosenthal

Direção de produção: Kátia Cop e Maria Helena Nascimento

Cenografia e figurino: Beatriz Salgado

Música original: Fernando Moura

Trilha sonora: Aécio Flávio

Distribuidora Nacional: Taiga Filmes e Vídeo

Distribuidora Internacional para os EUA: Woman Make Movies

Elenco: Irene Ravache.

\section{Que é isso, companheiro?, 0}

Tempo de duração: 105 minutos

Ano de lançamento (Brasil): 1997 
Estúdio: Luiz Carlos Barreto Produções Cinematográficas; Filmes do Equador; Pandora Cinema; Quanta; Sony Corporation of América

Distribuição: Miramax Films, Riofilmes

Direção: Bruno Barreto

Roteiro: Leopoldo Serran, baseado em livro de Fernando Gabeira

Produção: Lucy Barreto e Luiz Carlos Barreto

Música: Stewart Copeland

Direção de fotografia: Félix Monti

Desenho de produção: Marcos Flaksman e Alexandre Meyer

Figurino: Emilia Duncan

Edição: Isabelle Rathery

Efeitos especiais: DVC Arte \& Técnica, Farjalla

Elenco: Alan Arkin, Fernanda Torres, Pedro Cardoso, Luiz Fernando Guimarães, Cláudia Abreu, Nélson Dantas, Matheus Natchergaele, Marco Ricca, Maurício Gonçalves, Caio Junqueira, Selton Mello, Du Moscovis, Caroline Kava, Fernanda Montenegro, Lulu Santos, Alessandra Negrini, Antônio Pedro, Milton Gonçalves, Othon Bastos.

\section{Pra frente, Brasil}

Tempo de duração: 104 minutos

Ano de lançamento (Brasil): 1983

Estúdio: Embrafilme / Produções Cinematográficas R. F. Farias Ltda.

Distribuição: Embrafilme

Direção: Roberto Farias

Roteiro: Roberto Farias, baseado em argumento de Reginaldo Faria e Paulo Mendonça

Produção: Rogério Farias

Música: Egberto Gismonti

Fotografia: Dib Lufti e Francisco Balbino Nunes

Direção de arte: Maria Tereza Amarante

Figurino: Maria Tereza Amarante e Mara Ache

Edição: Roberto Farias e Mauro Farias

Elenco: Neuza Amaral, Expedito Barreira, Rogério Blum, Dennis Bourke, Renato Coutinho, Newton Couto, Ivan Cândido, Antônio Fagundes, Lui Farias, Irma Alvarez, Maurício Farias, Reginaldo Faria, Odenir Fraga, Cláudio Marzo, Hélio Mascarenhas, Flávio Migliaccio, Elizabeth Savalla, Carlos Zara, Natália do Valle. 
SOBRE O LIVRO

Formato: $14 \times 21 \mathrm{~cm}$

Mancha: $23,7 \times 42,5$ paicas

Tipologia: Horley Old Style 10,5/14

Papel: Offset $75 \mathrm{~g} / \mathrm{m}^{2}$ (miolo)

Cartão Supremo $250 \mathrm{~g} / \mathrm{m}^{2}$ (capa)

$1^{\text {a }}$ edição: 2010

\section{EQUIPE DE REALIZAÇÃO}

Coordenação Geral

Marcos Keith Takahashi 


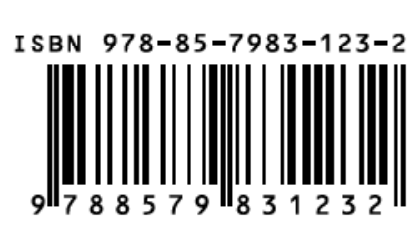

CULTURA

$\frac{\text { ACADÊMICA }}{\varepsilon d i t o r a}$ 